\title{
ESTUDO DA REFLETÂNCIA E SUA INFLUÊNCIA NO COMPORTAMENTO TÉRMICO DE TINTAS REFLETIVAS E CONVENCIONAIS DE CORES CORRESPONDENTES
}

Dissertação apresentada ao Departamento de Engenharia de Construção Civil e Urbana da Escola Politécnica da Universidade de São Paulo.

Paula Ikematsu

SÃO PAULO

DEZEMBRO, 2007 


\title{
PAULA IKEMATSU
}

\section{ESTUDO DA REFLETÂNCIA E SUA INFLUÊNCIA NO COMPORTAMENTO TÉRMICO DE TINTAS REFLETIVAS E CONVENCIONAIS DE CORES CORRESPONDENTES}

\author{
Dissertação apresentada à Escola \\ Politécnica da Universidade de São Paulo \\ para obtenção do título de Mestre em \\ Engenharia de Construção Civil e Urbana. \\ Área de concentração: \\ Engenharia de Construção Civil e Urbana \\ Orientadora: \\ Prof. Dra. Kai Loh
}

\author{
São Paulo \\ Exemplar Original: 2007 \\ Exemplar Revisado: 2007
}


Este exemplar foi revisado e alterado em relação à versão original, sob responsabilidade única do autor e com a anuência de seu orientador.

São Paulo, de dezembro de 2007.

Assinatura do autor

Assinatura do orientador

FICHA CATALOGRÁFICA

Ikematsu, Paula

Estudo da refletância e sua influência no comportamento térmico de tintas refletivas e convencionais de cores correspondentes / P. Ikematsu. -- ed.rev. -- São Paulo, 2007.

$117 \mathrm{p}$.

Dissertação (Mestrado) - Escola Politécnica da Universidade de São Paulo. Departamento de Engenharia de Construção Civil.

1.Tintas 2.Materiais de cobertura 3.Refletância 4.Comportamento térmico I.Universidade de São Paulo. Escola Politécnica. Departamento de Engenharia de Construção Civil Il.t. 
Não esquenta, tudo reverterá para o bem! Os anjos nos protegem...

(eu acredito porque foi minha mãe que disse) 


\section{$\Delta$ gradecimentos}

Agradeço a minha família que sempre acreditou em mim e nos meus sonhos.

A minha querida orientadora $\mathrm{Dr}^{\mathrm{a}}$. Kai Loh muito obrigada pelos conhecimentos compartilhados (que resultaram nesta dissertação), pelos conselhos (que eu vou levar para a minha vida toda) e pelas broncas (que eu prefiro esquecer). Obrigada por tudo!

$A \mathrm{Dr}^{\mathrm{a}}$. Neide Sato, obrigada de coração pela sua generosidade comigo. Esta dissertação não seria nem metade do que "é" sem a sua ajuda.

Aos meus queridos e queridas aqui da Poli: Clebão, Mário, Engrácia, Patty, Luis, Edson, Galera do laboratório! Enfim... A todos vocês, obrigada pela ajuda braçal e laboratorial, pelos momentos de terapia, pelos conselhos... Levarei vocês para sempre no meu coração.

Aos meus amigos que sempre me deram a maior força neste mestrado, mesmo quando eu recusava alguma balada ou um boteco por causa dele...

A Luckscolor por ter me fornecido as tintas para este trabalho, ao IAG - USP pelos dados metereológicos e ao Prof. Dr. Racine por compartilhar comigo o seu precioso espectrofotômetro.

Agradeço ao Conselho Nacional de Desenvolvimento Científico e Tecnológico (CNPq) pela bolsa de mestrado e a Escola Politécnica da Universidade de São Paulo por ter cedido o espaço para a realização da minha pesquisa.

Ai... Nem acredito que terminei... Graças a Deus! E a Paula Ikematsu!

Obrigada a todos! 


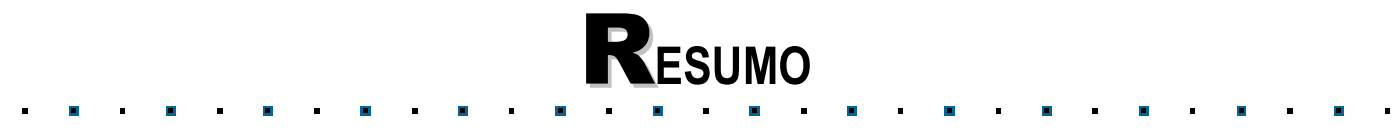

IKEMATSU, P. Estudo da refletância e sua influência no comportamento térmico de tintas refletivas e convencionais de cores correspondentes. 2007. Dissertação (mestrado) - Departamento de Engenharia de Construção Civil da Escola Politécnica, Universidade de São Paulo. São Paulo, 2007.

O principal objetivo deste estudo foi avaliar a refletância e sua influência no comportamento térmico de tintas refletivas e tintas convencionais aplicadas em telhas de fibrocimento para cobertura de habitações brasileiras.

Foram realizados ensaios em laboratório de determinação de cor e de brilho por medida instrumental e determinação da refletância por análise espectrofotométrica em películas. Para o estudo do comportamento térmico foram realizados ensaios de simulação em laboratório com corpos-de-prova expostos à radiação infravermelha emitida por lâmpadas e de exposição à radiação solar em campo através de protótipos com monitorização da temperatura durante as exposições.

Os resultados dos ensaios de determinação de cor e de brilho mostraram que as pinturas refletivas e convencionais realmente apresentaram cores correspondentes. Os resultados de refletância mostraram que as pinturas refletivas apresentaram valores de refletância superiores em relação às tintas convencionais, o que foi comprovado pela temperatura medida nos ensaios de exposição à radiação infravermelha e radiação solar.

A conclusão do estudo é que as tintas refletivas têm potencial para redução da temperatura superficial da telha de fibrocimento e que é necessária uma continuidade do estudo de durabilidade e do desempenho térmico de tintas refletivas coloridas.

Palavras-chave: tintas, tintas refletivas, refletância, desempenho térmico, tintas coloridas, análise espectrofotométrica. 


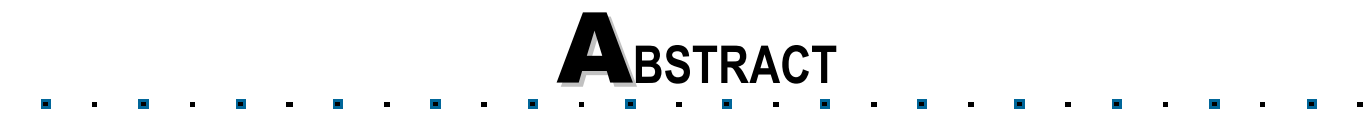

IKEMATSU, P. Influence of reflectivity on the thermal behavior of color-matched reflective and conventional paints. 2007. Thesis (Master's Degree) - Department of Civil Construction Engineering of Escola Politécnica, Universidade de São Paulo, São Paulo, 2007.

The main purpose of this study was to investigate the effect of reflective colored paints and conventional colored paints applied on fiber cement corrugated roofing sheets, proving whether both type of paints can present different reflection characteristics in the infrared solar radiation and high thermal performance.

Color and gloss were measured by instrumental methods and reflectivity (reflection coefficient) was measured using spectrophotometers equipped with integrating spheres in "free" paint films. In order to investigate the thermal performance of reflective and conventional paints, simulation tests were performed in laboratory by IR lamps using fiber cement specimens and in field by exposure solar radiation using prototypes with temperature monitoring.

The results showed that the reflective paints present higher reflectivity and better thermal performance than the conventional paint, independently of the color.

The results showed that the reflective paints present potential to reduce superficial temperature of fiber cement corrugated roofing sheets. It is necessary to continue the reflective colored paints study on durability and thermal performance by exposure tests.

Keywords: paints, reflective paints, reflectivity, albedo, thermal performance, spectroscopy analysis. 


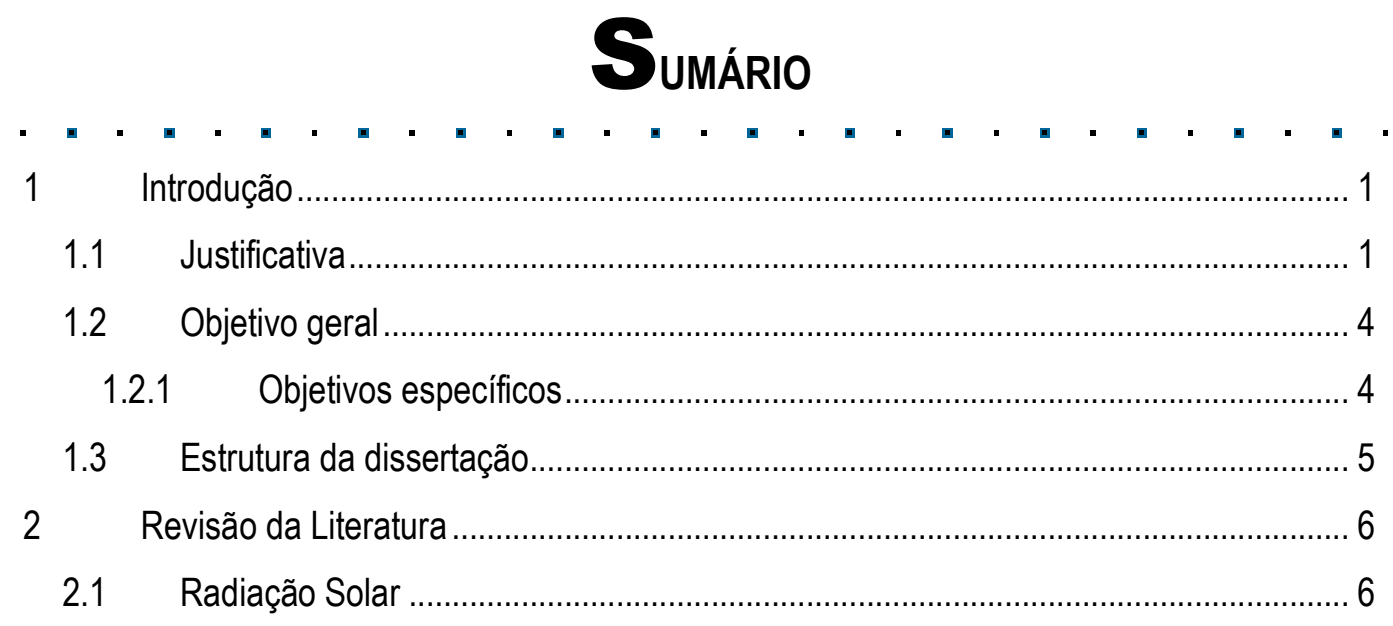

2.1.1 A influência da radiação solar no conforto térmico dos usuários .................... 10

2.1.2 Estudos para melhoria do conforto térmico ................................................ 14

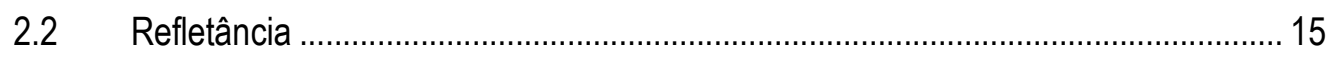

2.2.1 Comportamento refletivo dos materiais .................................................... 16

2.2.2 Fatores que interferem na refletância dos materiais....................................... 17

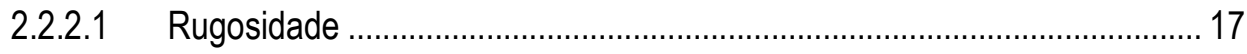

2.2.2.2 Exposição às variáveis ambientais ......................................................... 17

2.2.3 Correlação da refletância com o desempenho térmico ................................... 19

2.3 Comportamento térmico de materiais de cobertura................................................ 21

2.3.1 Influência das cores dos materiais de cobertura no desempenho térmico..... 22

2.3.2 Transferência de calor ................................................................................. 24

2.3.2.1 Transferência de calor em coberturas ..................................................... 26

2.3.3 Tipos de isolantes térmicos .................................................................... 28

2.3.3.1 Revestimentos refletivos: tintas refletivas ................................................ 29

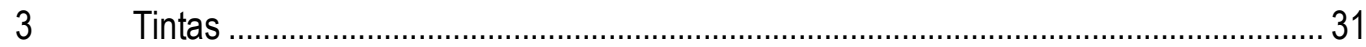

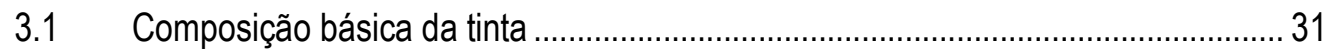

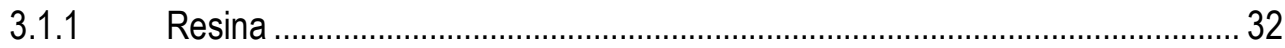

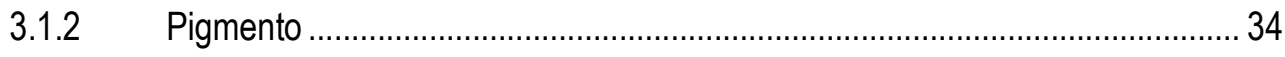

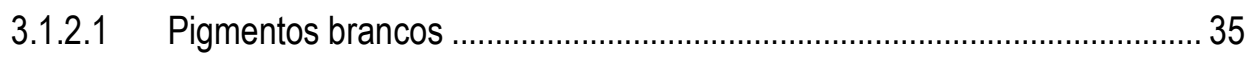

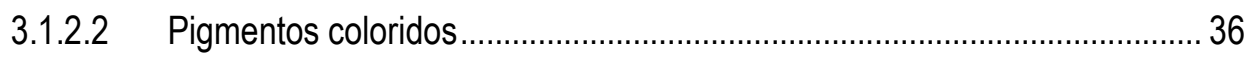

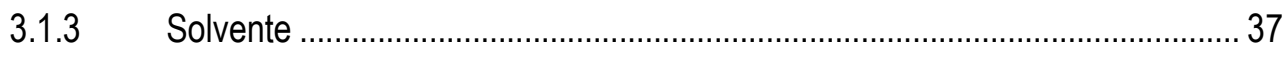

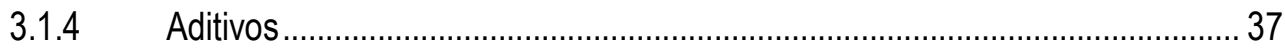

3.1.5 Fração volumétrica de pigmentos (PVC) ........................................................ 38 


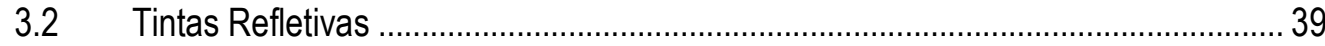

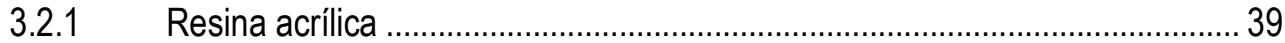

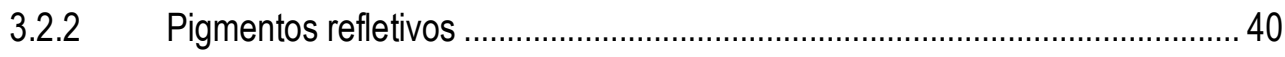

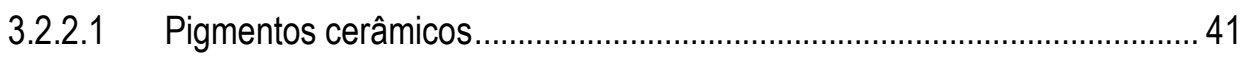

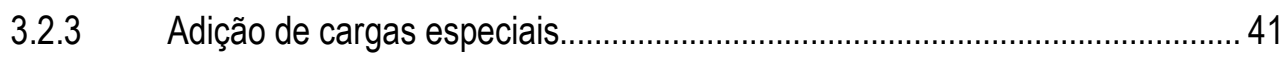

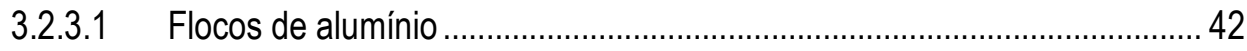

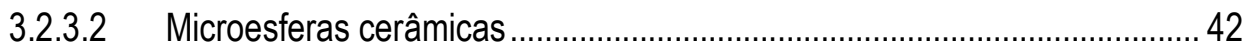

3.2.4 Benefícios da utilização de tintas refletivas................................................. 43

$4 \quad$ Planejamento Experimental, Materiais e Métodos …............................................... 45

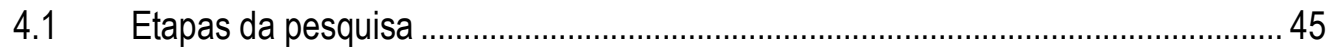

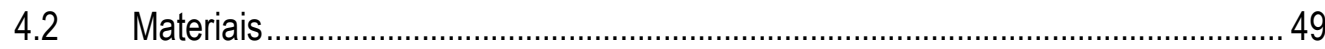

4.2.1 Tintas e telha de fibrocimento .................................................................. 49

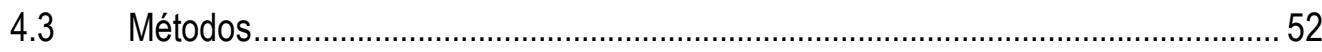

4.3.1 Determinação da cor por medida instrumental .......................................... 52

4.3.1.1 Definições ....................................................................................... 53

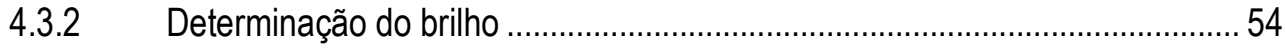

4.3.3 Determinação da refletância por espectrofotometria .................................... 55

4.3.3.1 Parâmetros para ensaio de refletância ........................................................57

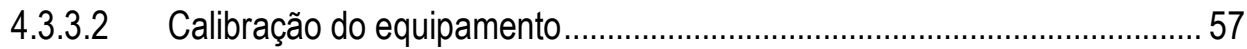

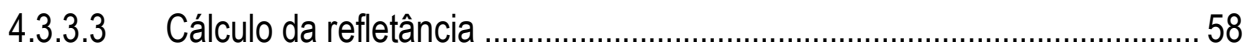

4.3.4 Efeito da radiação infravermelha na temperatura de corpos-de-prova........... 59

4.3.5 Ensaio em campo: efeito da radiação solar na temperatura de protótipos

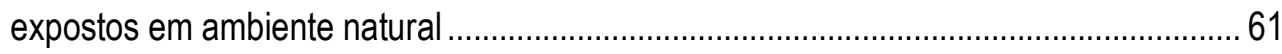

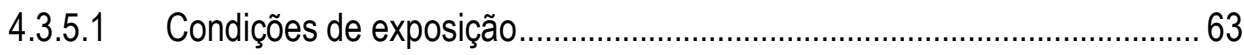

4.3.5.2 Exposição natural na Estação de Envelhecimento Natural de São Paulo. 65

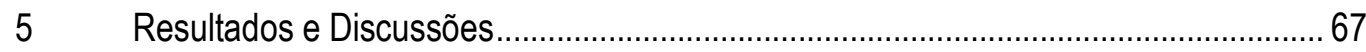

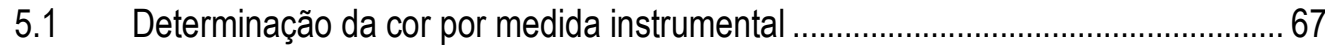

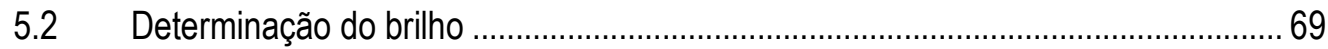

5.3 Determinação da refletância por espectrofotometria ...............................................6 69

5.3.1 Películas de tinta e telha de fibrocimento.......................................................6 69

5.3.2 Tinta de cor branca..................................................................................... 72

5.3.2.1 Película de cor branca .............................................................................. 72 
5.3.2.2 Telha de fibrocimento com pintura branca............................................... 72

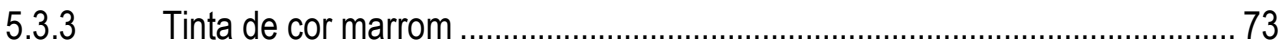

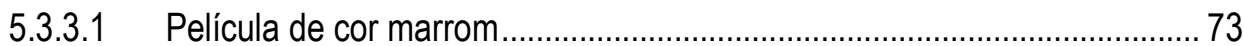

5.3.3.2 Telha de fibrocimento com pintura marrom ............................................... 74

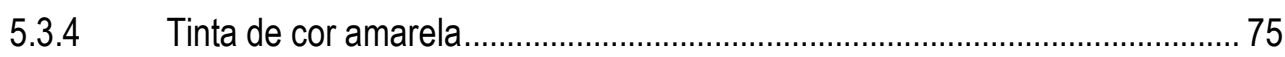

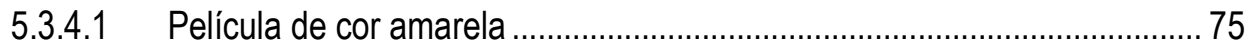

5.3.4.2 Telha de fibrocimento com pintura amarela ............................................ 76

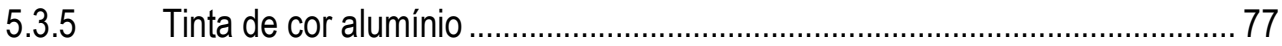

5.3.5.1 Película de cor alumínio........................................................................... 77

5.3.5.2 Telha de fibrocimento com pintura refletiva alumínio ................................... 78

5.3.6 Tinta refletiva de cor branca com cargas especiais ........................................ 79

5.3.6.1 Película de cor branca ......................................................................... 79

5.3.6.2 Telha de fibrocimento com pintura branca refletiva ................................... 80

5.4 Efeito da radiação infravermelha na temperatura dos corpos-de-prova................... 81

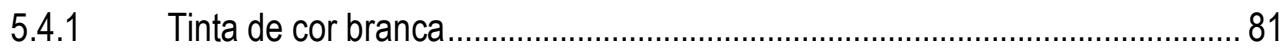

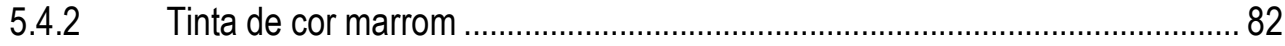

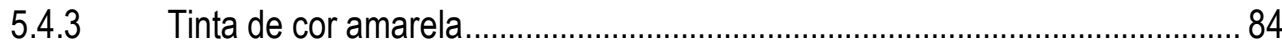

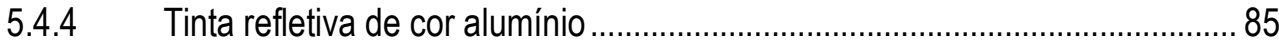

5.4.5 Tinta refletiva de cor branca com adição de cargas especiais........................ 86

5.5 Ensaio em campo: efeito da radiação solar na temperatura de protótipos expostos

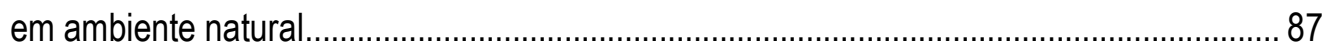

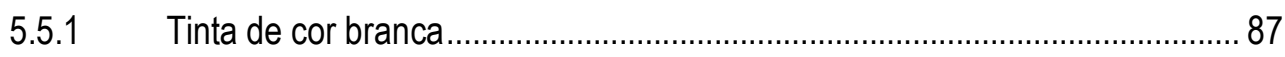

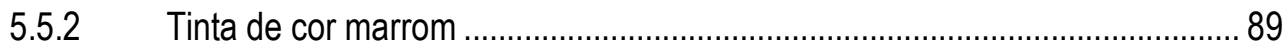

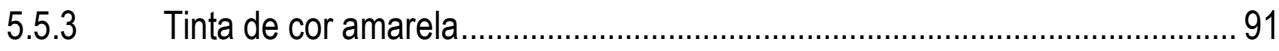

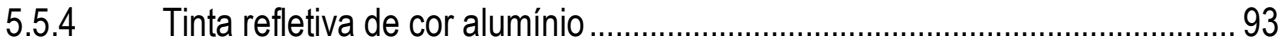

5.5.5 Tinta refletiva de cor branca com adição de cargas especiais......................... 95

5.6 Influência da formulação das tintas no desempenho térmico ................................ 97

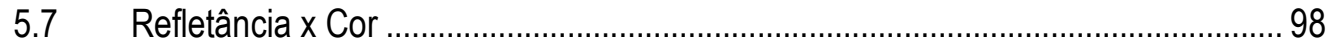

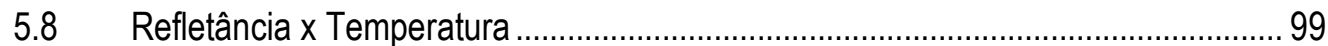

5.9 Avaliação com base nos critérios da "Energy Star ${ }^{\circledR}$ Roofs Products"..................... 102

5.9.1 Películas de tinta isoladas $x$ corpos-de-prova pintados............................... 102

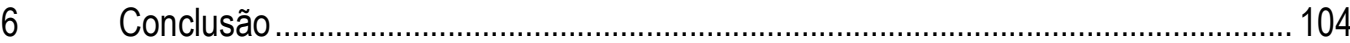




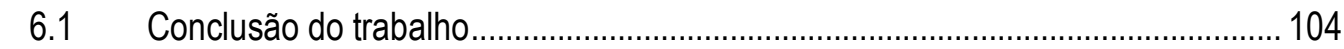

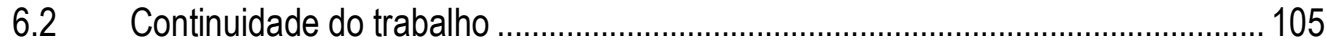

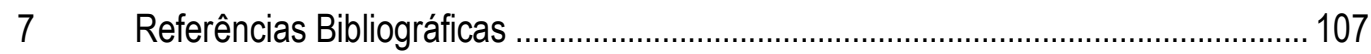




\section{LISTA de figuras}

Figura 2.1 Espectro de radiação eletromagnética........................................................................

Figura 2.2: Espectro de radiação solar................................................................................. 7

Figura 2.3: Distribuição percentual da radiação solar incidente................................................ 9

Figura 2.4: Esquema distribuição da radiação solar em uma edificação.................................... 10

Figura 2.5: Perfil de uma cidade com microclima. ............................................................... 11

Figura 2.6: Microclimas da cidade de São Paulo.................................................................... 12

Figura 2.7: Mapa da cidade de São Paulo, caracterizando regiões onde ocorrem as ilhas de calor. 14

Figura 2.8: Esquemas de refletância especular e difusa ......................................................... 16

Figura 2.9: Benefícios de uma manutenção regular das tintas refletivas aplicadas à materiais

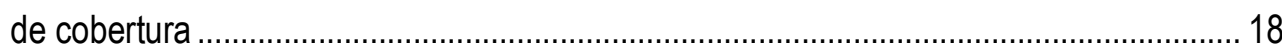

Figura 2.10: llustração da radiação solar em uma cobertura com alta refletividade (a) e com baixa refletividade (b) à radiação solar ................................................................... 23

Figura 2.11: Esquemas simplificados de mecanismos de transferência de calor...................... 24

Figura 2.12: Esquema do mecanismo de condução................................................................ 25

Figura 2.13: Esquema do mecanismo de convecção ............................................................. 25

Figura 2.14: Esquema do mecanismo de irradiação................................................................ 26

Figura 2.15: Representação de trocas de calor em um telhado............................................... 28

Figura 2.16: Propriedades radiantes no espectro da radiação solar e do infravermelho de materiais de construção. ....................................................................................... 30

Figura 3.1: Ambientes de uma edificação com diferentes tipos de acabamento para tintas.... 31

Figura 3.2: Exemplo de composição básica de tintas à base solvente e base água................. 32

Figura 3.3: Monômero acrilato e polímero do poliacrilato.......................................................... 33

Figura 3.4: Reflexão da luz a partir das partículas de pigmentos............................................. 36

Figura 3.5: Prisma de cor ......................................................................................... 37

Figura 3.6: Tinta com PVC baixo e alto......................................................................... 39

Figura 3.7: Foto de câmera infravermelha do pigmento convencional e refletivo de cor marrom. 
Figura 3.8: Esquema das camadas da pintura contendo flocos de metal (Adaptado de Smith,

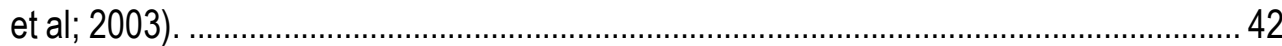

Figura 3.9: Microesfera cerâmica de alta resistência............................................................... 43

Figura 3.10: Esquema de corte do sistema refletivo, com destaque para a disposição das

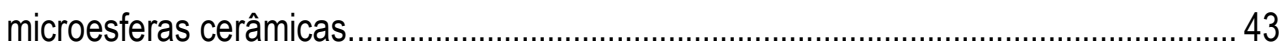

Figura 3.11: Gráfico de variação de temperatura ao longo do tempo......................................... 44

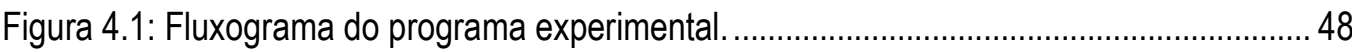

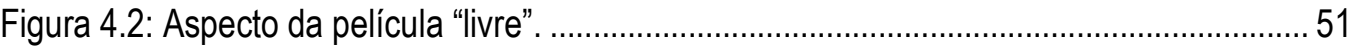

Figura 4.3: Telhas de fibrocimento após receberem pintura. .................................................... 52

Figura 4.4: Esquema de produção dos corpos-de-prova para o ensaio de refletância. ............52

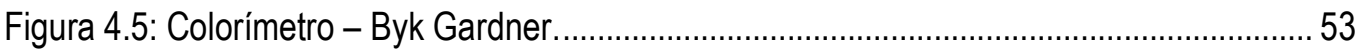

Figura 4.6: Gráfico do CIE L*a*b*, sistema de cores desenvolvido para quantificar cores. ..... 54

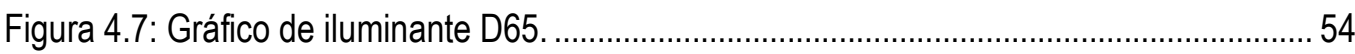

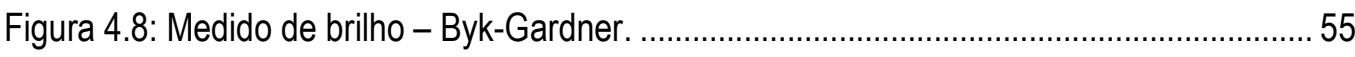

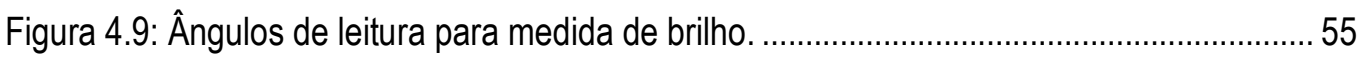

Figura 4.10: Espectrofotômetro UV 3101PC com esfera integradora - Shimadzu....................56

Figura 4.11: Esquema de medição de amostra opaca usando o método de esfera integradora.

Figura 4.12: Sistema ótico da medição difusa (Adaptado do Manual de Instruções do

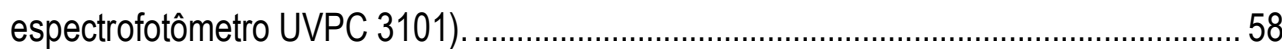

Figura 4.13: Diagrama para o cálculo de área integrada.......................................................58

Figura 4.14: Esquema final do equipamento adaptado para exposição à radiação

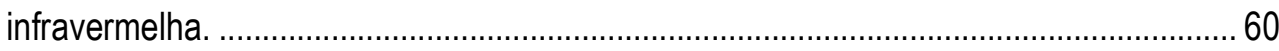

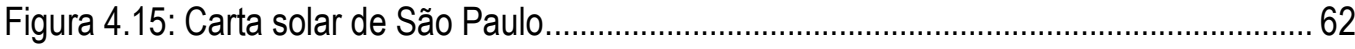

Figura 4.16: Layout e foto do protótipo para exposição natural. ............................................... 63

Figura 4.17: Pluviógrafo de Hellmann e pluviômetros Ville de Paris e Paulista. ......................... 64

Figura 4.18: Psicrômetro de aspiração tipo Assmann com motor elétrico................................... 64

Figura 4.19: Higrógrafo dotado de harpa de fio de cabelo, com rotação diária. ....................... 65

Figura 4.20: Actinógrafo bimetálico instalado no alto da torre da Estação................................. 65

Figura 4.21: Vista da estação de exposição no Departamento de Construção Civil. ................ 66

Figura 5.1: Distribuição de cores no Gráfico do CIE L*a*b* ...................................................... 67

Figura 5.2: Espectro de todas as películas de tintas estudadas............................................. 70 


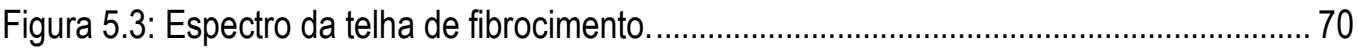

Figura 5.4: Espectro das tintas de cor branca (T1 e T4) ........................................................ 72

Figura 5.5: Espectro comparativo da T1 (refletiva branca) e da T4 (tinta convencional)

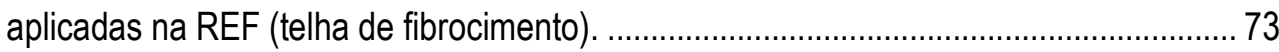

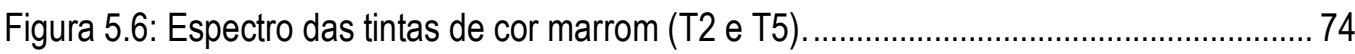

Figura 5.7: Espectro comparativo da T2 (refletiva marrom) e da T5 (convencional marrom)

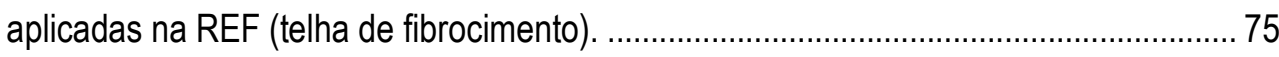

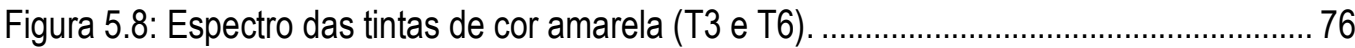

Figura 5.9: Espectro comparativo da T3 (refletiva amarela) e da T6 (convencional amarela) aplicadas na REF (telha de fibrocimento). ...................................................................... 77

Figura 5.10: Espectro das tintas de cor alumínio (T7 e T8).................................................... 78

Figura 5.11: Espectro comparativo da T7 (refletiva alumínio nacional) e da T8 (refletiva alumínio internacional) aplicadas na REF (telha de fibrocimento).................................. 79

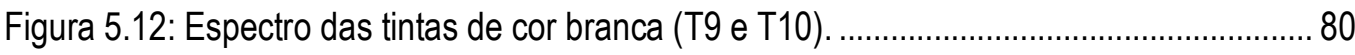

Figura 5.13: Espectro comparativo da T9 (refletiva branca com esferas de vidro ocas) e da T10 (refletiva branca com microesferas cerâmicas) aplicadas na REF (telha de

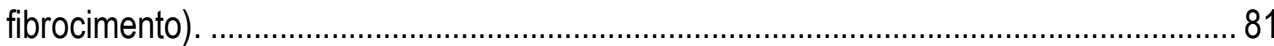

Figura 5.14: Gráfico de temperaturas da tinta branca refletiva (REF + T1) e convencional (REF + T4) aplicadas na telha de fibrocimento (REF). 82

Figura 5.15: Gráfico de temperaturas da tinta marrom refletiva (REF + T2) e convencional (REF + T5) aplicadas na telha de fibrocimento (REF)

Figura 5.16: Gráfico de temperaturas da tinta amarela refletiva (REF + T3) e convencional $(\mathrm{REF}+\mathrm{T6})$ aplicadas na telha de fibrocimento (REF) .............................................. 84

Figura 5.17: Gráfico de temperaturas da tinta alumínio refletiva nacional $(R E F+T 7)$ e internacional (REF + T8) aplicadas na telha de fibrocimento (REF) 85

Figura 5.18: Gráfico de temperaturas da tinta branca refletiva com microesferas de vidro (REF + T9) e microesferas cerâmicas (REF + T10) aplicadas na telha de fibrocimento (REF).86

Figura 5.19: Gráfico das temperaturas da superfície das coberturas dos protótipos REF, P1 e P4 e do ar externo. 88

Figura 5.20: Gráfico da diferença de temperatura superficial entre o protótipo de REF e os protótipos $\mathrm{P} 1$ e $\mathrm{P} 4$ 
Figura 5.21: Gráfico das temperaturas da superfície das coberturas dos protótipos REF, P2 e

P5 e do ar externo.

Figura 5.22: Gráfico da diferença de temperatura superficial entre o protótipo REF e os protótipos P2 e P5.

Figura 5.23: Gráfico das temperaturas da superfície das coberturas dos protótipos REF, P3 e

P6 e do ar externo. 92

Figura 5.24: Gráfico da diferença de temperatura superficial entre o protótipo REF e os protótipos P3 e P6. 92

Figura 5.25: Gráfico das temperaturas da superfície das coberturas dos protótipos REF, P7 e P8 e do ar externo. 94

Figura 5.26: Gráfico da diferença de temperatura superficial entre o protótipo REF e os protótipos P7 e P8. .94

Figura 5.27: Gráfico das temperaturas da superfície das coberturas dos protótipos REF, P9 e P10 e do ar externo. 96

Figura 5.28: Gráfico da diferença de temperatura superficial entre o protótipo REF e os protótipos P9 e P10. 96

Figura 5.29: Refletância total (\%) das películas de tinta....................................................... 98

Figura 5.30: Correlação entre luminosidade e refletância total (\%) das películas de tinta....... 99 Figura 5.31: Gráfico de correlação entre a diferença de temperatura da telha de fibrocimento (REF) e dos corpos-de-prova e protótipos pintados com as tintas do estudo. 100

Figura 5.32: Gráfico comparativo da refletância das películas das tintas do estudo. 102

Figura 5.33: Gráfico comparativo da telha de fibrocimento pintada com as tintas do estudo. 103 


\section{LISTA DE TABeLAs}

Tabela 2.1:Exemplos de diferença das temperaturas devido ao efeito das ilhas de calor. ....... 14

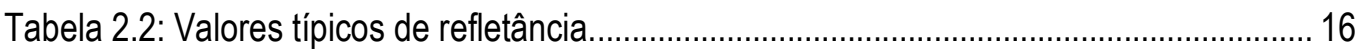

Tabela 2.3: Composição da superfície estimada de Sacramento - Califórnia .......................... 21

Tabela 3.1: Componentes básicos da tinta e aditivos utilizados na formulação. ........................ 38

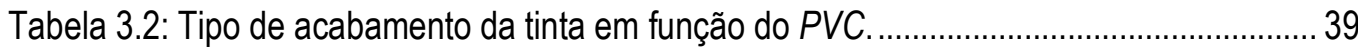

Tabela 4.1: Ensaios do programa experimental com os respectivos materiais de estudo....... 48

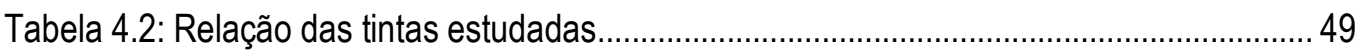

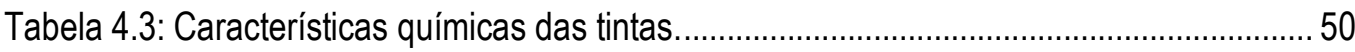

Tabela 4.4: Composição básica das tintas......................................................................... 50

Tabela 4.5: Relação dos protótipos utilizados no ensaio em campo .........................................52

Tabela 4.6: Resultados dos testes de temperatura............................................................. 59

Tabela 4.7: Valores correspondentes ao período 1 e ao período 2 para a freqüência de

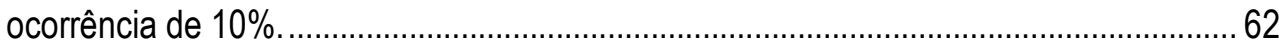

Tabela 5.1: Média das leituras de cor das películas de tinta estudadas. ................................... 68

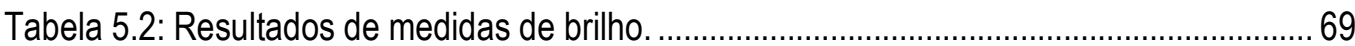

Tabela 5.3: Resultados médios de refletância das películas de todas as tintas estudadas..... 71

Tabela 5.4: Resultados médios de refletância das películas das tintas de cor branca.............. 72

Tabela 5.5: Resultados médios de refletância das tintas de cor branca aplicadas na telha de

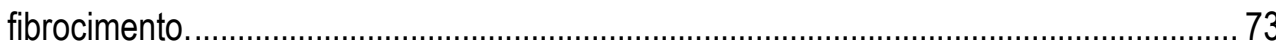

Tabela 5.6: Resultados médios de refletância das películas das tintas de cor marrom. ...........74

Tabela 5.7: Resultados médios de refletância das tintas de cor marrom aplicadas na telha de

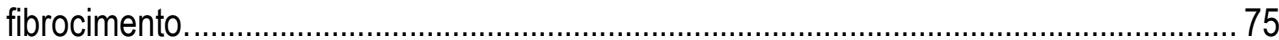

Tabela 5.8: Resultados médios de refletância das películas das tintas de cor amarela........... 76

Tabela 5.9 Resultados médios de refletância das tintas de cor amarela aplicadas na telha de fibrocimento.

Tabela 5.10: Resultados médios de refletância das películas das tintas de cor alumínio......... 78

Tabela 5.11: Resultados médios de refletância das tintas de cor alumínio aplicadas na telha de fibrocimento. 
Tabela 5.12: Média das leituras de refletância das películas das tintas de cor branca (com adição de cargas especiais)

Tabela 5.13: Média das leituras de refletância das tintas refletivas de cor branca aplicadas na

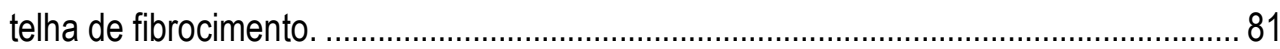

Tabela 5.14: Temperaturas máximas e médias das tintas de cor branca................................. 82

Tabela 5.15: Temperaturas máximas e médias das tintas de cor marrom................................ 83

Tabela 5.16: Temperaturas máximas e médias das tintas de cor amarela............................... 84

Tabela 5.17: Temperaturas máximas e médias das tintas de cor alumínio................................ 85

Tabela 5.18: Temperaturas máximas e médias das tintas de cor branca (com adição de cargas

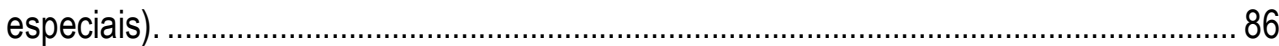

Tabela 5.19: Dados climáticos dos dias 16 e 17 de março de 2007 ........................................... 87

Tabela 5.20: Temperaturas máximas e médias das coberturas com tintas de cor branca. ..... 88

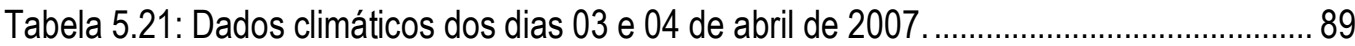

Tabela 5.22: Temperaturas máximas e médias das coberturas com tintas de cor marrom.....90

Tabela 5.23: Dados climáticos dos dias 18 e 20 de maio de 2007 ........................................... 91

Tabela 5.24: Temperaturas máximas e médias das coberturas com tintas de cor amarela....93

Tabela 5.25: Dados climáticos dos dias 11 e 12 de agosto de 2007........................................93

Tabela 5.26: Temperaturas máximas e médias das coberturas com tintas refletivas de cor

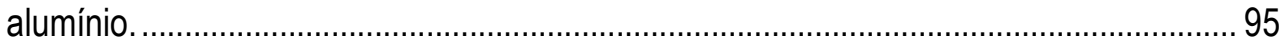

Tabela 5.27: Dados climáticos dos dias 14 e 15 de setembro de 2007....................................95

Tabela 5.28: Temperaturas máximas e médias das coberturas com tintas refletivas de cor

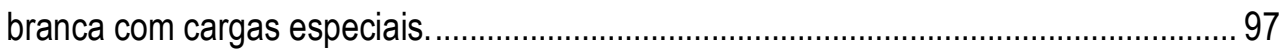

Tabela 5.29: Tabela comparativa entre as tintas refletivas e convencionais do estudo...........99

Tabela 5.30: Valores de refletância total (\%) e da diferença de temperatura média entre a telha de fibrocimento e as telhas pintadas com as tintas do estudo................................... 101 


\section{INTRODUÇÃo}

\subsection{Justificativa}

O crescimento desordenado e exponencial das cidades reflete diretamente no agravamento do aquecimento global. Uma conseqüência desse fenômeno é a elevação da temperatura nas metrópoles, influenciada pelas propriedades radiantes dos materiais empregados na construção do espaço urbano. Estas propriedades estão relacionadas ao microclima da cidade, onde há a formação de áreas urbanas que apresentam alterações climáticas diferenciadas das áreas circunvizinhas. Nas áreas onde ocorre o microclima há o aumento do consumo de energia elétrica devido à necessidade do uso de ar condicionado. Portanto, a eficiência térmica do ambiente construído não é apenas questão de economia de energia, mas também de conforto e preservação do meio ambiente (ARMELIN; CHERRY, 2004).

Como estratégia para contenção dos efeitos do microclima nas cidades, são propostas algumas alternativas: utilizar as sombras das árvores, portanto aumentar as áreas verdes dentro das cidades (criando "oásis"), e aumentar a refletância (coeficiente de reflexão) das superfícies dos materiais utilizados nas edificações. Estas estratégias seriam importantes também para ajudar a cidade a se adaptar às mudanças do clima, e os impactos ambientais causados por este fenômeno (SOLECKI et al., 2005; HIEN; YU, 2003; FERREIRA; PRADO, 2003).

O aumento da temperatura e a necessidade de economia de energia nos últimos anos estimulam

o desenvolvimento de novos produtos visando melhorar o conforto térmico das habitações. 0 desenvolvimento de produtos que se adaptem a essa nova condição, imposta pelo meio ambiente que vivemos é muito importante para diminuir o consumo de energia e os picos de demanda elétrica, devido ao uso de ar condicionado, além de melhorar o conforto térmico dos usuários das edificações. A produção de materiais de construção civil baseados no conceito de 
desenvolvimento sustentável é uma estratégia para a melhoria do conforto térmico da população.

O uso de referências estrangeiras sobre a influência do desempenho térmico de edificações e a sua relação com os materiais construtivos é comum, porém, os dados apresentados nessas publicações muitas vezes não podem ser utilizados para uma avaliação comparativa com os sistemas construtivos brasileiros, devido as nossas características peculiares, como condições climáticas de exposição das construções, tipo de material empregado na construção, os custos, etc. (CASTRO, 2003; ARMELIN; CHERRY, 2004).

A cobertura é a componente da construção mais exposta à radiação térmica. Para a redução de carga térmica e do fluxo de calor emitido pelo telhado, as barreiras radiantes são freqüentemente utilizadas em coberturas (JAHNKE et al., 2006). Segunto Vittorino, Sato e Akutsu (2003), outra forma de reduzir os ganhos de calor pela cobertura é a diminuição da absorção da energia solar pela utilização de materiais de alta refletância na face externa ou redução da quantidade de energia térmica de onda longa irradiada para o interior dos recintos, pelo emprego de materiais com baixa emissividade.

Simpson e McPherson (1997) estudaram os efeitos da modificação da refletância, através da aplicação de tintas em cobertura de residências em Tucson, Arizona, monitorando o uso de energia e as condições ambientais de exposição dos materiais de cobertura. Foram utilizados modelos em escala reduzida, localizados na Universidade do Arizona, no Campus da Faculdade de Agricultura. Os resultados mostraram que as coberturas de cor branca ${ }^{1}$ apresentaram uma temperatura $20^{\circ} \mathrm{C}$ menor do que a cobertura sem pintura e a cobertura de cor alumínio ${ }^{2}$ e uma temperatura de $30^{\circ} \mathrm{C}$ menor do que a cobertura de cor marrom ${ }^{3}$. 0 estudo mostrou que 0 aumento da refletância do material pode reduzir a temperatura e o ganho de calor.

\footnotetext{
${ }^{1}$ Kool-Kote: revestimento para cobertura de cor branca com propriedades elastoméricas.

2 Black Jack: revestimento para cobertura com filamentos de alumínio.

3 Tinta Acrílica-Epóxi Rustic: para acabamento de exterior, cor marrom escuro.
} 
A tinta é um material de construção civil utilizado em várias situações devido as suas propriedades estéticas e protetoras. Aliar estas propriedades ao desempenho térmico de materiais de cobertura utilizados no Brasil, formando um sistema de cobertura telha-tinta seria benéfico, pois melhoraria o conforto térmico dos moradores.

A tinta refletiva apresenta em sua composição um tipo de resina acrílica e pigmentos e/ou cargas que têm a propriedade de refletir mais radiação infravermelha, quando comparada com uma tinta convencional. Desta maneira, devido aos pigmentos refletivos ou cargas presentes, ocorre a reflexão de grande parte dos raios infravermelhos (radiação invisível que contribui para 0 aquecimento dos telhados), diminuindo a temperatura da superfície dos materiais e a transferência de calor entre o meio ambiente e a edificação, o que manteria o ambiente mais agradável.

A modificação das propriedades das tintas, mantendo as suas características estéticas é positiva, quando se compara a tinta refletiva com a tinta convencional. Geralmente as tintas convencionais utilizadas para melhoria do conforto térmico são de cor branca. As tintas refletivas apresentariam a variedade de cores das tintas convencionais com 0 adicional da alta refletância na região do infravermelho.

Estudos da durabilidade dos revestimentos construtivos compostos pelas tintas refletivas ainda não foram realizados no Brasil. O desempenho destas tintas ao longo do tempo é importante para se estudar o efeito das intempéries nas tintas. A deposição de partículas poluentes, a chuva e a exposição à radiação solar prejudicariam o seu desempenho e a sua propriedade de refletir a radiação infravermelha.

$\mathrm{Na}$ tentativa de reduzir a temperatura das coberturas, neste estudo pretende-se avaliar 0 comportamento térmico de tintas refletivas e convencionais de cores correspondentes, visando 
suprir a necessidade de materiais refletivos que apresentem propriedades estéticas coloridas. A escolha da tinta como um dos materiais do sistema construtivo proposto é justificado pela facilidade da sua aplicação em coberturas existentes e da futura incorporação dos pigmentos refletivos nas próprias telhas.

Esta dissertação é motivada pela atual preocupação mundial com relação ao meio ambiente; tendo também como finalidade, discutir novas metodologias a partir do conceito de desenvolvimento sustentável aplicado à área de materiais de construção. Neste contexto há a oportunidade de desenvolver novas tecnologias, novos sistemas construtivos e novos produtos de menor impacto ambiental. A avaliação de revestimentos de pinturas refletivas nacionais e o estudo do seu desempenho térmico quando aplicado a coberturas de habitações brasileiras são importantes devido à falta de conhecimento nesta área de materiais.

\subsection{Objetivo geral}

O objetivo deste estudo é de comparar tintas refletivas com cores correspondentes as tintas convencionais, e verificar se estas tintas têm potencial para melhorar o desempenho térmico das telhas de fibrocimento. A proposta deste trabalho é de estudar a refletância e sua influência no comportamento térmico de tintas refletivas e tintas convencionais aplicadas em telhas de fibrocimento para cobertura de habitações brasileiras.

\subsubsection{Objetivos específicos}

Esta dissertação tem como objetivos específicos:

- Contribuir para o desenvolvimento de uma metodologia para caracterização de uma tinta como refletiva.

- Desenvolver um sistema de cobertura telha-tinta com propriedades refletivas, composto pela telha de fibrocimento e a tinta refletiva. 


\subsection{Estrutura da dissertação}

No Capítulo 1 são apresentadas a justificativa do tema da dissertação, o seu principal objetivo e a estruturação do trabalho.

No Capítulo 2 é apresentada a situação do clima no mundo e os motivos que levaram ao estudo de revestimentos refletivos, mostrando que a preocupação mundial com os problemas relacionados ao meio ambiente, e como estes podem ser amenizados com o desenvolvimento de materiais mais sustentáveis.

No Capítulo 3, são discutidas as diferenças entre as tintas refletivas e as tintas convencionais. São apresentados neste capítulo: a composição básica de ambas as tintas e os diferenciais que as classificam como refletivas.

No Capítulo 4 está apresentado o projeto experimental, os materiais e os métodos utilizados nesta dissertação. A justificativa da escolha dos materiais que compõem os revestimentos refletivos e a descrição dos métodos de ensaio também estão expostas neste capítulo.

No Capítulo 5 são apresentados os resultados e discussões dos ensaios apresentados no Capítulo 4, mostrando se há correlação entre a refletância e o desempenho térmico, além das análises das características de cada tinta estudada.

No Capítulo 6 são apresentadas as conclusões do estudo, mostrando quais as características de uma tinta refletiva, a metodologia para avaliação do seu desempenho térmico e se a tinta pode ser utilizada como um sistema construtivo para redução da temperatura das coberturas visando a sustentabilidade do ambiente construído. 


\section{Revisão da LITERAtura}

\subsection{Radiação Solar}

A radiação solar é um dos fatores fundamentais para a análise do desempenho térmico em edificações, pois dependendo das propriedades das superfícies atingidas pela radiação, ocorrem diferentes processos de transferência de calor entre a habitação e o meio ambiente (CASTRO, 2005).

A troca de energia entre a Terra e o sol ocorre por radiação eletromagnética, portanto o planeta Terra e a atmosfera absorvem radiação solar e a emitem para o espaço. Estas taxas de absorção e emissão são quase equivalentes, de modo que o sistema está muito próximo do equilíbrio radiativo. 0 espectro da radiação eletromagnética engloba a luz visível, os raios gama, as ondas de rádio, as microondas, os raios $\mathrm{x}$, ultravioleta e infravermelho. Estas classificações indicam áreas do espectro divididas com fins didáticos e práticos, pois o espectro é contínuo e não há diferenças abruptas entre as formas de radiação; já que todas são basicamente o mesmo fenômeno físico (LUTGENS; TARBUCK, 1989).

Na Figura 2.1 é apresentado o espectro eletromagnético, onde se observam comprimentos de ondas distintos. Embora o espectro eletromagnético seja contínuo, são atribuídas diferentes classificações para cada intervalo de comprimento de onda devido aos seus efeitos, forma de geração, forma de medida e o uso das suas ondas eletromagnéticas (DUFFIE; BECKMAN, 1991). 


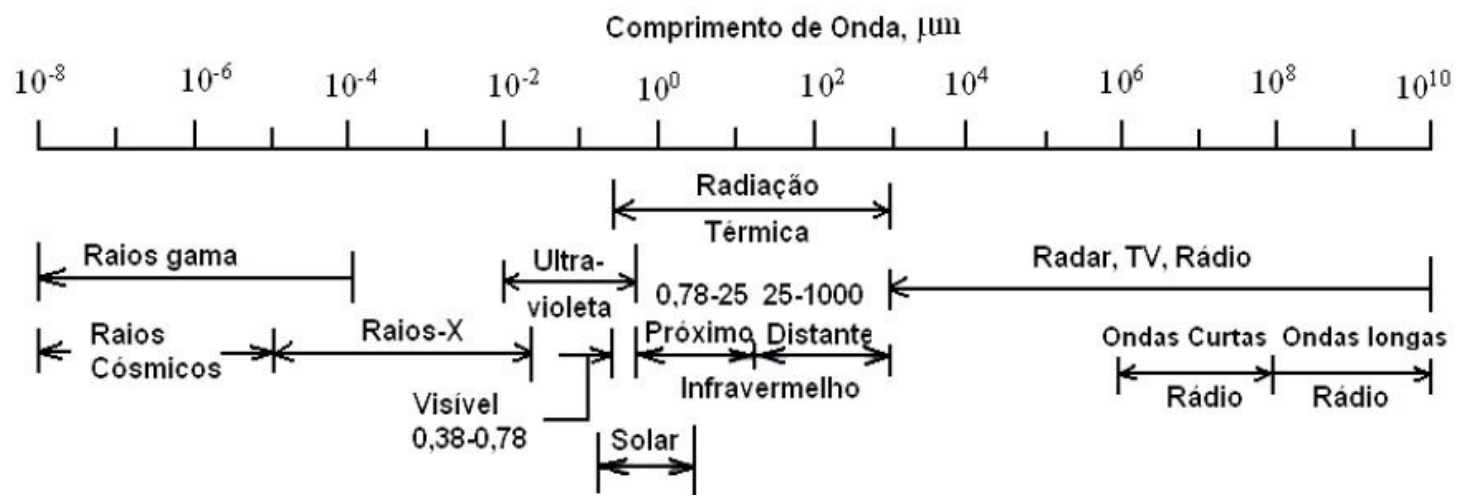

Figura 2.1 Espectro de radiação eletromagnética.

O espectro apresentado na Figura 2.2 se refere à radiação solar, onde são observados os intervalos de onda para cada região do espectro. Estes intervalos, determinados pelos comprimentos de ondas citados apresentam energias distintas e afetam o material de diferentes formas.

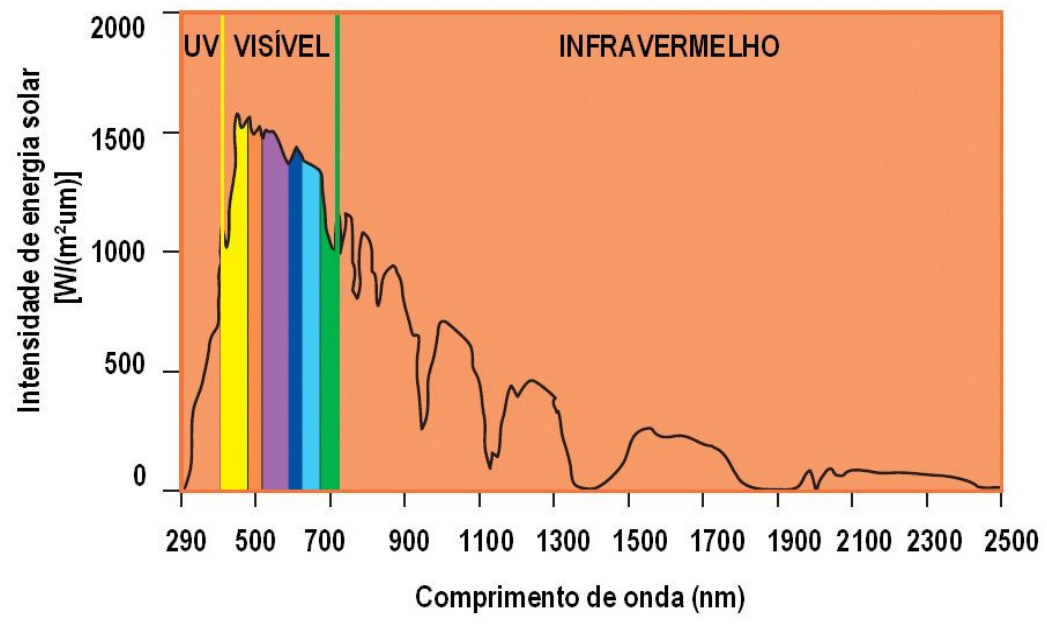

Figura 2.2: Espectro de radiação solar4.

- Região ultravioleta (UV): compreende intervalos de comprimento de onda entre 290 a $380 \mathrm{~nm}$, representa aproximadamente $6 \%$ do espectro solar e é a principal causa da deterioração dos materiais orgânicos devido ao efeito fotoquímico que a radiação UV causa dentro da estrutura do polímero.

- Região do visível (VI): compreende os intervalos de comprimentos de onda entre 381 a

4 Gráfico adaptado do catálogo: The right cool chemistry - Akzo Nobel, 2005. 
$780 \mathrm{~nm}$ e representa cerca de $46 \%$ de todo o espectro solar, determinando as cores dos objetos. Verifica-se que os diferentes comprimentos de onda (as diferentes cores) produzem diversas sensações de luminosidade; isto é, o olho humano não é igualmente sensível a todas as cores do espectro visível (RODRIGUES, 2002).

- Região do infravermelho (IV): corresponde aproximadamente a $43 \%$ do espectro solar e o seu intervalo de comprimento de onda está contido entre $781 \mathrm{~nm}$ até aproximadamente 2500nm (FERREIRA; PRADO, 2003). É a região responsável pelas trocas de energia térmica entre os corpos. A radiação infravermelha é invisível ao olho humano, sendo uma "fonte de calor" que interfere nas condições internas do ambiente, através do ganho de calor (CASTRO, 2002).

Este espectro é apenas uma extensão da luz visível, pois o olho humano só é sensível a uma estreita faixa de radiações situadas entre o vermelho e o violeta (400 a 700nm). Uma diferença de apenas centésimos de milésimos de centímetros de comprimento de onda estabelece a diferença entre a visibilidade e a invisibilidade. O sol emite outras espécies de radiações, que podem ser sensíveis ou não, ao olho humano. O infravermelho, por exemplo, não pode excitar a retina para dar a sensação de luz, embora a pele a sinta em forma de calor (OUCHI, 2005).

Segundo Ceballos (2000), da energia total que incide na atmosfera terrestre apenas parte chega até a superfície terrestre, conforme apresentando na Figura 2.3, a Terra recebe energia através da radiação solar e perde energia através da radiação infravermelha térmica para o espaço, sendo esta troca de energia que determina a temperatura da Terra. 


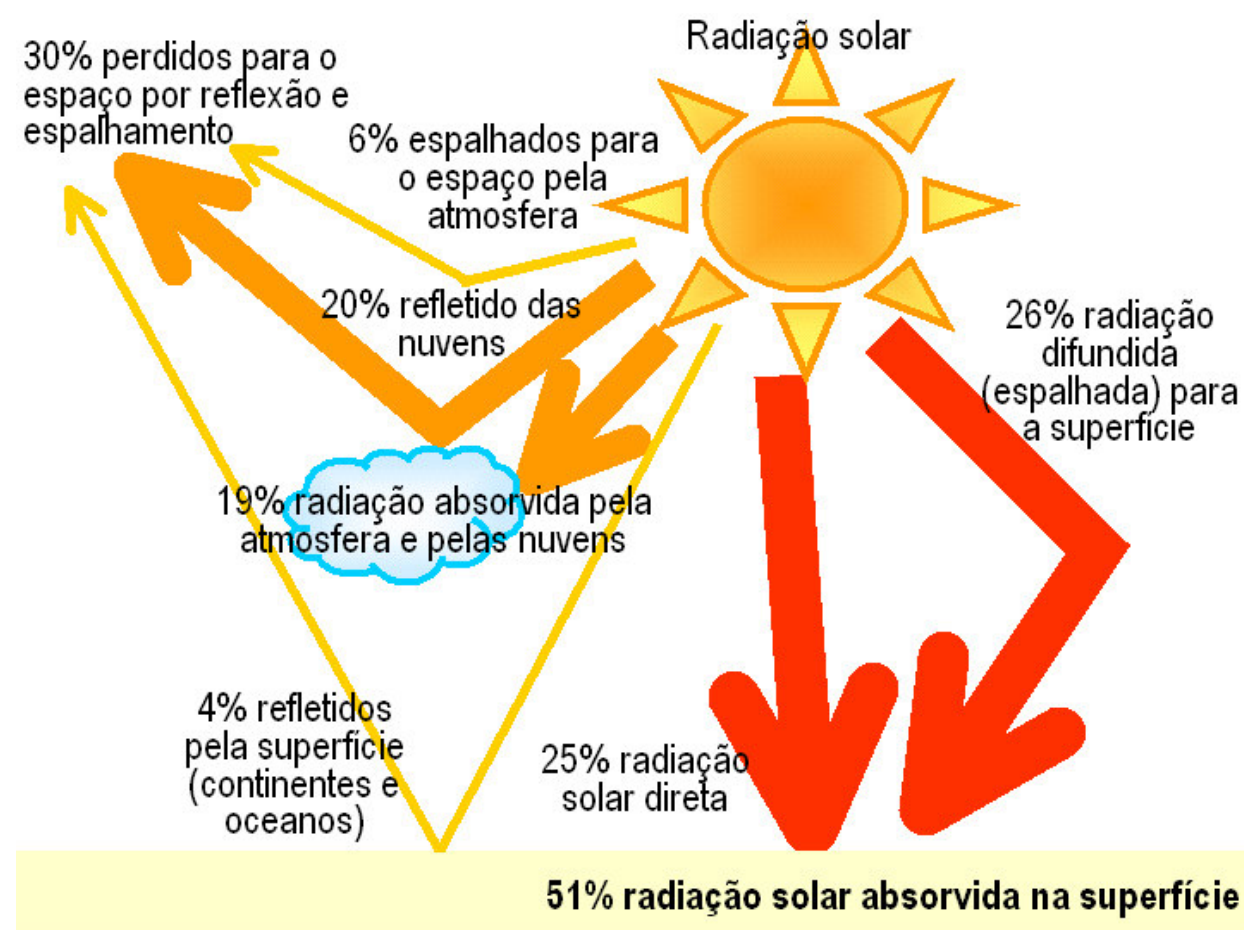

Figura 2.3: Distribuição percentual da radiação solar incidente 5 .

Aproximadamente $30 \%$ da energia solar é refletida e/ou retroespalhada de volta para o espaço, esta reflexão ocorre na interface entre dois meios diferentes. Deste total da radiação solar, $51 \%$ é absorvida pelas superfícies dos materiais expostos. Embora a atmosfera seja muito transparente à radiação solar incidente, somente $25 \%$ da radiação solar passa diretamente para a superfície da Terra sem nenhuma interferência da atmosfera. O restante é refletido, absorvido ou espalhado de volta para o espaço até atingir a superfície da Terra ou retornar ao espaço.

Segundo Martinazzo (2004), na atmosfera terrestre existe uma grande quantidade de nitrogênio e o oxigênio, assim como as moléculas de água e aerossóis. A radiação solar incide em linha reta e os elementos que espalham a radiação solar podem dispersá-la em todas as direções.

A radiação direta é a radiação solar recebida "diretamente" do sol pelos componentes construtivos, com exceção da radiação que é espalhada, absorvida ou refletida por componentes atmosféricos. A parcela da radiação solar que é espalhada pelos componentes atmosféricos,

${ }^{5}$ Esquema adaptado do site: http://fisica.ufpr.br/grimm acesso em fevereiro de 2006 
citados anteriormente, é denominada radiação difusa (MARTINAZZO, 2004). Na Figura 2.4 é apresentada a distribuição da radiação solar em uma edificação e como ela afeta diretamente os componentes construtivos.

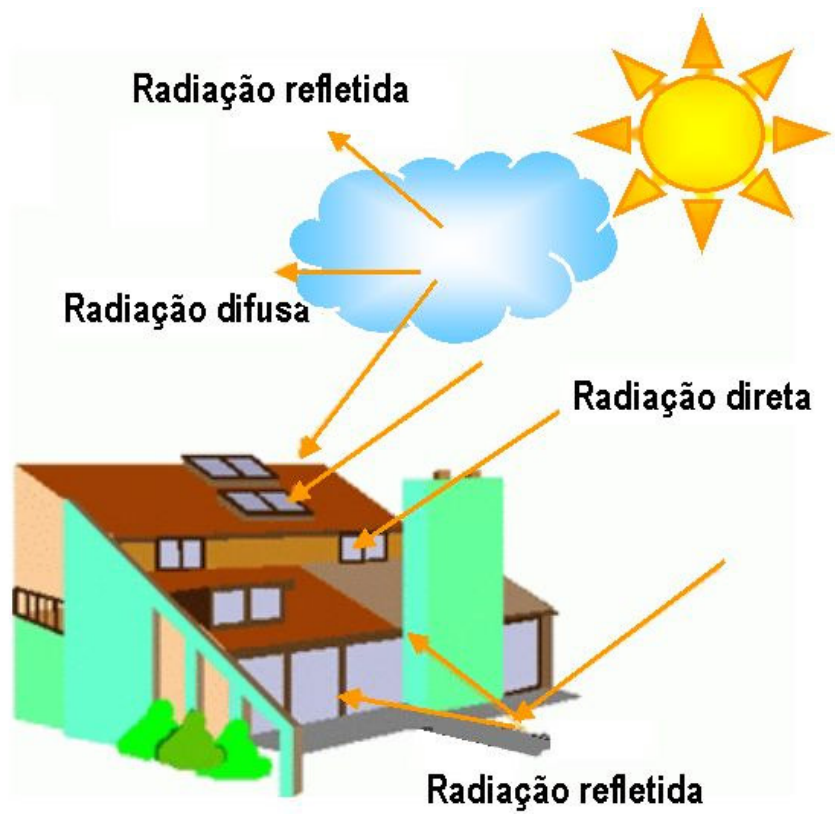

Figura 2.4: Esquema distribuição da radiação solar em uma edificação6.

Uma modelagem da propagação da radiação solar na atmosfera não é simples de ser efetuada; devido à complexidade das interações combinadas com componentes atmosféricos, tais como fases, nuvens e aerossol (citadas anteriormente) e a variabilidade espaço-temporal que existe entre eles (CEBALLOS, 2000).

\subsubsection{A influência da radiação solar no conforto térmico dos usuários}

O clima ao redor das construções é determinado por vários fatores climáticos como a radiação solar, temperatura do ar, umidade relativa e a velocidade dos ventos. Esses parâmetros influenciam diretamente na transferência de calor que ocorre entre a habitação e o meio ambiente através das paredes, telhados, portas e janelas. Internamente o ganho de calor reflete nos usuários, podendo causar um desconforto térmico no verão e levando ao um consumo maior

${ }^{6}$ Adaptado de www.raplus.pt/termico.htm, acessado em julho de 2006. 
de energia, devido ao uso constante de ar condicionado (SIMPSON; MCPHERSON, 1997).

As diferenças do microclima urbano têm sido cada vez mais perceptíveis em grandes cidades, como São Paulo. Observa-se que em São Paulo existem cânions urbanos, onde a sombra de edifícios, construídos próximos uns dos outros, cria zonas frias no meio das ilhas de calor, e existem regiões muito quentes devido a concentração cada vez maior de construções e diminuição de áreas verdes (SOARES, 2007).

Segundo estudos do Instituto de Estudos Avançados da Universidade de São Paulo (IEA-USP), em São Paulo as temperaturas entre microclimas ${ }^{7}$ podem variar até $10^{\circ} \mathrm{C}$. Essa diferença de temperatura ocorre em pontos da cidade que não ultrapassam 10 quilômetros de distância. Na Figura 2.5 é apresentado o perfil da curva de temperatura de uma cidade onde ocorre 0 fenômeno do microclima, observa-se uma elevação da temperatura no centro da cidade. $\mathrm{Na}$ Figura 2.6 é apresentado um mapa da cidade de São Paulo com medição de temperaturas máximas feitas por imagens térmicas de satélite no último verão segundo Soares (2007).

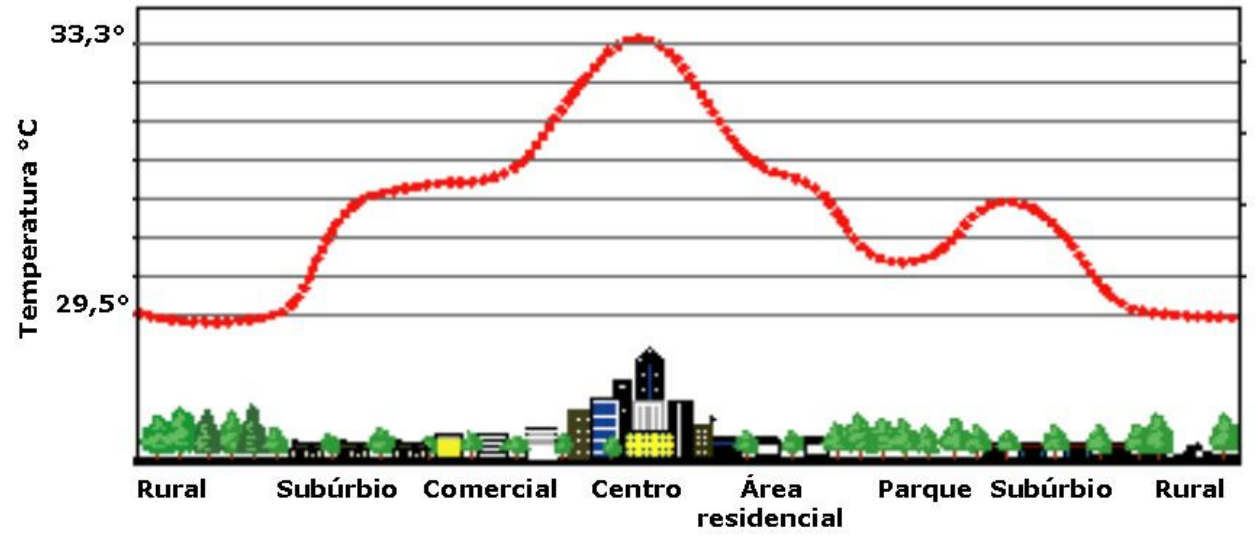

Figura 2.5: Perfil de uma cidade com microclima ${ }^{8}$.

\footnotetext{
70 microclima ocorre em determinadas regiões que apresentam um clima diferente das regiões do seu entorno, sendo relativamente comum em grandes áreas urbanizadas. 0 microclima existe, por exemplo, em metrópoles onde as construções e 0 asfalto absorvem a energia solar, e concentram 0 calor nessas regiões, 0 que resulta nas chamadas ilhas de calor.

${ }^{8}$ Adaptado do site http://www.ghcc.msfc.nasa.gov/urban/urban_heat_island.html, acesso em 20/03/06.
} 


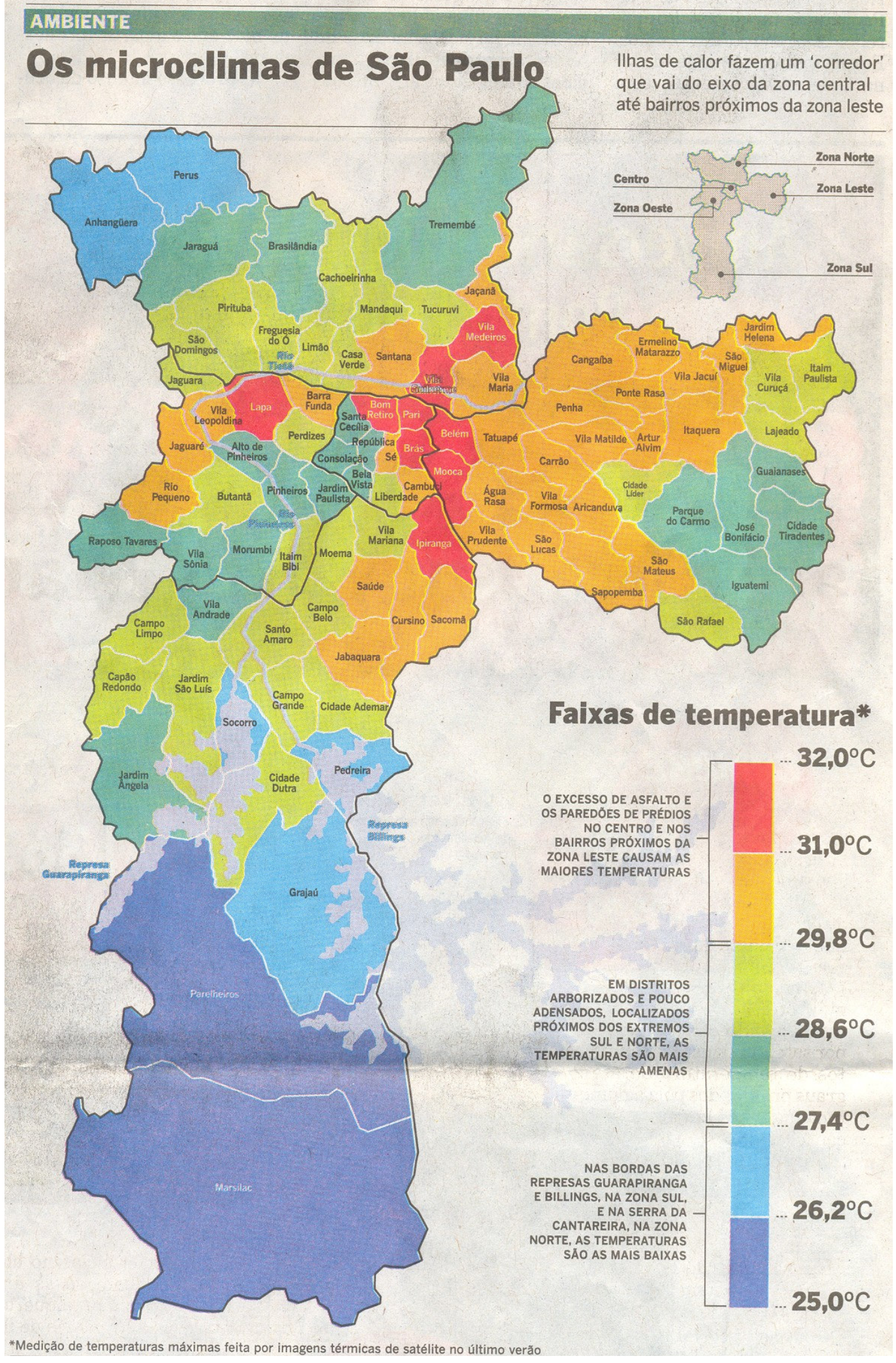

Figura 2.6: Microclimas da cidade de São Paulo. 
Nos verões de Atenas na Grécia, o fenômeno das ilhas de calor altera radicalmente a temperatura das áreas urbanas modificando o seu microclima. A média de temperatura chega a ser $5,6^{\circ} \mathrm{C}$ maior que nos arredores da cidade, que são de zonas rurais (SYNNEFA; SANTAMOURIS; LIVADA, 2005). De acordo com medidas realizadas por Santamouris et al (1999, 2001), Mihakajakou et al (2002) e Livada et al (2002) em 30 estações urbanas e de periferias nos verões de 1997 , o fenômeno das ilhas de calor se intensificou chegando a $10^{\circ} \mathrm{C}$. Isto acarretou em um aumento no uso de ar condicionado em prédios comerciais e dobrou os valores em picos de eletricidade. No inverno o calor concentrado nas zonas de intensa urbanização é reduzido em cerca de 30\% (KOLOKOTRONI, 2006).

Na cidade de São Paulo que se encontra em situação de estabilidade atmosférica com ausência de ventos, e inversão térmica freqüentes no inverno, o fenômeno chamado ilha de calor aparece na sua plenitude (PAULA, 2005). Na Figura 2.7 é apresentado um mapa produzido por foto via satélite da cidade de São Paulo. A cor vermelha indica as áreas com temperaturas elevadas e a azul, com temperaturas mais baixas. As zonas em amarelo e verde apresentam áreas com temperaturas mais amenas. Nos pontos brancos, observa-se uma região densamente edificada e povoada, é nestas áreas que há a maior ocorrência das ilhas de calor. Os limites dessas ilhas de calor ocorrem em direção a Zona Oeste, até serem barradas pela brisa marítima do litoral paulista; já ao norte, são limitadas pela Serra da Cantareira. Os chamados "oásis" ocorrem na metrópole, onde as temperaturas são mais amenas devido à ocupação residencial horizontal e com predominância de arborização entre as edificações (CHAGAS, 2005). 


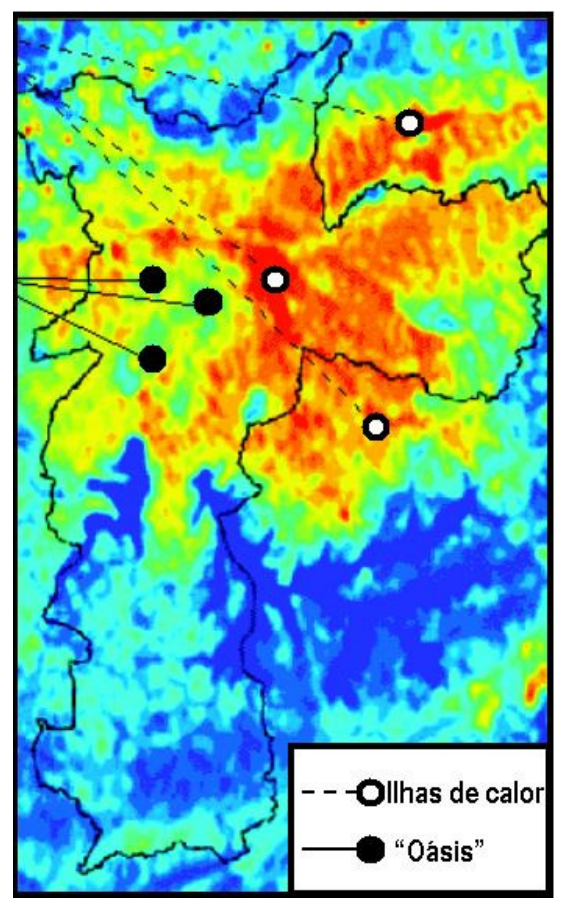

Figura 2.7: Mapa da cidade de São Paulo, caracterizando regiões onde ocorrem as ilhas de calor.

O aumento da temperatura no entorno das metrópoles é um fato apresentado em várias localidades do. Na Tabela 2.1 é apresentada uma síntese das diferenças de temperatura das ilhas de calor, estudadas em diversas localidades, por autores distintos.

Tabela 2.1:Exemplos de diferença das temperaturas devido ao efeito das ilhas de calor.

\begin{tabular}{|c|c|c|c|}
\hline Localização & $\begin{array}{c}\text { Diferença de } \\
\text { temperatura }\left({ }^{\circ} \mathrm{C}\right)\end{array}$ & Autores & $\begin{array}{c}\text { Ano da } \\
\text { publicação }\end{array}$ \\
\hline Hong Kong & 1,5 & Gitidharan, Lau, Ganesan & 2005 \\
\hline Porto Rico & 2,5 & Velazquez-Lozada, Gonzalez, Winter & 2006 \\
\hline Londres (Inglaterra) & 2,6 & Kolokotroni, Giannitsaris, Watkins & 2006 \\
\hline Rio de Janeiro (Brasil) & 4 & Paiva & 2003 \\
\hline Cingapura & 4 & Hien, Yu & 2003 \\
\hline Nova Jersey (EUA) & 4,5 & Rosenzweig, et al & 2005 \\
\hline Atenas (Grécia) & 5,6 & Synnefa, Santamouris, Livada & 2005 \\
\hline Bancoc (Tailândia) & 6 & Hung et al & 2006 \\
\hline Tóquio (Japão) & 8,0 & Zorzetto & 2004 \\
\hline São Paulo (Brasil) & 10 & &
\end{tabular}

\subsubsection{Estudos para melhoria do conforto térmico}

Nos Estados Unidos, uma das alternativas para aumentar o conforto térmico e a redução do consumo de energia devido ao uso de ar condicionado é a utilização de produtos (telhas, tintas, 
barreiras radiantes) de elevada refletância em coberturas. Para se utilizar este tipo de material nas coberturas brasileiras há necessidade de aumentar o conhecimento sobre estes produtos, antes da sua aplicação e/ou utilização final.

O conceito de "comunidades frias" foi implementado nos EUA, através da inclusão de uma normalização para códigos de edificações, onde os materiais utilizados nas coberturas e nas paredes das construções, não atinjam temperaturas elevadas quando expostas à radiação solar. O propósito destas normas é promover a utilização de materiais com refletância elevada, e que se mantenham "frios" quando expostos à radiação solar (FERREIRA, 2003).

Esta preocupação mundial com o aquecimento global é mostrada na implementação de medidas para a mitigação dos efeitos das ilhas de calor. Parte do manifesto "Climate Change Action Plan"9 do ex-presidente dos EUA, Bill Clinton, apresenta como plano de ação o controle da emissão de "greenhouse gases", para a diminuição do aquecimento global e suas conseqüências, além da redução de custos no setor elétrico (ROSENFELD et al., 1995).

\subsection{Refletância}

A intensidade da radiação solar emitida pelo sol varia de acordo com o intervalo de comprimento de onda onde ela está situada. A refletância é uma propriedade física fundamental para se entender o comportamento térmico dos materiais.

Conforme definido na NBR15220-1 de desempenho térmico de edificações, refletância é o quociente da taxa de radiação solar refletida por uma superfície, pela taxa de radiação solar incidente sobre esta mesma superfície.

${ }^{9}$ CLIMATE CHANGE ACTION PLAN. The Committee on the Environment and the Northeast International Committee on Energy of the Conference of New England Governors and Eastern Canadian Premiers (Agosto, 2001). 


\subsubsection{Comportamento refletivo dos materiais}

O comportamento refletivo de um material depende da refletância especular e da refletância difusa. A refletância especular ocorre quando a superfície da amostra consegue refletir toda a luz incidente num mesmo ângulo como se fosse um "espelho". Já a refletância difusa ocorre quando a superfície da amostra reflete a luz incidente em diversos ângulos dispersos devido à irregularidade da superfície, estes fenômenos são ilustrados na Figura 2.8.

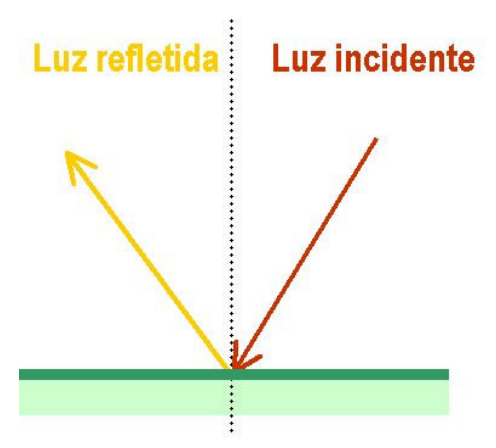

Refletância especular

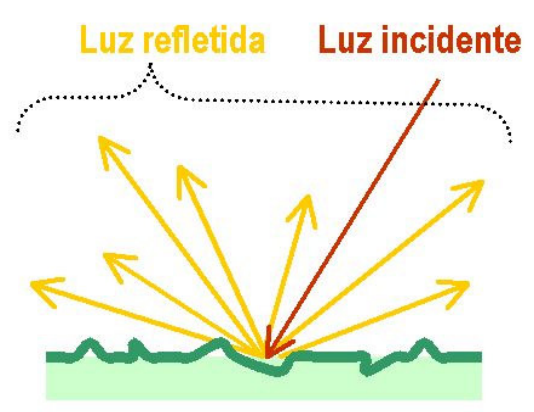

Refletância difusa

Figura 2.8: Esquemas de refletância especular e difusa ${ }^{10}$.

Na Tabela 2.2 são apresentados valores típicos de refletância segundo Studervant (2000), Thevenard e Haddad (2006), quanto mais clara é a superfície do material, maior é o seu valor de refletância. Na composição da tabela foram consideradas médias de valores medidos ao longo de um dia. Observa-se que revestimentos brancos refletivos refletem $85 \%$ da radiação solar e absorvem aproximadamente $15 \%$. Esta propriedade física aliada a outras, pode ajudar a não aumentar a temperatura do material e contribuir para uma melhora do conforto térmico.

Tabela 2.2: Valores típicos de refletância.

\begin{tabular}{|c|c|}
\hline Material & Refletância (\%) \\
\hline Revestimento refletivo branco & 85 \\
\hline Tinta branca & 60 \\
\hline Areia do deserto & 40 \\
\hline Concreto & 22 \\
\hline Betumem (asfalto) & 9 \\
\hline Água (largos ângulos de incidência) & 7 \\
\hline
\end{tabular}

\footnotetext{
${ }^{10}$ Adaptado de http://www.shimadzu.com.br, acesso em julho de 2006.
} 
Superfícies com valores altos de refletância apresentam alta refletividade na luz visível (381 a 780nm) e, portanto teoricamente, apresentam cores mais claras (THEVENARD; HADDAD, 2006; SAILOR; RESH; SEGURA, 2006). Esta característica será discutida neste trabalho, com a determinação dos valores de refletância por espectrofotometria aliada à avaliação térmica de tintas coloridas com propriedades refletivas.

\subsubsection{Fatores que interferem na refletância dos materiais}

A variação dos valores de refletância ocorre devido a uma infinidade de fatores, como a superfície dos materiais (rugosidade), clima do ambiente onde o material está sendo exposto (como radiação solar, temperatura e presença de nuvens), etc (SIMPSON, McPHERSON; 1997).

\subsubsection{Rugosidade}

Cada material absorve energia radiante em determinada freqüência de ressonância. As freqüências mais altas do espectro solar, nas regiões do ultravioleta e do visível, são absorvidas em função da densidade das ligações atômicas da substância, enquanto as mais baixas, no infravermelho, uma escala molecular (RORIZ; DORNELLES; RORIZ, 2007).

Segundo Bretz e Akbari (1997) substratos rugosos podem apresentar uma refletância superficial menor quando comparado a um substrato liso devido a efeitos geométricos e às partículas suspensas de ar que se acumulam nas irregularidades das superfícies.

A rugosidade de uma superfície é definida por suas micro-irregularidades geométricas. Os materiais de construção civil, geralmente apresentam certa irregularidade nas suas superfícies, onde há picos e vales de diferentes alturas e a diferentes distâncias (RORIZ; DORNELLES; RORIZ, 2007).

\subsubsection{Exposição às variáveis ambientais}

Segundo Bretz, Akbari e Rosenfeld (1997) não se deve considerar somente o valor inicial da 
refletância; a monitorização do seu desempenho durante a exposição deve ser realizada. Superfícies com cores escuras (baixa refletância na região do visível) tendem a aumentar a refletância com o passar do tempo devido à concentração de sujeiras e de poluição, além da oxidação dos materiais. Em contraste, coberturas com alto valor de refletância, geralmente de cores brancas, tendem a diminuir o valor da refletância.

A refletância de uma cobertura pode ser alterada com o passar do tempo, devido a sua exposição às intempéries, por isso devem ser realizadas limpezas periódicas para amenizar este problema. Estudos realizados por Levinson et al (2005) de exposição ao ambiente natural com 10 tipos de telhados na Califórnia mostraram que a refletância destes "materiais frios" pode diminuir cerca de $15 \%$ no primeiro ano de exposição.

Na Figura 2.9, observam-se os valores de refletância com e sem manutenção periódica. Um fator importante para a avaliação da durabilidade deste tipo de material é a resistência à sujidade e a pegajosidade da película de tinta.

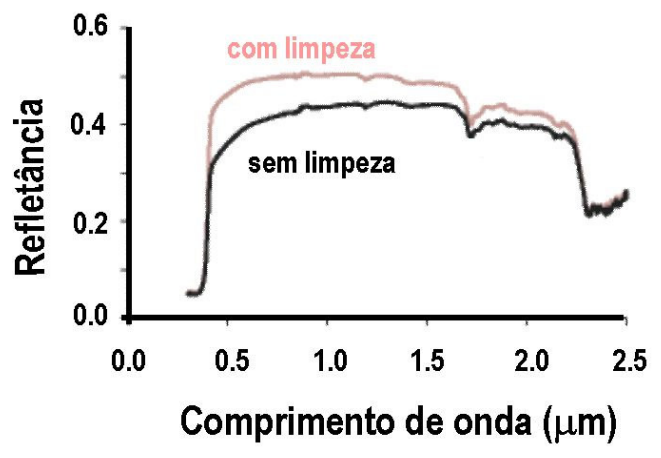

Figura 2.9: Benefícios de uma manutenção regular das tintas refletivas aplicadas à materiais de cobertura ${ }^{11}$

O envelhecimento da superfície é causado pela contaminação por poluentes atmosféricos, agentes biológicos, e outras alterações resultado da ação da radiação UV. Para um estudo da durabilidade de uma pintura, deve-se observar que as amostras são afetadas pelo clima onde a

${ }^{11}$ Adaptado de http://eetd.Ibl.gov/Heatlsland, acessado em julho de 2006. 
amostra está exposta (SYNNEFA; SANTAMOURIS; LIVADA, 2005).

Synnefa, Santamouris e Apostolakis (2006) realizaram um estudo com tintas coloridas refletivas na Grécia, onde foram avaliados comparativamente o desempenho térmico de tintas coloridas refletivas e convencionais durante o período de 3 meses, com constante monitoração de temperatura. Os resultados mostraram que é possivel a utilização de tintas coloridas com propriedades refletivas e significativa eficiência térmica, mas que uma manutenção periódica é necessária para que estas propriedades refletivas sejam mantidas.

Portanto, uma tinta refletiva deve apresentar elevada durabilidade, e não permitir a deposição de partículas do meio (fator sujidade) que poderia comprometer as suas propriedades refletivas. Para que não seja necessária uma manutenção freqüente estão sendo estudadas adições especiais na formulação das tintas, dificultando a deposição de partículas sobre as películas ou que favoreçam a remoção da camada superficial sem prejudicar o aspecto estético (TATUM, 1999).

\subsubsection{Correlação da refletância com o desempenho térmico}

Para o estudo das propriedades térmicas de um material, a refletância à região do infravermelho está diretamente relacionada ao desempenho térmico dos materiais, já que é esta região do espectro solar que contribui para o aumento da temperatura dos materiais.

Segundo estudos de Bretz, Akbari e Rosenfeld (1997) existem várias modificações que podem ser realizadas nas edificações para a melhoria do seu desempenho térmico. Telhados e paredes podem ser repintados com cores claras; e os materiais de cobertura dos telhados podem ser substituídos por telhas de metal, de concreto ou de cerâmica na cor branca; com estas simples mudanças de materiais nas construções há o aumento da refletância. Por exemplo, uma superfície cinza ou preta, possui refletância próxima de 10\%, já uma superfície branca apresenta 
a refletância em torno de 50-70\%. A vegetação ao redor da edificação apresenta uma refletância de 25-30\%. O aumento da refletância em coberturas pode auxiliar a diminuição do aquecimento do ar e a diminuir o efeito do calor nos usuários (LUXMOORE; JAYASINGHE; MAHENDRAN, 2005).

A modificação do ganho de calor pela absorção da radiação solar é viável segundo estudos de Collados e Sánchez (2003), que concluíram que o aumento de refletância da superfície dos materiais, a irrigação da superfície expostas ao calor e o aumento da vegetação em áreas totalmente edificadas, podem ser meios efetivos para a mitigação ou reversão da corrente de calor gerada pelo microclima nas cidades.

Coberturas de edificações com alta refletância à radiação solar tendem a se manterem "frias" quando expostas à radiação solar. Este tipo de cobertura transfere menos calor para o interior da edificação do que uma cobertura tradicional; como resultado observa-se uma melhoria do conforto térmico no interior da edificação. Além disso, devido à diminuição da dilatação térmica, há o aumento da vida útil das telhas da cobertura e conseqüentemente, a redução do resíduo deste material (LEVINSON et al., 2005; LEVINSON; AKBARI; REILLY, 2007).

Pesquisas realizadas em Sacramento, Califórnia (EUA), mostraram que os materiais de construção civil apresentam diferentes valores de refletância, que podem ser potencializados com aumento das áreas verdes e com a modificação das cores dos materiais de construção das edificações. Para estimular a consciência ambiental da população, a prefeitura de Sacramento aumentou em $80 \%$ a área verde da cidade concedendo descontos no imposto territorial através de incentivo fiscal (SOARES, 2007).

Os dados da Tabela 2.3 mostram a distribuição por área da cidade de Sacramento. As áreas residenciais apresentam $28 \%$ de coberturas para telhados, $16 \%$ de ruas, $14 \%$ de outras 
superfícies como parques, rodovias e calçadas. Baseado nestes valores pode-se estimar 0 potencial de modificação da refletância urbana em 18\% para a cidade de Sacramento (BRETZ; AKBARI; ROSENFELD, 1997).

Tabela 2.3: Composição da superfície estimada de Sacramento - Califórnia

\begin{tabular}{|c|c|c|c|c|}
\hline Tipo de superfície & $\begin{array}{c}\text { Área }(\% \\
\text { da } \\
\text { cidade) }\end{array}$ & $\begin{array}{c}\text { Refletância } \\
\text { teórica }(\%)\end{array}$ & $\begin{array}{c}\text { Refletância } \\
\text { medida }(\Delta \%)\end{array}$ & $\begin{array}{c}\text { Potencial de } \\
\text { modificação da } \\
\text { refletância }(\Delta \%)\end{array}$ \\
\hline Coberturas de cores escuras & 20 & $5-10$ & 50 & 10 \\
Cobertura de cores claras & 8 & $50-80$ & 0 & 0 \\
\hline Ruas & 16 & $5-40$ & 30 & 5 \\
\hline Parques, rodovias, calçadas & 10 & $5-15$ & 30 & 3 \\
Cores escuras & 4 & $35-40$ & 0 & 0 \\
Cores claras & 58 & - & - & 18 \\
\hline Total & &
\end{tabular}

\subsection{Comportamento térmico de materiais de cobertura}

O comportamento térmico das edificações depende de vários fatores como orientação das janelas, isolamento térmico, variação da temperatura do ar, umidade relativa do ar, direção e a velocidade do vento e a radiação solar, cor da superfície externa (SIQUEIRA et al., 2005). Parte do aumento do calor no interior das edificações é resultado do uso de coberturas constituídas de materiais tradicionais que possuem cores escuras, tornando-as receptíveis à radiação solar e elevando a temperatura do interior das edificações.

Em uma construção térrea é a cobertura que está mais exposta à radiação solar e tem um papel importante dentro da avaliação do desempenho térmico de uma edificação. O efeito conjugado entre a radiação solar e a temperatura do ar, pode elevar a temperatura da superfície da cobertura em até $80^{\circ} \mathrm{C}$. Segundo Basso, Lucini e Roriz (1991) o conceito de desempenho térmico para coberturas envolve três aspectos: capacidade de proporcionar conforto térmico aos habitantes no interior da edificação, diminuição do consumo de energia e evitando-se patologias, resultantes da movimentação excessiva devido a processos de dilatação e contração.

O Brasil possui certas regiões com um clima úmido onde é freqüente à condensação da umidade 
do ar na cobertura. Se esta água for totalmente absorvida pela cobertura, uma parte da radiação solar incidente será consumida na evaporação desta água no dia seguinte (CAVALCANTI, 2001).

Dos tipos de materiais de cobertura comumente utilizados, é a telha cerâmica que apresenta o melhor desempenho térmico; um dos fatores é a sua alta absorção de água. Durante a noite ocorre à queda da temperatura, e perdas de calor, portanto, a superfície do telhado permanece com uma temperatura mais baixa que a do ambiente externo, desta maneira parte da radiação incidente durante o dia é consumida no processo de evaporação da água que é absorvida, somente depois de terminado este processo é que as telhas começam a se aquecer. Outra razão para que as telhas cerâmicas apresentem melhor desempenho térmico refere-se à infiltração do ar pelos espaços entre as telhas (MICHELS, 2007).

Há uma grande variedade de materiais de cobertura utilizados no Brasil. As telhas de fibrocimento geralmente são utilizadas em edificações para população de baixa renda, por possuir um custo inferior em relação às telhas de barro. Segundo Cavalcanti (2001), a capacidade de absorção de água das telhas de fibrocimento é bem menor que a das telhas de cerâmica, influenciando no seu desempenho térmico. Assim, procuram-se alternativas para a melhoria do desempenho térmico daquele tipo de telhado, objetivando melhorar o conforto térmico do ambiente interno para os usuários.

\subsubsection{Influência das cores dos materiais de cobertura no desempenho térmico}

Quando as superfícies externas das coberturas são expostas diretamente à radiação solar há um ganho de calor no ambiente interno das construções. O efeito da cor na temperatura do ar interno do ambiente depende de vários parâmetros, além da refletância, como a resistência térmica e a capacidade térmica. Quando a espessura do material que compõe o sistema 
construtivo é considerável, a inércia térmica passa a prevalecer sobre a influência da cor (CASTRO, 2005).

Superfícies brancas apresentam uma alta refletância no espectro visível, como pode ser observado na Figura 2.10. Teoricamente as superfícies escuras são quentes devido a sua baixa refletância no espectro visível e no infravermelho (LEVINSON et al., 2005).
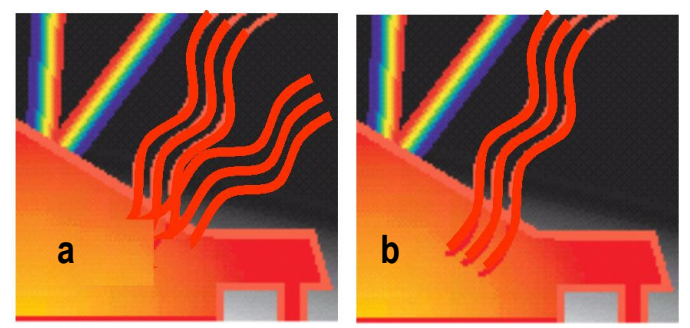

Figura 2.10: llustração da radiação solar em uma cobertura com alta refletividade (a) e com baixa refletividade $(b)$ à radiação solar ${ }^{12}$.

Estudos de Simioni e Clezar (2003) para determinar o desempenho térmico de coberturas, concluíram que a opção por cores claras de telhas auxilia a minimizar o problema e apresenta baixo custo, sendo que a única preocupação seria com a manutenção das telhas para que as mesmas não acumulem sujeira, o que prejudicaria a sua propriedade refletiva.

A preocupação estética também incentivou a produção de tintas coloridas refletivas. A maioria dos materiais refletivos encontrados no mercado é predominantemente de cor branca. A presença de pigmentos especiais influenciaria nas propriedades térmicas deste tipo de tinta (SYNNEFA; SANTAMOURIS; APOSTOLAKIS, 2006).

Conforme discutida anteriormente a influência da cor dos materiais de cobertura e a sua correlação com o conforto térmico dos usuários no ambiente interno das edificações, é um fator importante na produção de tintas refletivas.

No mercado exterior estão sendo comercializadas tintas compostas por pigmentos coloridos,

12 llustração adaptada do catálogo: The right cool chemistry - Akzo Nobel, 2005. 
com propriedades refletivas. Resultados obtidos por Ikematsu, Uemoto e Sato (2006) mostraram que uma tinta de cor verde apresentou valores de refletância à radiação infravermelha superiores a uma tinta acrílica branca para fachadas.

\subsubsection{Transferência de calor}

Quando existe uma diferença de temperatura entre duas regiões do espaço, esta tende a desaparecer devido a passagem de calor de uma região para outra. Este conjunto de fenômenos caracterizados pela passagem de calor é chamado de transferência de calor (COSTA, 1991). 0 calor é a energia transferida entre dois sistemas que se encontre em temperaturas distintas até atingirem o equilibrio térmico. A energia que um corpo recebe na forma de calor pode ser transformada em energia interna, o que acarreta em um aumento de temperatura.

A transferência de calor ocorre por três processos: condução, convecção e radiação, como podem ser observados na Figura 2.11. Na condução, a energia térmica é transferida pelas interações dos átomos ou de moléculas vizinhas, sem haver deslocamento dos mesmos, na convecção, o calor é transferido pelo transporte direto de massa, e na radiação, a energia é transferida através do espaço, por meio de ondas eletromagnéticas (CAVALCANTI, 2001).

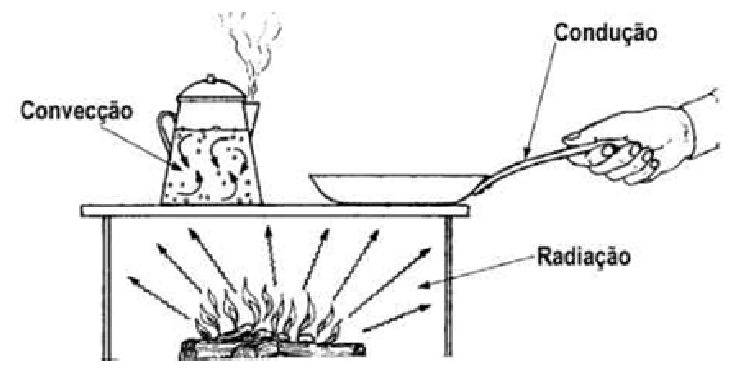

Figura 2.11: Esquemas simplificados de mecanismos de transferência de calor.

Os mecanismos de transferência de calor podem ocorrer pelos seguintes mecanismos (ARMELIN; CHERRY, 2004; COSTA, 1991):

- Condução é a transferência de energia realizada de partícula para partícula, sem que 
haja transporte de matéria de uma região para outra. Na condução, a energia cinética dos átomos e moléculas é transferida por colisões entre átomos e moléculas próximas a elas; onde o calor flui das moléculas com maior energia cinética para as moléculas com menor energia cinética, conforme apresentado na Figura 2.12.

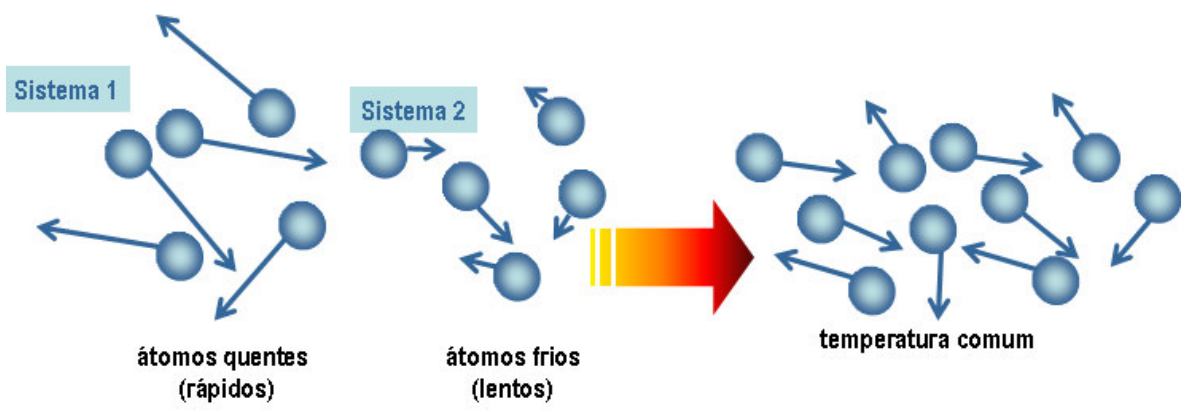

Figura 2.12: Esquema do mecanismo de condução.

- Convecção é a transferência de calor que o ocorre de molécula a molécula, onde simultaneamente, verifica-se o transporte de matéria de região para região (vide Figura 2.13). É um mecanismo de transferência de energia que ocorre quando o ar em movimento entra em contato com a superfície, valendo a condição das mesmas se encontrarem em temperaturas distintas.

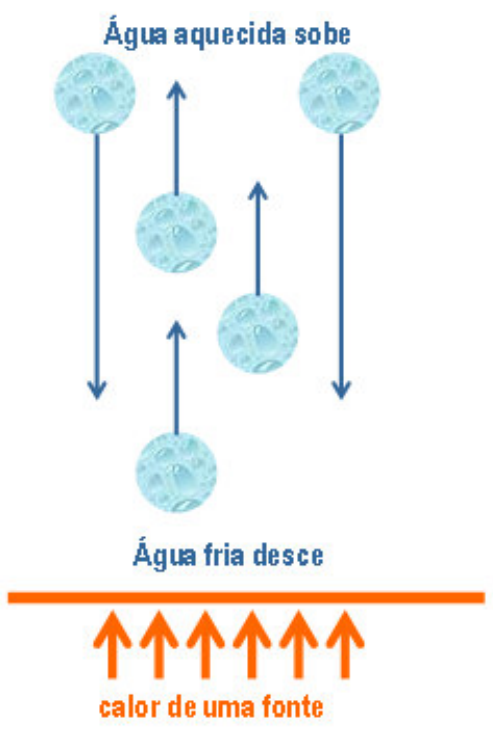

Figura 2.13: Esquema do mecanismo de convecção. 
- Irradiação ou radiação térmica é a energia radiante transportada de um corpo através de ondas eletromagnéticas, que se propagam em diversos meios, mesmo no vácuo. Tratase da energia calorífica emitida sob a forma de radiações semelhantes à luz; conforme apresentado na Figura 2.14).

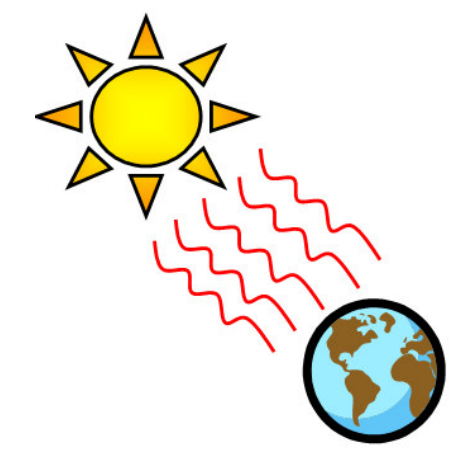

Figura 2.14: Esquema do mecanismo de irradiação.

\subsubsection{Transferência de calor em coberturas}

Medições de desempenho térmico de coberturas de telhas de cerâmica, concreto e fibrocimento mostraram que a superfície da telha de cobertura atinge temperaturas superiores a $60^{\circ} \mathrm{C}$. Esta condição faz com que o calor passe a entrar na edificação através dos três mecanismos principais apresentados anteriormente: radiação térmica, convecção e condução (ARMELIN; CHERRY, 2004).

Além dos processos de transferência de calor, ainda são importantes as seguintes propriedades na transferência de calor em coberturas:

- Reflexão: é uma forma de interação da luz com a matéria. Na reflexão, a luz é devolvida ao ambiente sem penetração total na matéria. Superfícies foscas refletem a luz de forma difusa enquanto em superfícies polidas, a luz incidente é refletida em um mesmo ângulo.

- Emissividade: quociente da taxa de radiação emitida por uma superfície pela taxa de radiação emitida por um corpo negro, à mesma temperatura . 
- Absortância: quociente da taxa de radiação solar absorvida por uma superfície pela taxa de radiação solar incidente sobre esta mesma superfície.

- Transmitância: quociente da taxa de radiação solar que atravessa um elemento pela taxa de radiação solar incidente sobre este mesmo elemento.

Em residências horizontais, a maior parte exposta à radiação solar é o telhado que absorve grande parte da energia solar e a transfere para o interior das edificações, aumentando os ganhos térmicos e conseqüentemente, elevando a temperatura interna (MICHELS, 2007).

Segundo Michels, Lamberts e Guths (2006), a radiação solar é composta por radiação de onda curta que aquecem as superfícies das telhas quando são absorvidas pelas mesmas. Parte deste calor absorvido é perdido por convecção e irradiação em ondas longas ao ambiente externo, e a outra parte é absorvida pelas telhas e transmitida ao espaço correspondente ao ático. 0 calor absorvido é transmitido de duas formas: através da irradiação e convecção. Por sua vez, a radiação incidente na superfície da laje (ou forro) é absorvida e a aquece, transferindo o calor para os ambientes internos da residência.

As coberturas geralmente são constituídas de telhado e forro onde ocorrem vários tipos de trocas de calor entre o ambiente externo e interno, conforme apresentado na Figura 2.15. A possibilidade de atuação sobre as parcelas convectivas é limitada, pois esta depende especialmente da incidência de vento, restando como alternativa a atuação sobre as componentes condutiva e radiante (VITTORINO; SATO; AKUTSU, 2003). 


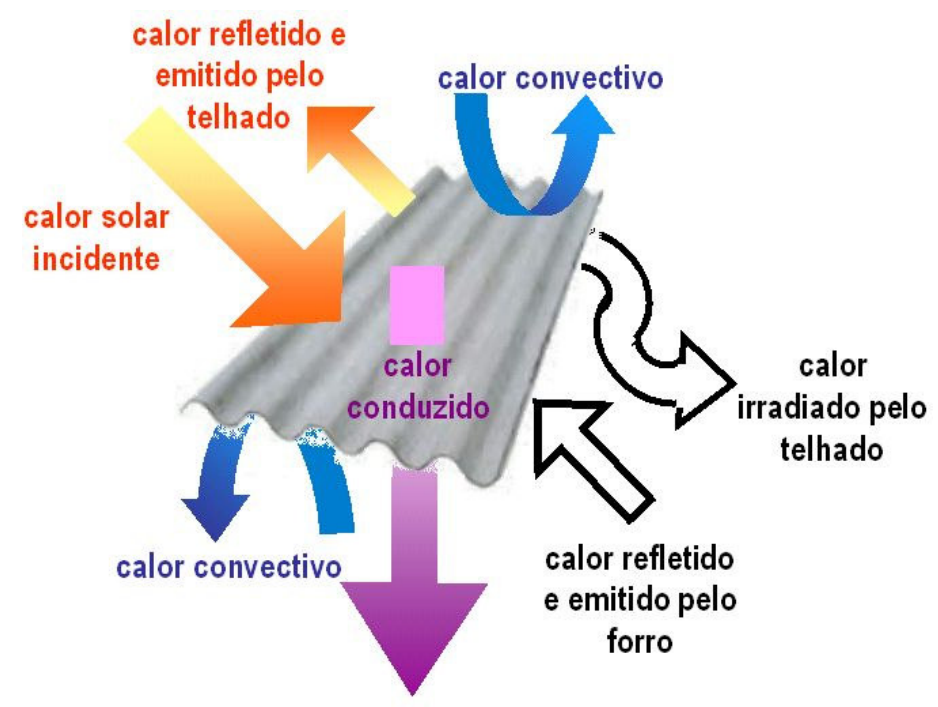

Figura 2.15: Representação de trocas de calor em um telhado.

A utilização de isolantes resistivos, como painéis de fibras minerais ou orgânicas, espumas plásticas rígidas de poliuretano ou poliestireno expandido, etc pode reduzir os ganhos de calor pela cobertura e do calor condutivo (CAMARGO; SATO; PRADO, 2007).

\subsubsection{Tipos de isolantes térmicos}

A Energy Star é um programa da Agência de Proteção Ambiental de EUA (EPA) e do Departamento de Energia dos EUA que ajudam na preservação do meio ambiente através de produtos energeticamente eficientes e com as práticas de conservação de energia.

O programa "Energy Star ${ }^{\circledR}$ Roofs Products" qualifica os produtos chamados "refletivos". Um dos critérios de avaliação é o valor da refletância, que deve ser medida de acordo com a ASTM E 903-96, atualmente cancelada pela ASTM. O valor de refletância deve ser igual ou superior a $65 \%$, este valor indica que $65 \%$ da radiação é refletida pela superfície e que $35 \%$ é absorvida. Para a certificação do produto o valor da refletância não pode ser inferior a $50 \%$ após cinco anos de exposição às intempéries. Os produtos analisados neste trabalho serão analisados de acordo com os critérios da Energy Star para a sua classificação como materiais refletivos (STURDEVANT, 2000). 
A finalidade de isolar termicamente é dificultar a transferência de calor entre dois sistemas que se encontram a níveis diferentes de temperatura. A razão de isolar termicamente é se obter 0 controle máximo das condições térmicas de um meio habitado diante dos agentes térmicos do meio externo (MICHELS, 2007).

Segundo Al-Homoud (2005) o isolamento térmico ocorre quando há a utilização de um material isolado, ou combinado com demais materiais, que aplicados corretamente retardam a passagem do fluxo de calor por condução, convecção e radiação. Esta capacidade de reduzir as trocas de calor é em função da resistência térmica destes materiais.

Dos produtos encontrados no mercado, com propriedades isolantes em coberturas, existem os que dificultam a passagem do calor por condução e os que minimizam a transferência de calor por radiação. As mantas refletivas ou de barreiras radiantes são isolantes formados por um material de baixa emissividade e alta refletividade em ondas longas. As mantas refletivas dificultam a passagem de calor para o interior da edificação, diminuindo os ganhos térmicos no verão e as perdas de calor no inverno, pois têm a função de não emitir e refletir a radiação (MICHELS; LAMBERTS; GUTHS, 2006).

\subsubsection{Revestimentos refletivos: tintas refletivas}

As tintas, como a maioria dos materiais de construção civil, são de natureza não metálica e portanto absorvem grande parte da energia térmica de onda longa incidente e a irradiam novamente para o ambiente (VITTORINO; SATO; AKUTSU, 2003). As tintas podem ser classificadas como "materiais seletivos frios" se apresentarem alta emissividade e alta reflexão à radiação solar (CASTRO, 2005). Na Figura 2.16 são apresentadas as propriedades radiantes de alguns materiais de construção opacos. 


\section{Refletância à radiação solar}

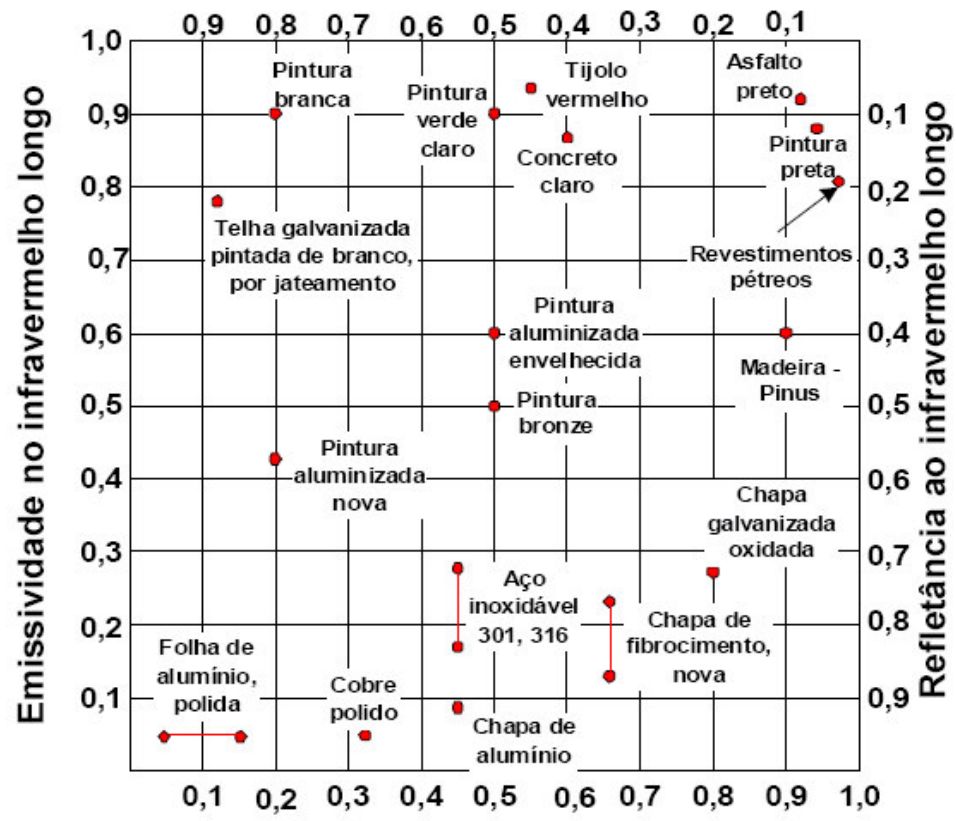

Absortância à radiação solar

Figura 2.16: Propriedades radiantes no espectro da radiação solar e do infravermelho de materiais de construção.

As tintas refletivas têm a finalidade de manter as construções "frias" reduzindo a necessidade do uso do ar-condicionado. Estes revestimentos devem apresentar baixa capacidade de absorção da radiação solar, com redução de temperatura na superfície da telha, e diminuição do calor a ser transferido para o interior da construção (TATUM, 1999). 


\section{TINTAS}

\subsection{Composição básica da tinta}

Com o objetivo de auxiliar a compreensão deste estudo são discutidos a seguir alguns conceitos básicos sobre as tintas. Os conceitos apresentados são voltados para tintas obtidas a partir de emulsões de copolímeros acrílicos, formuladas para decoração e proteção de substratos inorgânicos.

$\mathrm{Na}$ Figura 3.1 observa-se que um mesmo tipo de tinta pode apresentar vários tipos de acabamentos (acetinado, fosco, semibrilho), sendo utilizada em diferentes ambientes como forma de decoração (paredes internas) e de proteção (paredes externas).

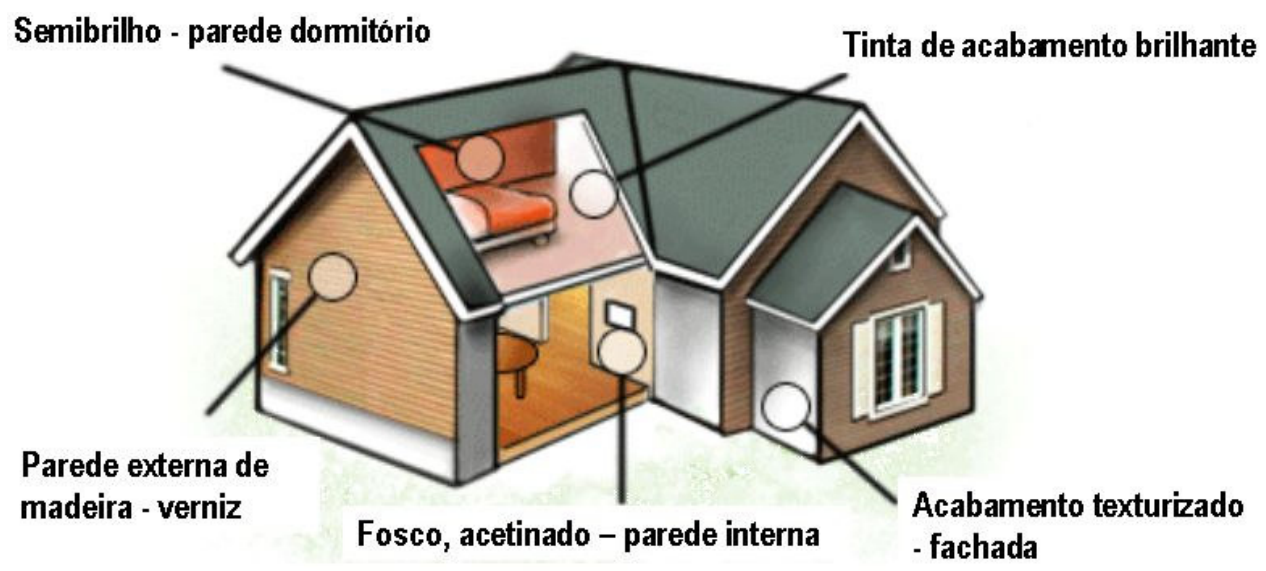

Figura 3.1: Ambientes de uma edificação com diferentes tipos de acabamento para tintas ${ }^{13}$.

A composição e o acabamento da tinta auxiliam na função estética e também na proteção contra agentes externos, como as variáveis climáticas. (CARVALHO; NOGUEIRA, 2005). Conforme apresentado na Figura 3.2, os compostos básicos da tinta são: resinas, pigmentos, solventes e aditivos, sendo que a proporção de distribuição destes compostos varia com o tipo de acabamento que é desejado.

${ }^{13}$ Adaptado do site http://www.specialchem4coatings.com/tc/architectural-paint.aspx, acesso em julho de 2006. 
TINTA BASE SOLVENTE

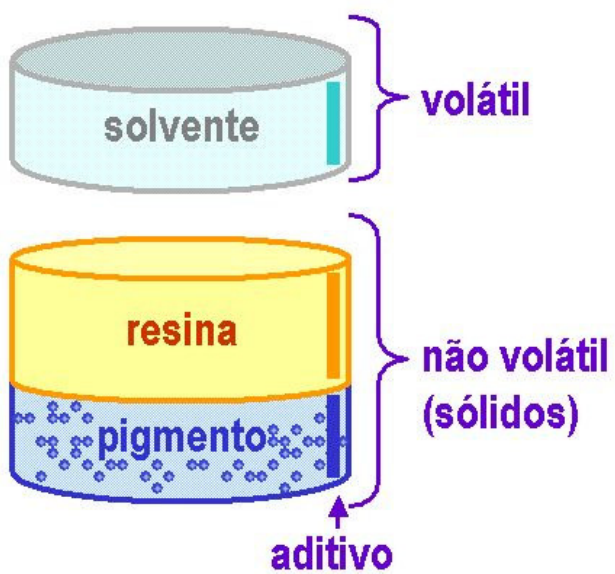

TINTA BASE ÁGUA

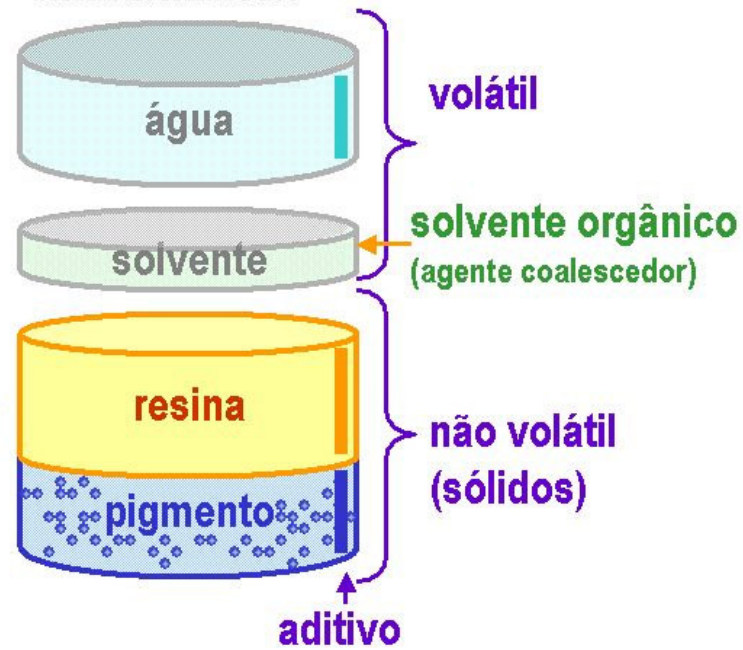

Figura 3.2: Exemplo de composição básica de tintas à base solvente e base água ${ }^{14}$.

\subsubsection{Resina}

A resina é também chamada de veículo não volátil e é o aglutinante das partículas de pigmento, portanto 0 agente formador de filme. A formação da película de tinta está relacionada as reações químicas do sistema polimérico, embora a proporção na composição dos outros componentes como: solventes, pigmentos e aditivos, influenciem na velocidade destas reações (FAZENDA; DINIZ, 2005).

O termo resina foi utilizado inicialmente para descrever as exsudações oleosas que ocorriam nas árvores, como a sintetização das resinas naturais através do processo de polimerização. Por isso que os termos polímero (produto do processo de polimerização) e resina passaram a ser usados como sinônimos (SILVA, 2005; RODOLFO JR. et al., 2002).

Devido à importância dos princípios básicos que regem a formação dos polímeros sintéticos utilizados na fabricação de revestimentos orgânicos, são expostos a seguir alguns conceitos:

- Monômero (do grego monos, que encerra a idéia de unidade, e meros, partes) é a menor molécula que se repete dentro da estruturas molecular de um polímero.

\footnotetext{
14 Figura adaptada da revista Pintura industrial/Sherwin-Williams.
} 
- Polímero é uma substância constituída de moléculas caracterizadas pela repetição múltipla de uma ou mais espécies de átomos ou grupos de átomos. Estes átomos são ligados uns aos outros em quantidades suficientes para fornecer um conjunto de propriedades que não variam acentuadamente com a adição ou a remoção de uma ou algumas unidades constitucionais (ANDRADE, 1995). Na Figura 3.3 é apresentado como exemplo o monômero acrilato e o polímero do poliacrilato.

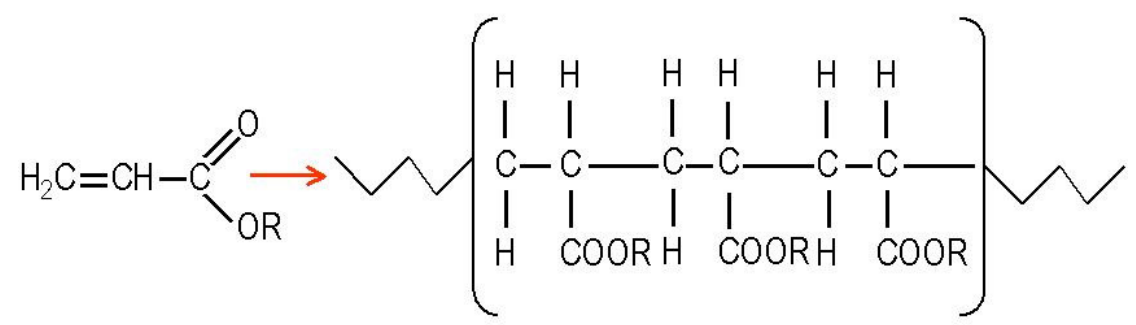

Figura 3.3: Monômero acrilato e polímero do poliacrilato.

- Polimerização é o conjunto de reações químicas intermoleculares, segundo o qual, as moléculas dos monômeros se unem umas a outras, por ligações covalentes para formar polímeros (GUITIÁN, 1994).

- Homopolímero é um polímero resultante da polimerização de uma única espécie monomérica e a sua cadeia é constituída por uma única unidade estrutural repetitiva.

- Copolímero é obtido pela polimerização de duas espécies monoméricas, conseqüentemente a sua cadeia apresenta unidades estruturais resultantes destes monômeros.

Segundo Silva et al (2000), atualmente as tintas encontradas no mercado apresentam na sua maioria resinas do tipo vinílica, acrílica e alquídica:

- Resinas do tipo vinílica são polímeros obtidos através do processo de adição. São processadas a partir de monômeros do tipo vinílico, dos quais destacam-se os acetatos de vinila, cloreto de vinila e o estireno butadieno. 
- Resinas do tipo acrílicas são copolímeros de alto peso molecular com dois ou três tipos de monômeros, sendo um deles, composto acrílico que contém grupos reativos como hidroxila, carboxila ou amida e o outro, um éster acrílico, e um terceiro opcional, que pode ser um monômero do tipo estireno.

- Resinas do tipo alquídica, ou também conhecida como poliéster, são resinas sintéticas usadas como insumo na produção de esmaltes e vernizes da linha imobiliária. E são obtidas pela condensação do anidrido ftálico com poliálcoois e com ácidos graxos superiores saturados ou insaturados (soja, rícino, coco, etc.).

Como foi apresentada anteriormente, a resina é a responsável pela formação de um filme. Segundo Amarilla, Silva Filho e Carbono (2001), alguns fatores que influenciam na formação da película são:

- Umidade relativa: afeta a velocidade de evaporação da água e a porosidade;

- Temperatura: afeta o crosslinking (ligações químicas cruzadas entre cadeias de polímeros) do polímero de tintas epóxi;

- Composição química: a composição do polímero e o seu peso molecular afetam a mobilidade do polímero;

- Fatores externos: a capacidade de absorção da superfície do substrato afeta o processo de saída da água de emulsão (SILVA, 2005).

\subsubsection{Pigmento}

Os pigmentos também são chamados de elementos de cobertura e contribuem na formação da parte sólida de uma camada orgânica. São sólidos com granulometria bastante fina e insolúvel na resina da tinta, sendo responsáveis principalmente pela aparência da película formada.

Os pigmentos conferem cor à tinta, além de conferir opacidade, certas características de 
resistência e outros efeitos (FAZENDA; DINIZ, 2005). Segundo Amarilla, Silva Filho e Carbono (2001) o pigmento além de influenciar as propriedades reológicas da tinta, como a viscosidade e escoamento, também afetam a durabilidade, a resistência e outras propriedades físicas.

O poder de cobertura da tinta é a sua capacidade de encobrir o substrato no qual foi aplicado e que depende basicamente do poder de reflexão e absorção da luz pelos pigmentos constituintes da pintura. Segundo Beeler e Kurz (1993) o potencial de um opacificante também é determinado por essas propriedades, sendo que o índice de refração está associado à estrutura cristalina e 0 tamanho médio do cristal está relacionado ao seu processo de produção.

Essas propriedades como poder de cobertura, viscosidade, etc., podem ser alteradas dependendo da origem do pigmento utilizado. Estas alterações dependem da natureza química do pigmento, da presença de grupos cromóforos, da morfologia das partículas e da disposição, além da dispersibilidade (SILVA, 2005).

\subsubsection{Pigmentos brancos}

Os pigmentos brancos, as cargas e uma grande faixa de pigmentos coloridos (sintéticos ou naturais) são de origem inorgânica. Os principais tipos são os compostos inorgânicos oriundos de antimônio, chumbo, titânio e zinco. Geralmente apresentam índice de refração e opacidade elevada, refletindo e absorvendo a radiação luminosa incidente de uma forma não-seletiva (FAZENDA, 2005; FAZANO, 1995).

A propriedade mais importante de qualquer tipo de pigmento branco é a capacidade dele opacificar e branquear o meio no qual é disperso. 0 potencial opacificante do pigmento é controlado por duas propriedades: índice de refração e tamanho de partícula. 0 índice de refração está associado à estrutura cristalina e, portanto fora do controle do fabricante (ASSIS; ALMEIDA, 2005), enquanto a dimensão da sua partícula pode ser controlada por moagem. A 
Figura 3.4 mostra o efeito do espalhamento através das partículas com diferentes índices de refração, quanto maior o índice, maior o ângulo de deflexão, diminuindo assim a possibilidade da luz atingir o substrato (FAZENDA, 2005).
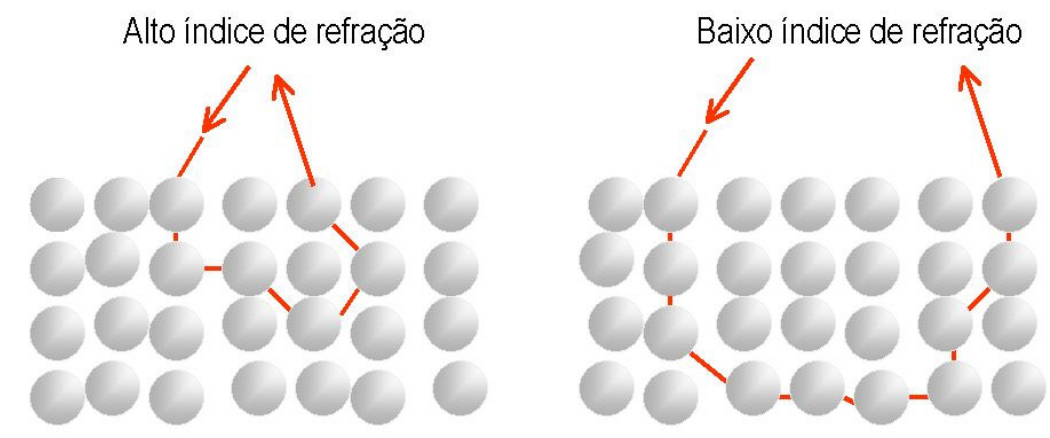

Figura 3.4: Reflexão da luz a partir das partículas de pigmentos.

\subsubsection{Pigmentos coloridos}

Do ponto de vista mercadológico a produção de tintas coloridas é muito importante principalmente devido a sua capacidade de influenciar no aspecto estético.

Os pigmentos brancos refletem a maior parte dos comprimentos de onda da região do visível, enquanto os pigmentos coloridos refletem e absorvem certos comprimentos de onda específicos às cores. Portanto a cor de uma tinta depende do tipo de pigmento que é utilizado na sua composição, e principalmente de como este pigmento reage à exposição aos raios da região do visível (SPENGEMAN, 1995; FAZANO, 1995; PHILLIPS; LEE, 2005).

A percepção visual da cor é influenciada pelas diferentes sensibilidades as cores, que pode variar de pessoa para pessoa. Fatores externos como luminosidade e posição do observador em relação ao objeto, podem apresentar diferenças na determinação das cores. Na Figura 3.5 é apresentado um espectro de cor, mostrando a sua distribuição nos comprimentos de onda de 381 a 780nm, a partir da luz branca (FARKAS, 2001). 


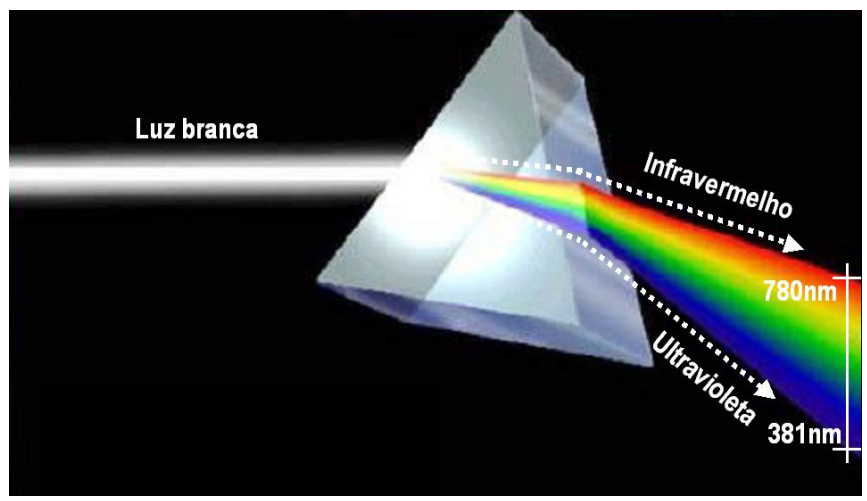

Figura 3.5: Prisma de cor.

$\mathrm{Na}$ luz branca estão contidas todas as cores visíveis, portanto a cor é apenas uma parte da luz branca. Mediante a refração da luz branca em um prisma de cristal se produz o espectro, que é a separação das radiações contidas na luz.

\subsubsection{Solvente}

Os solventes são produtos líquidos e voláteis, geralmente de baixo ponto de ebulição que possuem a capacidade de dissolver a resina sem alterar suas propriedades químicas, conferindo a viscosidade adequada para a sua aplicação. O resultado dessa interação é denominado solubilização; os solventes são líquidos que devem apresentar afinidade química com os materiais a serem dissolvidos (FAZENDA, DINIZ, 2005; UEMOTO, 2002a).

\subsubsection{Aditivos}

Os aditivos são substâncias adicionadas às formulações em pequenos teores e atuam de forma complementar as funções desempenhadas pelos principais componentes sólidos e líquidos da película. Alguns aditivos, como os biocidas, têm ação contra microrganismos biológicos como os aditivos fungicidas, bactericidas, algicidas etc, resultando em aumento da resistência a fungos, bactérias e algas. Outros como os reológicos, podem estabilizar as emulsões, mantendo os pigmentos em suspensão e facilitando a aplicação. Além desses ainda existem os agentes dispersantes e molhantes que auxiliam a produção da tinta, facilitando as interações interfaciais de ar/sólido para líquido/sólido (UEMOTO, 1998). 
Na Tabela 3.1 são apresentados os componentes básicos da tinta e os aditivos normalmente utilizados na sua formulação (MANSHAUSEN, 2001).

Tabela 3.1: Componentes básicos da tinta e aditivos utilizados na formulação.

\begin{tabular}{|c|c|}
\hline Principais componentes da tinta & Aditivos utilizados na formulação \\
\hline Água & Dispersantes e tensoativos \\
Resina & Espessantes e modificadores reológicos \\
Pigmento & Antiespumante \\
Cargas & Biocidas e solventes \\
\hline
\end{tabular}

\subsubsection{Fração volumétrica de pigmentos (PVC)}

A proporção dos componentes constituintes das tintas têm elevada importância nas características de suas pinturas. Um dos parâmetros mais utilizados para descrever 0 proporcionamento ou a composição de uma tinta é a fração volumétrica do pigmento (ou carga), denominada internacionalmente por PVC (termo em inglês que significa pigment volume concentration) (KAIRALLA, 2005). O PVC é a fração volumétrica ocupada pelo pigmento dividido pelo volume da película de pintura seca, também conhecido como veículo sólido, conforme ilustrado pela equação a seguir:

$$
P V C=\frac{V p}{V p+V v} \times 100
$$

Onde:

- Vp: volume de pigmento.

- Vv: volume da película seca.

A Figura 3.6 mostra dois extremos de formulação quanto ao balanceamento da relação PVC. No PVC baixo todas as partículas de pigmento estão envolvidas pela resina; já no $P V C$ alto a quantidade de resina não é suficiente para envolver todas as partículas de pigmento, o que facilita também a aglomeração de partículas dos mesmos. 


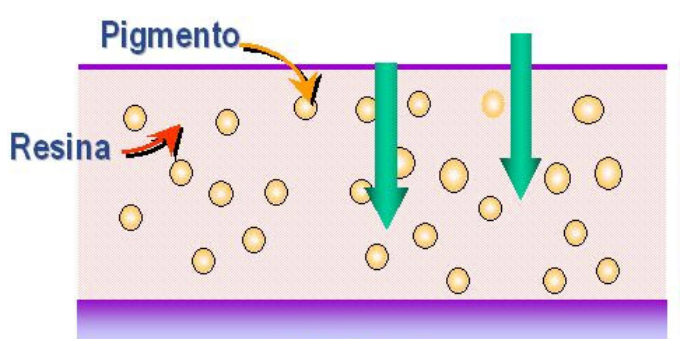

PVC baixo

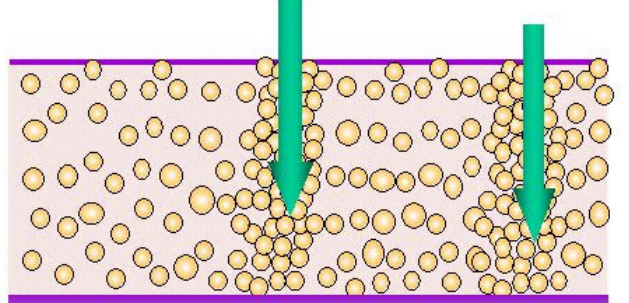

PVC alto

Figura 3.6: Tinta com PVC baixo e alto.

O PVC da tinta é o fator que influencia diretamente em várias propriedades da pintura, e uma delas é o brilho. As tintas foscas possuem um PVC elevado enquanto que uma tinta semibrilho possui um PVC baixo. Na Tabela 3.2 é apresentado a porcentagem do PVC de acordo com 0 tipo de acabamento da tinta.

Tabela 3.2: Tipo de acabamento da tinta em função do PVC ${ }^{15}$.

\begin{tabular}{|c|c|}
\hline Tipo de acabamento & $P V C(\%)$ \\
\hline Alto brilho & 10 a 15 \\
\hline Semibrilho & 15 a 30 \\
\hline Acetinado & 30 a 35 \\
\hline Fosco & 35 a 45 \\
\hline
\end{tabular}

\subsection{Tintas Refletivas}

Apresentados os componentes básicos de uma tinta acrílica; a seguir serão apresentadas as diferenças de uma tinta convencional em relação a uma tinta refletiva com alta refletância na região do infravermelho.

\subsubsection{Resina acrílica}

As pinturas refletivas podem ser susceptíveis à radiação solar, por serem constituídas por polímeros ou copolímeros acrílicos conforme a formulação. Os polímeros acrílicos são os mais utilizados como revestimento de pinturas e tem como característica principal a resistência à radiação solar comparativamente a outros polímeros de mesmo custo.

15 Valores da Tabela 3.2 obtidos nos sites www.specialchem4coatings.com e www.paintquality.com, acesso em novembro de 2006. 
As resinas acrílicas possuem uma grande variedade de monômeros com propriedades variadas. A seleção destes tipos de monômeros para a formulação dos produtos deve ser feita com base nas suas propriedades e com o tipo de aplicação (UEMOTO, 1998). No caso da tinta refletiva, o pigmento usado na sua formulação tem papel decisivo na refletância solar.

\subsubsection{Pigmentos refletivos}

Uma das formas de se obter a tinta refletiva é alterar o tipo de pigmento presente na sua composição. Os pigmentos brancos geralmente apresentam um alto valor de refletância à radiação visível, quando comparado com pigmentos coloridos (NIXON, 2002).

O uso de pigmentos coloridos com alta refletância na região do infravermelho foi iniciado na produção de roupas militares, para auxiliar na camuflagem e minimizar os efeitos da radiação solar nos soldados. Atualmente a indústria de materiais de construção para cobertura estuda a incorporação de pigmentos refletivos coloridos durante a produção das telhas, visando melhorar as propriedades físicas destes componentes e aliá-las as propriedades estéticas (LEVINSON; BERDAHL; ALBARI, 2005).

Como foi apresentada no Capítulo 2, somente a radiação visível é responsável pelas cores dos objetos e é visível ao olho humano; a radiação ultravioleta e a infravermelha são invisíveis. Independente de ser visível ou não, a radiação solar, composta pelas três radiações, aquece as superfícies expostas a ela: quanto mais energia for absorvida pelo material, mais ele se aquecerá.

Dois objetos podem apresentar cores semelhantes, mas propriedades refletivas distintas, como pode ser observado na Figura 3.7. Ambos pigmentos de cor marrom (convencional e refletivo) apresentam temperaturas superficiais diferentes: quanto mais rosa, mais quente. 


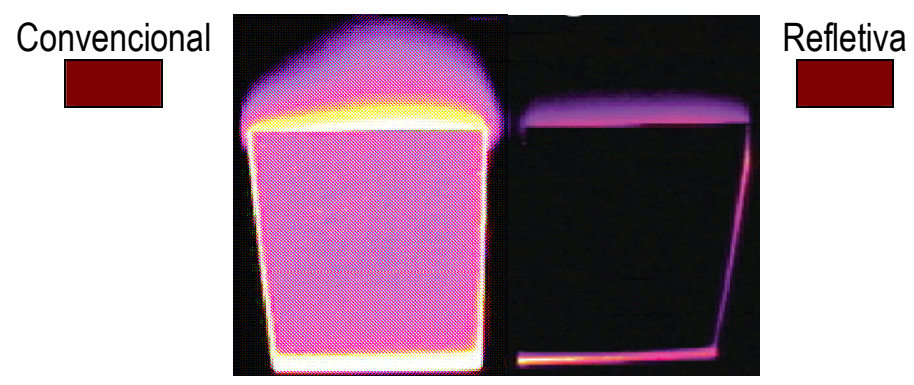

Figura 3.7: Foto de câmera infravermelha do pigmento convencional e refletivo de cor marrom $^{16}$.

O pigmento refletivo tem a capacidade de absorver ou refletir a luz do espectro da região do infravermelho. Esta característica possibilita a refletância da luz infravermelha sem afetar a refletância na região do visível, possibilitando a visualização da cor da película refletiva, semelhante a da tinta convencional.

\subsubsection{Pigmentos cerâmicos}

São pigmentos inorgânicos compostos por óxidos de metal misturados e sintetizados em metal liquefeito (ALMEIDA; ANDRADE, 2005). Os pigmentos sintéticos cerâmicos, segundo um fabricante, são produzidos pela combinação de óxidos ou sais metálicos e calcinados em temperaturas acima de $815,5^{\circ} \mathrm{C}$ até que seus íons sejam incorporados e fixados em estruturas cristalinas tipo rutilo ou spinel.

Os pigmentos cerâmicos são substâncias capazes de oferecer propriedades óticas (cor) em um meio que seja insolúvel e que não haja interação física e/ou química. Existem várias cores de pigmentos cerâmicos disponíveis no mercado e além do aspecto estético, eles ainda apresentam alta refletância na região do infravermelho, resistência ao calor e a ataques químicos.

\subsubsection{Adição de cargas especiais}

Segundo Silva (2005) as cargas são geralmente utilizadas para diminuir o custo total da tinta, e ainda podem conferir-lhes propriedades especiais, como resistência superficial, redução de

\footnotetext{
${ }^{16}$ Adaptado do site www.shepherdcolor.com acesso em fevereiro de 2007.
} 
brilho e resistência ao craqueamento. As principais cargas utilizadas na fabricação de tintas são: carbonato de cálcio, silicato de magnésio, sílica, caulim, sulfato de bário e mica. Além destes tipos de cargas ainda existem aquelas que conferem as tintas, propriedades especiais como a refletância à radiação infravermelha.

\subsubsection{Flocos de alumínio}

Estudos de Smith et al (2003) mostram que é possível alterar a superfície da película de tinta com a adição de flocos de alumínio. A presença destes flocos "orientados" na superfície da película reflete a luz em um ângulo de incidência fixo. A capacidade de aumentar a refletância solar é devida à fina camada de óxido de ferro $\left(\mathrm{Fe}_{2} \mathrm{O}_{3}\right)$ que envolve os flocos de alumínio, já que estes flocos podem refletir a luz infravermelha que é um componente da radiação solar, reduzindo assim, o calor absorvido pela pintura. A distribuição dos componentes, após a adição da carga na película da tinta é apresentado na Figura 3.8.

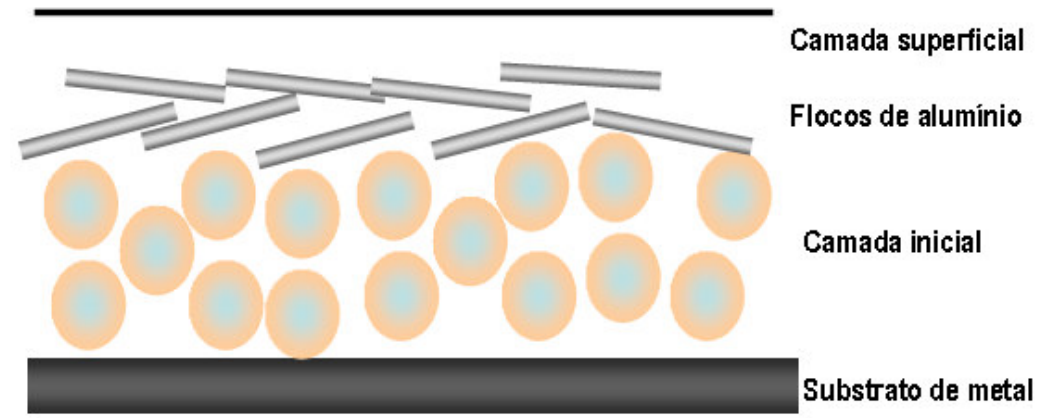

Figura 3.8: Esquema das camadas da pintura contendo flocos de metal (Adaptado de Smith, et al; 2003).

\subsubsection{Microesferas cerâmicas}

Outra carga que pode ser adicionada na composição das tintas são as microesferas cerâmicas (Figura 3.9), elas apresentam tamanhos pequenos e variados, além de alta resistência mecânica. Estes produtos são normalmente utilizados para reduzir os níveis de VOC, aumentar a dureza, resistência à abrasão. De acordo com a estrutura química destes produtos, eles podem ser transparentes, podendo ser adicionados em revestimentos curados por radiação e 
tintas em pó formando películas muito finas.

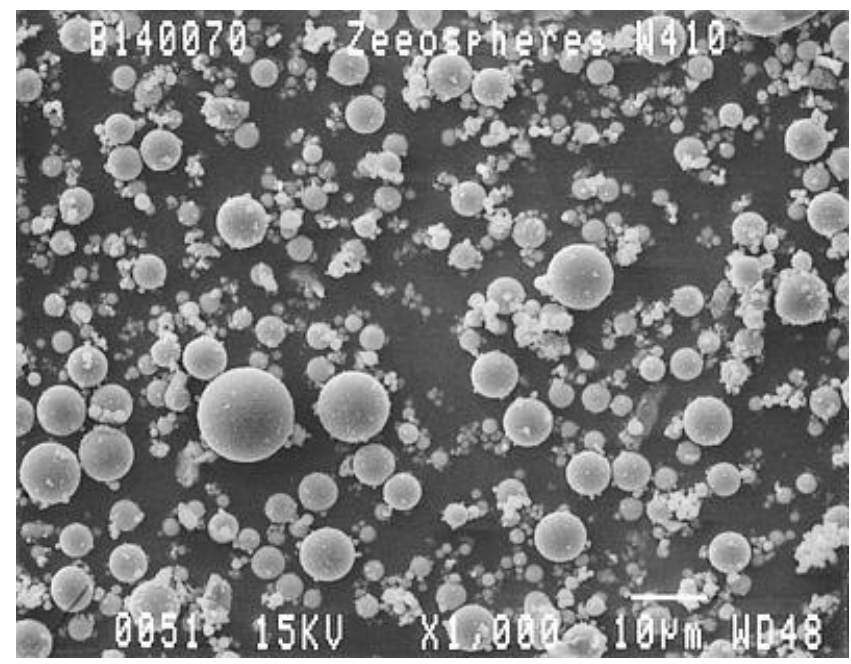

Figura 3.9: Microesfera cerâmica de alta resistência ${ }^{17}$.

Segundo um fabricante nacional, este tipo de carga quando incorporado à tinta, é capaz de refletir, refratar e bloquear o calor, pó, radiação (perda ou ganho) e dissipar o calor rapidamente prevenindo a transferência de calor através do revestimento. Na Figura 3.10 observa-se a disposição das microesferas cerâmicas na película de tinta curada.

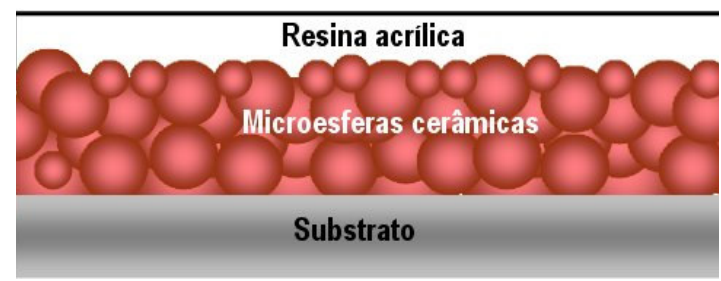

Figura 3.10: Esquema de corte do sistema refletivo, com destaque para a disposição das microesferas cerâmicas.

\subsubsection{Benefícios da utilização de tintas refletivas}

A utilização de tintas refletivas pode melhorar significativamente a temperatura superficial das coberturas das edificações. Estudos realizados no Instituto de Pesquisa Tecnológicas de São Paulo - IPT são apresentados na Figura 3.11, observa-se que é notável a diminuição da temperatura na superfície do material que recebeu a aplicação da tinta refletiva.

${ }_{17}$ Figura obtida no site http://products3.3m.com, acesso em 13/09/2007. 


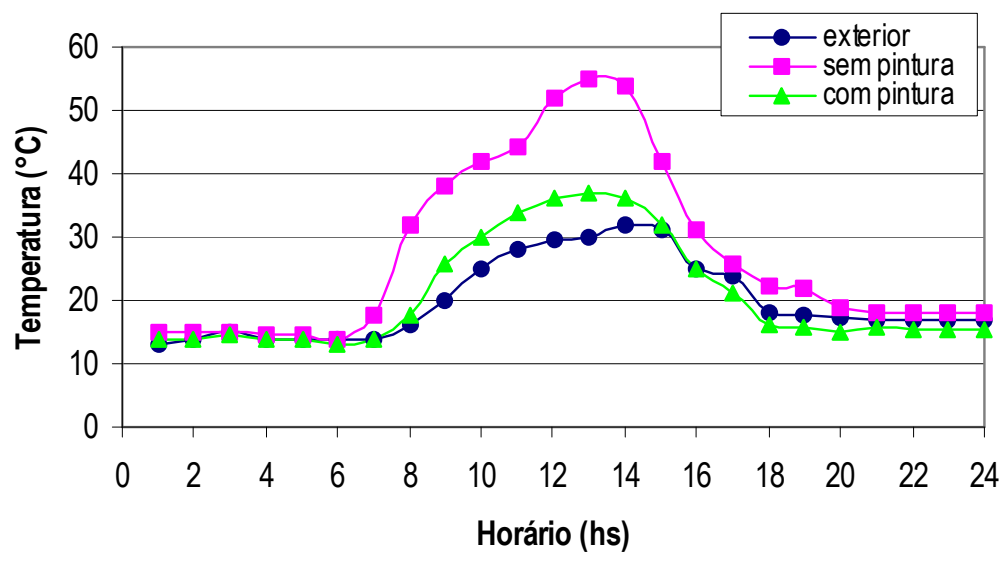

Figura 3.11: Gráfico de variação de temperatura ao longo do tempo'18.

As tintas refletivas quando aplicadas sobre diferentes substratos ajudam a melhorar 0 desempenho térmico destes substratos (CASTRO et al., 2002). Estudos de Synnefa et al. (2005) feitos com 14 amostras de revestimentos refletivos internacionais, confirmam que as tintas refletivas melhoram significativamente o desempenho térmico dos materiais aos quais são aplicadas. Comparando-se a tinta refletiva branca com as tintas convencionais, nota-se que as tintas convencionais embora reduzam a temperatura na superfície, ainda apresentam altas temperaturas no interior das edificações. Materiais de elevada refletância atingem temperaturas mais baixas quando expostos à radiação solar, reduzindo a transferência de calor em seu retorno (FERREIRA; PRADO, 2003).

${ }^{18}$ Dados do gráfico retirados do Relatório Técnico do IPT $n^{\circ}$ 36.823. Na legenda, leia-se: "exterior" a temperatura do ar externo, "sem pintura" temperatura da telha sem pintura e "com pintura" temperatura da telha com pintura refletiva. 


\section{Planejamento Experimental, Materiais e MétọOOS}

\subsection{Etapas da pesquisa}

A pesquisa foi iniciada a partir da revisão bibliográfica com o objetivo de conhecer a atual problemática do meio ambiente, as novas tecnologias e novos materiais construtivos desenvolvidos na área de construção civil como estratégias para a mitigação dos efeitos dos microclimas e das suas conseqüências nos usuários. A revisão bibliográfica mostrou que uma das formas para obtenção do conforto térmico, sem o aumento de energia pode ser através do uso de tintas refletivas formuladas à base de resina acrílica e pigmentos com alta refletância na região do infravermelho.

Do levantamento bibliográfico e dos contatos realizados no mercado brasileiro, foi observada a falta de informações sobre este tipo de material para aplicação em materiais de coberturas, sendo encontrado somente dois produtores de tintas refletivas no Brasil. Os dados obtidos deste levantamento mostraram a necessidade e a importância do desenvolvimento de uma metodologia de avaliação para um sistema telha-tinta que possa ser utilizado nas coberturas das edificações.

A telha de fibrocimento foi escolhida como material de referência para o estudo por ser um tipo de material de cobertura bastante utilizado em edificações brasileiras. Estudos nas fachadas das edificações serão eficazes, se comprovada a eficiência da tinta no seu estado mais crítico: na cobertura das edificações, onde a exposição à radiação solar é mais intensa.

No estudo procurou-se desenvolver uma metodologia para caracterizar uma tinta refletiva quando comparada com uma tinta convencional. Para a realização de uma triagem das tintas 
para o estudo, foram realizados ensaios exploratórios em laboratório de refletância com películas de tintas. Nas amostras selecionadas foram realizados ensaios em laboratório e em campo para a verificação do efeito da radiação infravermelha e da radiação solar nas telhas pintadas com as tintas do estudo.

Os ensaios de determinação de cor e de brilho foram realizados para verificar a correspondência das cores e dos tipos de acabamento das tintas refletivas e convencionais estudadas. A refletância (coeficiente de reflexão) foi determinada com o propósito de observar se as tintas apresentariam diferentes valores de refletância em todo o intervalo de comprimento de ondas do espectro solar.

Para uma avaliação comparativa, os resultados da refletância na radiação visivel foram correlacionados com os resultados do ensaio de determinação de cor, confirmando a correspondência das cores. A análise da refletância à radiação solar foi correlacionada com a temperatura comprovando a influência da refletância no desempenho térmico.

O estudo do efeito da radiação infravermelha na temperatura foi realizado para comprovar se a refletância analisada por análise espectrofotométrica influenciaria na temperatura da telha de fibrocimento pintada com as tintas do estudo. Espera-se que o sistema proposto apresente um alto valor de refletância na região do infravermelho, um desempenho térmico satisfatório e temperaturas superficiais inferiores quando comparado com um sistema com baixo valor de refletância.

A exposição de protótipos ao ambiente natural foi realizada para análise do efeito da radiação solar na temperatura dos protótipos. Estes protótipos estavam expostos no Campus da Escola Politécnica da USP - Departamento de Construção Civil. As medidas de temperatura foram monitoradas durante períodos curtos de exposição. Não foram realizados ensaios de 
envelhecimento natural para avaliação do desempenho térmico ao longo do tempo.

A exposição dos protótipos à radiação solar é importante para correlação com os resultados de exposição à radiação infravermelha simulada por lâmpadas e também com os valores de refletância obtidos por análise espectrofotométrica.

Portanto os ensaios foram escolhidos de modo que os resultados obtidos mostrem as diferenças entre os dois tipos de pintura. Na literatura consultada a maioria dos resultados foram de refletância, não tendo sido analisado o desempenho térmico dos materiais quando expostos à radiação solar e infravermelha. Desta forma espera-se que a análise comparativa das características e das propriedades das tintas e a correlação da refletância com 0 desempenho térmico mostrem a viabilidade do uso deste tipo de pintura na redução da temperatura.

Na Figura 4.1 é apresentado um fluxograma do programa experimental e na Tabela 4.1 são apresentados os ensaios que serão realizados com os respectivos materiais de estudo e a finalidade de cada ensaio. 


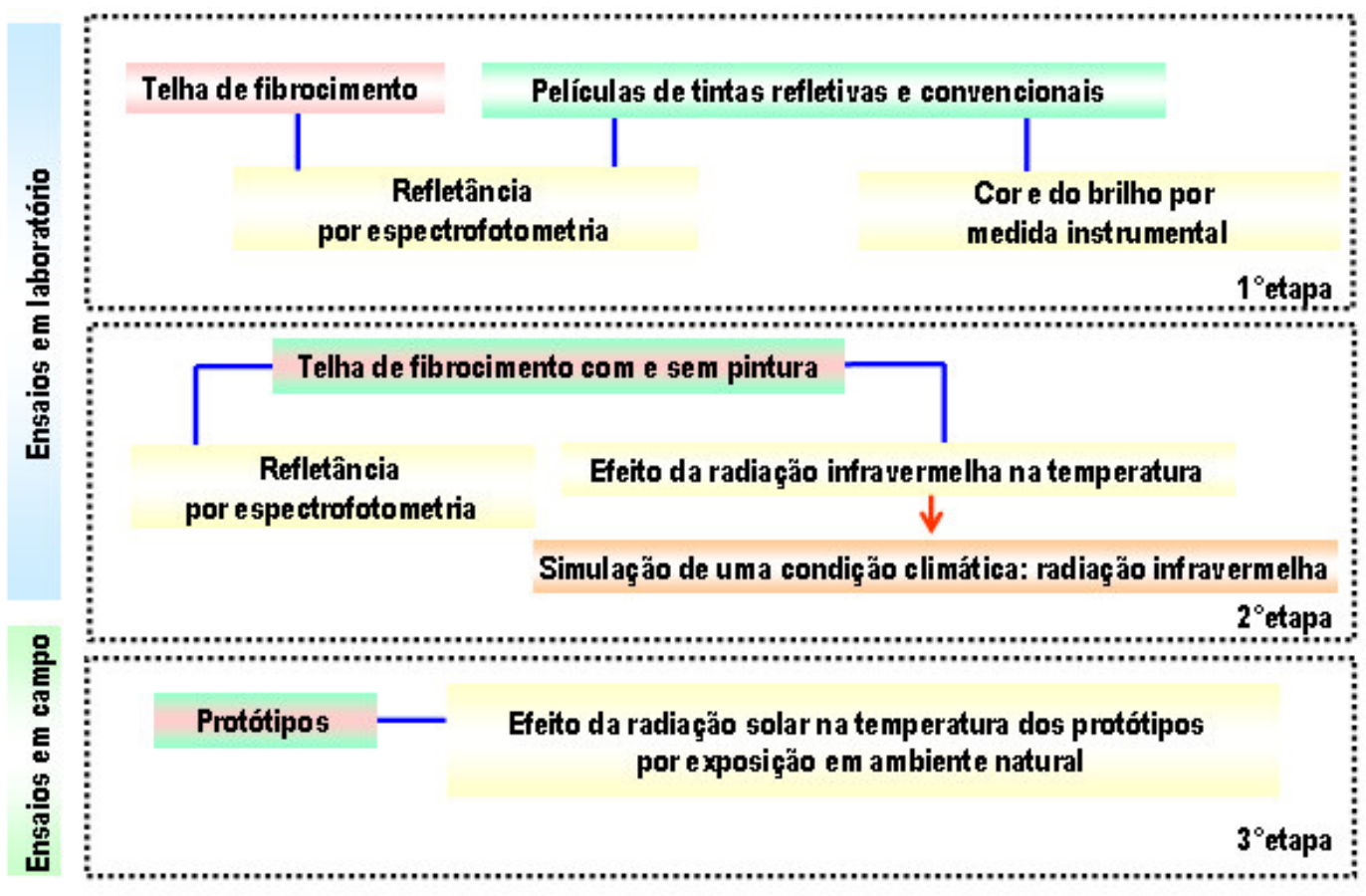

Figura 4.1: Fluxograma do programa experimental.

Tabela 4.1: Ensaios do programa experimental com os respectivos materiais de estudo.

\begin{tabular}{|c|c|c|}
\hline Método de ensaio & Materiais & Finalidade \\
\hline \multicolumn{3}{|c|}{ Ensaio em laboratório } \\
\hline $\begin{array}{l}\text { Refletância por } \\
\text { espectrofotometria }\end{array}$ & $\begin{array}{l}\text { Película de tinta e corpo-de-prova } \\
\text { de telha de fibrocimento com e sem } \\
\text { pintura }\end{array}$ & $\begin{array}{l}\text { Avaliação da } \\
\text { refletância }\end{array}$ \\
\hline Cor por medida instrumental & Película de tinta & $\begin{array}{c}\text { Análise de } \\
\text { correspondência de } \\
\text { cores }\end{array}$ \\
\hline Brilho por medida instrumental & Película de tinta & $\begin{array}{l}\text { Determinação do tipo } \\
\text { de acabamento da } \\
\text { tinta }\end{array}$ \\
\hline $\begin{array}{l}\text { Temperatura em função da } \\
\text { radiação infravermelha }\end{array}$ & $\begin{array}{l}\text { Corpo-de-prova de telha de } \\
\text { fibrocimento com e sem pintura }\end{array}$ & $\begin{array}{l}\text { Correlação entre } \\
\text { refletância e } \\
\text { desempenho térmico }\end{array}$ \\
\hline \multicolumn{3}{|c|}{ Ensaio em campo } \\
\hline $\begin{array}{l}\text { Temperatura em função da } \\
\text { radiação solar por exposição } \\
\text { natural }\end{array}$ & $\begin{array}{l}\text { Protótipos com corpos-de-prova de } \\
\text { telha de fibrocimento com e sem } \\
\text { pintura como cobertura }\end{array}$ & $\begin{array}{l}\text { Correlação entre } \\
\text { refletância e } \\
\text { desempenho térmico }\end{array}$ \\
\hline
\end{tabular}

A seguir são apresentados os materiais utilizados para a realização dos ensaios e a metodologia experimental. 


\subsection{Materiais}

\subsubsection{Tintas e telha de fibrocimento}

A escolha de tintas coloridas refletivas e convencionais de cores correspondentes foi com base no aspecto estético visando a aceitação do produto no mercado pelo consumidor final. Optouse estudar as tintas aplicadas sobre telha de fibrocimento, por ser um componente de cobertura de grande consumo no mercado.

As telhas de fibrocimento utilizadas para o estudo são de fabricação do Grupo Infibra. As telhas foram fabricadas pelo processo hatschek, produzidas com uma tecnologia sem amianto e são constituídas por cimento calcário, sílica ativa, fibras de PVA $(6 \mathrm{~mm})$ e fibras de celulose (curtas e longas). As telhas de fibrocimento para o estudo apresentam as seguintes dimensões: $1,22 \mathrm{~m}$ de comprimento e $6 \mathrm{~mm}$ de espessura.

Foram selecionadas para o estudo amostras de tintas do mercado, declaradas pelo fabricante como refletivas e tintas acrilicas convencionais para fachadas. Na Tabela 4.2 é apresentada a relação das películas para realização dos ensaios de laboratório.

Tabela 4.2: Relação das tintas estudadas.

\begin{tabular}{|c|c|c|}
\hline Tinta & Cor & Característica \\
\hline T1 & Branca & Refletiva \\
\hline T2 & Marrom & \\
\hline T3 & Amarela & Convencional para fachadas \\
\hline T4 & Branca & Convencional com propriedades auto-limpantes \\
\hline T5 & Marrom & Refletiva nacional \\
\hline T6 & Amarela & Refletiva internacional \\
\hline T7 & \multirow{2}{*}{ Alumínio } & Refletiva com microesferas de vidro ocas \\
\cline { 1 - 1 } T8 & \multirow{2}{*}{ Branca } & Refletiva com microesferas cerâmicas \\
\hline T19 & & \\
\cline { 1 - 1 } T10 & &
\end{tabular}

Algumas características químicas fornecidas pelos fabricantes dos produtos e a composição básica das tintas do estudo e são apresentadas respectivamente na Tabela 4.3 e na Tabela 
4.4. As tintas apresentam em suas composições: água, glicóis e solvente, além de aditivos específicos. As tintas T2 e T3 apresentam pigmentos sintéticos cerâmicos em sua composição e as tintas T9 e T10 apresentam cargas especiais de microesferas de vidro e microesferas cerâmicas.

Tabela 4.3: Características químicas das tintas.

\begin{tabular}{|c|c|c|c|}
\hline Tinta & $\begin{array}{c}\text { Sólidos } \\
\text { (\% peso) }\end{array}$ & PVC (\%) & $\begin{array}{c}\text { Densidade } \\
\text { (g/cm3) }\end{array}$ \\
\hline T1 & 59 & 68 & 1,5 \\
\hline T2 & 59 & 68 & 1,5 \\
\hline T3 & 59 & 68 & 1,5 \\
\hline T4 & 48 & 30 & 1,27 \\
\hline T5 & 47 & 36 & 1,32 \\
\hline T6 & 44 & 36 & 1,26 \\
\hline T7 & 20 & 15 & 1,04 \\
\hline T8 & 10,2 & - & 1,05 \\
\hline T9 & \multicolumn{4}{|c|}{58} & 81 & 1,22 \\
\hline T10 & \multicolumn{3}{|c|}{ não fornecido pelo fabricante } \\
\hline
\end{tabular}

Tabela 4.4: Composição básica das tintas.

\begin{tabular}{|c|c|c|}
\hline Tinta & Polímero base & Pigmentos e cargas \\
\hline T1 & $\begin{array}{l}\text { dispersões estireno-acrílica e } \\
\text { silicone }\end{array}$ & dióxido de titânio, silicas, carbonato de cálcio e mica \\
\hline $\mathrm{T} 2$ & $\begin{array}{l}\text { dispersões estireno-acrílica e } \\
\text { silicone }\end{array}$ & cerâmico marrom, silicas, carbonato de cálcio e mica \\
\hline T3 & $\begin{array}{c}\text { dispersões estireno-acrílica e } \\
\text { silicone }\end{array}$ & cerâmico amarelo, silicas, carbonato de cálcio e mica \\
\hline $\mathrm{T} 4$ & $\begin{array}{l}\text { dispersão estireno-acrílica } \\
\text { modificada }\end{array}$ & $\begin{array}{c}\text { dióxido de titânio, silica, caulim e esferas de vidro } \\
\text { maciças }\end{array}$ \\
\hline T5 & dispersões estireno-acrílica & $\begin{array}{l}\text { dióxido de titânio, caulim, carbonato deálcio, óxidos de } \\
\text { ferro vermelho e amarelo e preto de carbono }\end{array}$ \\
\hline T6 & dispersões estireno-acrílica & $\begin{array}{l}\text { dióxido de titânio, caulim, carbonato deálcio, óxidos de } \\
\text { ferro vermelho e amarelo orgânico }\end{array}$ \\
\hline $\mathrm{T} 7$ & $\begin{array}{l}\text { dispersão estireno-acrílica } \\
\text { modificada }\end{array}$ & Alumínio \\
\hline T8 & não conhecido & Alumínio \\
\hline T9 & $\begin{array}{c}\text { dispersões estireno-acrílica e } \\
\text { silicone }\end{array}$ & $\begin{array}{c}\text { dióxido de titânio, silica, carbonato de álcio, mica e } \\
\text { esferas de vidro ocas }\end{array}$ \\
\hline T10 & $\begin{array}{l}\text { polímeros elastoméricos de } \\
\text { acrílico puro }\end{array}$ & $\begin{array}{c}\text { pigmentos, microesferas de cerâmica sintética e cargas } \\
\text { minerais ativas }\end{array}$ \\
\hline
\end{tabular}


Os corpos-de-prova foram preparados de duas formas para o estudo:

- Películas "livres": as películas foram obtidas através da aplicação da tinta sobre um filme de teflon, com auxílio de um pincel. As películas foram secas em ambiente climatizado com temperatura de $25 \pm 5^{\circ} \mathrm{C}$ e umidade relativa de $50 \pm 10 \%$ e separadas do filme de teflon após sete dias de cura. Na Figura 4.2 é apresentado o aspecto da película "livre" sem o substrato.

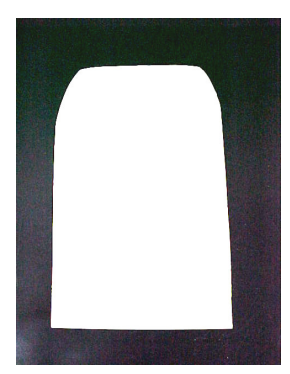

Figura 4.2: Aspecto da película "livre".

- Tintas aplicadas em telhas de fibrocimento: as tintas foram aplicadas em 2 demãos de tinta com rolo de lã de carneiro e em intervalos de 4 horas sobre a telha de fibrocimento. Os corpos-de-prova foram secos a temperatura de $25 \pm 5^{\circ} \mathrm{C}$ e umidade relativa de $50 \pm 10 \%$. Os corpos-de-prova apresentam as seguintes dimensões:
a) $4 \times 2 \mathrm{~cm}$,
b) $14 \times 16 \mathrm{~cm}$
c) $1,22 \times 1,50 \mathrm{~m}$ (tamanho original)

Na Figura 4.3 são apresentadas as telhas de fibrocimento utilizadas como cobertura para os protótipos e na Figura 4.4 são mostrados os procedimentos de obtenção dos corpos-de-prova para o ensaio de determinação da refletância. Na Tabela 4.5 é apresentada a relação dos protótipos expostos em ambiente natural, de acordo com o seu tipo de cobertura. 

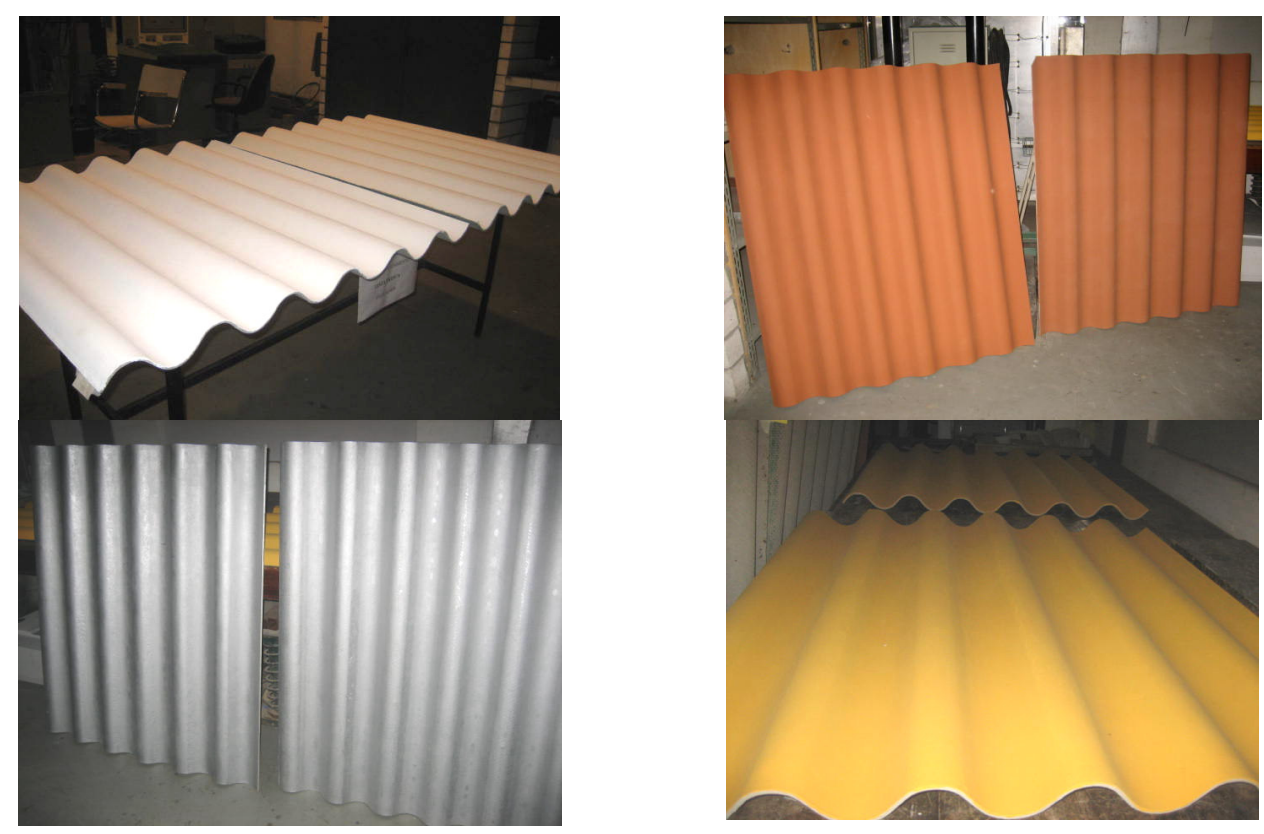

Figura 4.3: Telhas de fibrocimento após receberem pintura.

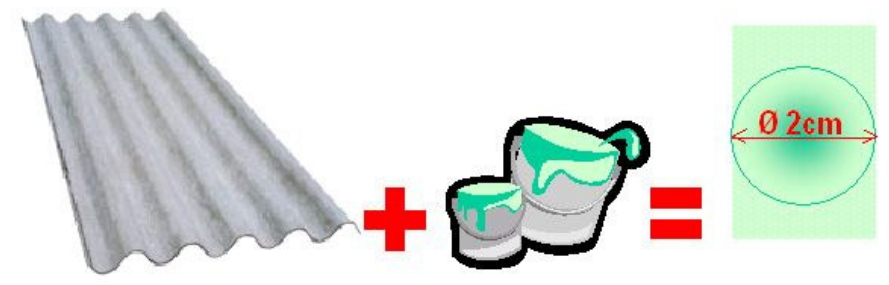

Figura 4.4: Esquema de produção dos corpos-de-prova para o ensaio de refletância.

Tabela 4.5: Relação dos protótipos utilizados no ensaio em campo.

\begin{tabular}{|c|c|c|}
\hline Protótipo & Tipo de cobertura & Característica \\
\hline REF & Sem pintura & Telha de fibrocimento \\
\hline P1 & REF + T1 & Pintura branca refletiva \\
\hline P2 & REF + T2 & Pintura marrom refletiva \\
\hline P3 & REF + T3 & Pintura amarela refletiva \\
\hline P4 & REF + T4 & Pintura branca convencional \\
\hline P5 & REF + T5 & Pintura marrom convencional \\
\hline P6 & REF + T6 & Pintura amarela convencional \\
\hline P7 & REF + T7 & Pintura refletiva alumínio nacional \\
\hline P8 & REF + T8 & Pintura refletiva alumínio internacional \\
\hline P9 & REF + T9 & Pintura branca refletiva com microesferas de vidro \\
\hline P10 & REF + T10 & Pintura branca refletiva com microesferas cerãmica \\
\hline
\end{tabular}

\subsection{Métodos}

\subsubsection{Determinação da cor por medida instrumental}

A cor das películas de tinta foi determinada através da medida instrumental, de acordo com a 
"NBR 15077 - Método para avaliação de desempenho de tintas para edificações não industriais - determinação da cor e da diferença de cor por medida instrumental". O iluminante (fontes de luz padrão) utilizado no ensaio foi o D65, que simula a luz média do dia. Foram realizadas dez leituras em cada película de tinta, sendo apresentado o valor médio dos valores obtidos.

Para a determinação de cor foi utilizado o espectrofotômetro computadorizado Color-Guide com geometria direcional $45^{\circ} / 0^{\circ}$ (Figura 4.5) e o programa para cálculo CIELAB. O CIE (Commission Internacionale de l'Éclairage) padronizou a fonte de luz pela quantidade de energia emitida a cada comprimento de onda e que eqüivale ao poder de distribuição espectral relativa.

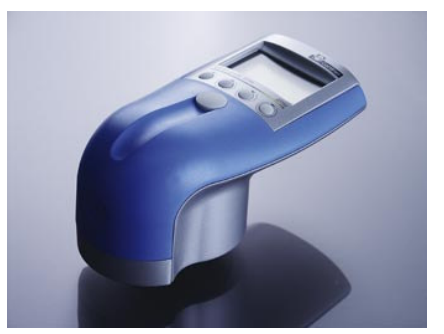

\section{Figura 4.5: Colorímetro - Byk Gardner.}

\subsubsection{Definições}

- Triestímulos XYZ: o aparelho detecta três funções de onda que representam a sensibilidade do olho humano para as cores primárias (vermelho, verde, azul).

- CIE L*a*b*: sistema de cores desenvolvido pela Comissão Internacional de lluminação (CIE), conforme apresentado na Figura 4.6 para quantificar cores, baseado nas coordenadas:

a) $L^{*}$ : escala de preto a branco, com valores de 0 (preto) à 100 (branco).

b) a*: escala de vermelho a verde, com valores positivos para cores avermelhadas e, negativos para cores esverdeadas.

c) b*: escala de amarelo a azul, com valores positivos para cores amareladas e, negativos para cores azuladas. 


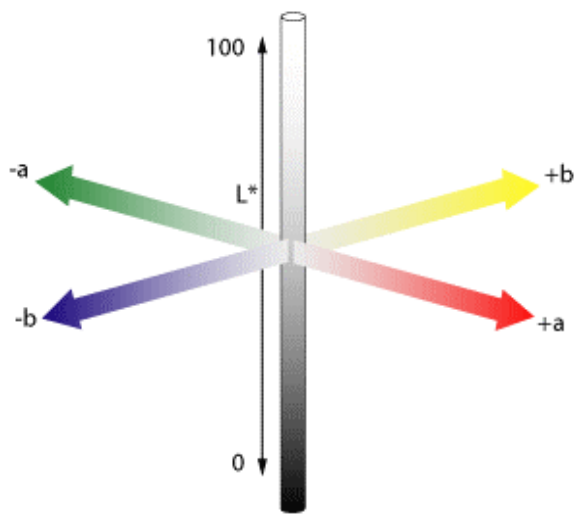

Figura 4.6: Gráfico do CIE L*a*b*, sistema de cores desenvolvido para quantificar cores.

- Iluminantes: fontes de luz padrão, utilizadas no espectrofotômetro para simulação das condições reais de observação, como a luz média do dia (iluminante D65, vide Figura 4.7), a luz incandescente produzida por lâmpadas de filamento de tungstênio (iluminante A) e a luz fluorescente produzida por lâmpadas de vapor de mercúrio (iluminante CWF)

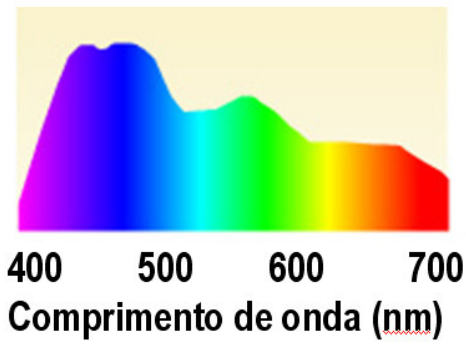

Figura 4.7: Gráfico de iluminante D65.

\subsubsection{Determinação do brilho}

O método de avaliação consiste em dirigir um feixe de luz de um determinado ângulo sobre a superfície, e medir a intensidade do feixe refletido com uma célula fotoelétrica. 0 ensaio foi realizado em películas conforme diretrizes da norma "NBR 15299 - Tintas para construção civil - Método para avaliação de desempenho e tintas para edificações não industriais determinação de brilho".

A medida do brilho foi realizada com um "Glossmeter" tipo Byk Gardner - GB4520 (Figura 4.8) 
usando geometria $60^{\circ}$, geralmente utilizados para acabamentos semibrilho. Conforme as normas os ensaios devem ser iniciados usando angulo de $60^{\circ}$, para valores de unidades de brilho (UB) superiores a 70 UB o ensaio deve ser repetido com ângulo de $20^{\circ}$ e para valores inferiores a 10 UB o ensaio deve ser repetido com ângulo de $85^{\circ}$. As medidas foram realizadas a $60^{\circ}$, para cada película de tinta foram realizadas três leituras, sendo apresentado como resultado, a média destas leituras.

O brilho de superfícies pintadas varia de acordo com o ângulo de incidência de maneira que, para se obter uma completa descrição do brilho das películas a determinação é feita sob vários ângulos, vide Figura 4.9 (SILVA, 2005).

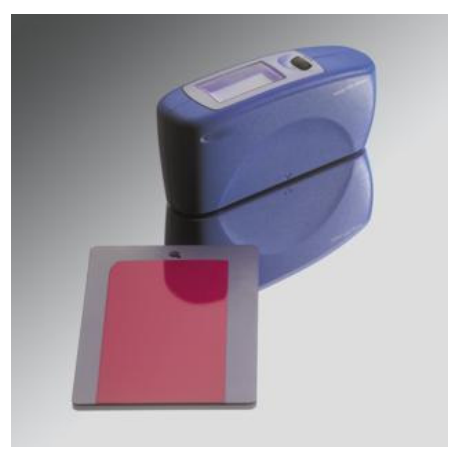

Figura 4.8: Medido de brilho - Byk-Gardner.

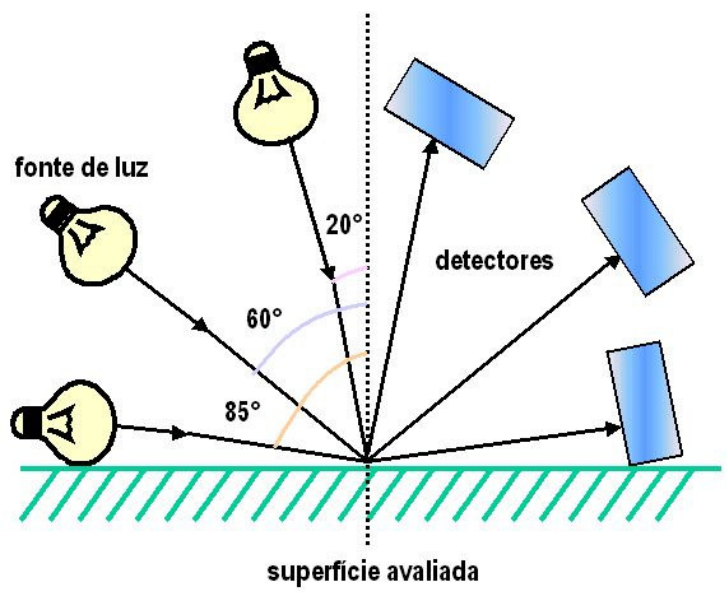

Figura 4.9: Ângulos de leitura para medida de brilho.

\subsubsection{Determinação da refletância por espectrofotometria}

O ensaio foi realizado de acordo com "ASTM-E903(96): Standard test method for solar 
absorptance, reflectance, and transmittance of materials using integrating spheres". As medidas foram determinadas no espectrofotômetro com esfera integradora.

O equipamento utilizado para a leitura da refletância foi o espectrofotômetro da marca Shimadzu, modelo UVPC 3101 PC com esfera integradora IRS 3100, conforme apresentado na Figura 4.10.

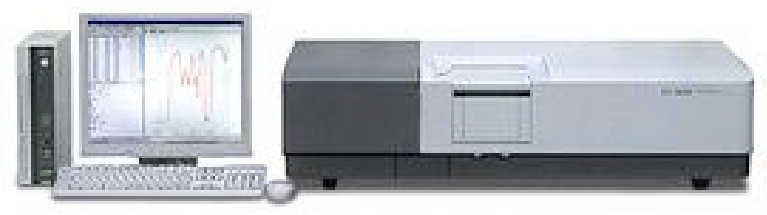

Figura 4.10: Espectrofotômetro UV 3101PC com esfera integradora - Shimadzu.

Foram analisadas as faixas que compreendem os espectros solares: ultravioleta, visível e infravermelho através da refletância especular difusa, devido à irregularidade das superfícies estudadas. Foram realizadas cinco leituras de refletância para cada película e corpo-de-prova das tintas do estudo, sendo apresentado como resultado a média aritmética dos resultados.

O acoplamento da esfera integradora ISR-3100 (60 mm de diâmetro) no equipamento permite a medição de amostras sólidas, possibilitando medições de refletância absoluta de alta exatidão. A esfera integradora é usada principalmente para medição de refletância difusa/especular e medição de transmissão de amostras líquidas e sólidas. 0 acessório possui uma ampla faixa de comprimento de onda, de $240 \mathrm{~nm}$ até 2600 e é equipado com o fotomultiplicador e célula de sulfeto de chumbo (PbS).

Na Figura 4.11 é apresentado o esquema para a leitura de refletância. Quando luz é direcionada na amostra a $0^{\circ}$ é medida a refletância difusa, e quando luz é direcionada em $8^{\circ}$ é medida a refletância total (refletância especular e difusa). 


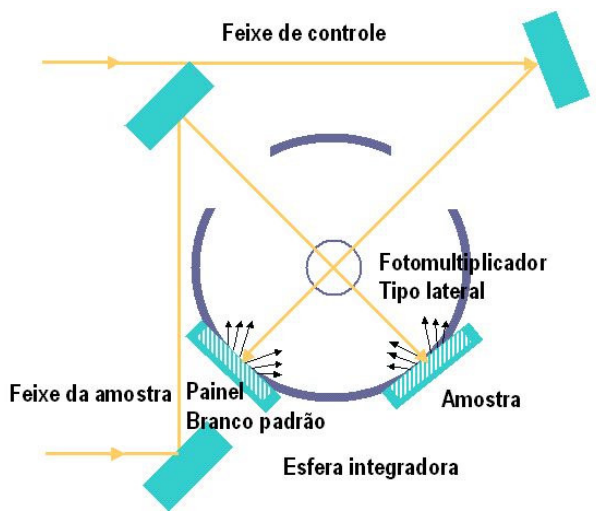

Figura 4.11: Esquema de medição de amostra opaca usando o método de esfera integradora.

\subsubsection{Parâmetros para ensaio de refletância}

Os parâmetros utilizados para realização do ensaio de refletância difusa são apresentados a seguir:

- Método de leitura: refletância espectral

- Intervalo espectral: 200 a $2600 \mathrm{~nm}$

- Velocidade: $1600 \mathrm{~nm} / \mathrm{min}$ (intervalo de $2 \mathrm{~nm}$ )

- Espessura de fenda: $8 \mathrm{~mm}$

- Velocidade de varredura: rápida

- Intervalo de leitura do intervalo de onda: automático

- S/R: normal (leitura de refletância difusa)

\subsubsection{Calibração do equipamento}

O sulfato de bário $\left(\mathrm{BaSO}_{4}\right)$ foi utilizado como referência por ser um material que apresenta uma refletância de aproximadamente $100 \%$ em todo o espectro. A calibração do equipamento foi realizada utilizando este material em pó, comprimido em forma de pastilhas, fornecido pelo fabricante do equipamento. 
$\mathrm{O} \mathrm{BaSO}_{4}$ foi colocado nos dois compartimentos de leitura: para a referência e para a amostra. Após a calibração da curva padrão, uma das pastilhas de sulfato de bário é retirada e substituída pelas amostras do estudo, como indicado na Figura 4.12.

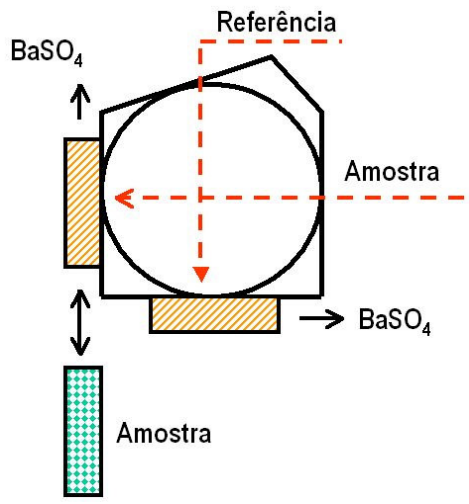

Figura 4.12: Sistema ótico da medição difusa (Adaptado do Manual de Instruções do espectrofotômetro UVPC 3101).

\subsubsection{Cálculo da refletância}

Os valores de refletância foram calculados pelo método de integração de áreas. O software do equipamento calcula a área integrada, abaixo da curva de reflexão especular de cada amostra conforme apresentado na Figura 4.13. Utilizou-se este método para o cálculo da área das amostras de referência (que apresentavam uma refletância aproximada de 100\%) e para as áreas integradas abaixo das curvas de cada amostra do estudo.

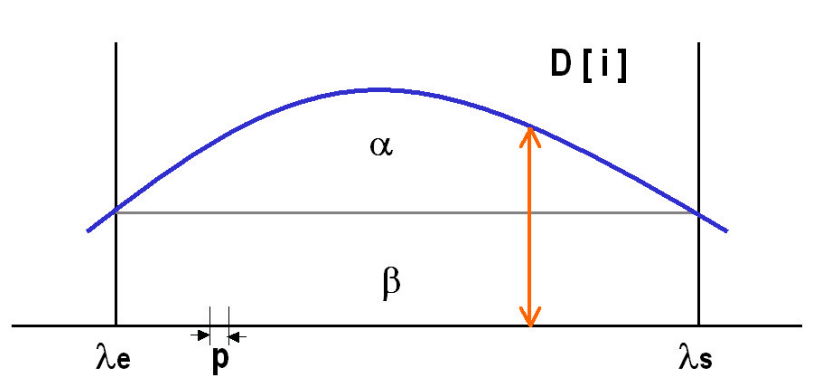

$$
\begin{aligned}
& \alpha+\beta=\left(\sum_{i=\lambda s}^{\lambda e-p} D[i]\right) * P \\
& \beta=\frac{1}{2} *(D s+D e) *(\lambda e-\lambda s) \\
& \mathrm{R}(\%)=\text { área das amostras } \\
& \text { área do padrão de } \mathrm{BaSO}_{4}
\end{aligned}
$$

Figura 4.13: Diagrama para o cálculo de área integrada.

A refletância é obtida através da divisão dos valores da área das amostras do estudo pela área da amostra padrão de sulfato de bário $\left(\mathrm{BaSO}_{4}\right)$. 


\subsubsection{Efeito da radiação infravermelha na temperatura de corpos-de-prova}

Para determinação da temperatura dos corpos-de-prova de fibrocimento com e sem pintura foi construído um equipamento para exposição dos corpos-de-prova à radiação infravermelha. Foram expostos dois corpos-de-prova, simultaneamente à radiação infravermelha, sendo apresentada uma curva média de temperatura.

Os corpos-de-prova foram expostos à radiação infravermelha obtida por lâmpadas infravermelhas de secagem de $250 \mathrm{~W}$ da marca Philips. Estas lâmpadas de radiação infravermelha convertem a energia elétrica em raios infravermelhos que se propagam da mesma forma que a luz, sem perda considerável de energia. Toda a radiação infravermelha emitida pelas lâmpadas é transformada imediatamente em calor ao incidir sobre as superfícies dos corpos-de-prova.

Conforme apresentado na Figura 4.14, o equipamento consistia em um compartimento de madeira compensada retangular, com lâmpadas de radiação infravermelha presas no topo de um suporte. Para determinação da distância ideal entre a lâmpada e a superfície a telha de fibrocimento sem pintura houve a monitorização da temperatura durante uma hora e meia de exposição. Os resultados dos testes de temperatura em função da distância entre a lâmpada e a superfície da telha estão apresentados na Tabela 4.6. A distância definida depois da realização dos testes foi de $20 \mathrm{~cm}$, onde a temperatura média obtida foi de $80 \pm 10^{\circ} \mathrm{C}$.

Tabela 4.6: Resultados dos testes de temperatura.

\begin{tabular}{|c|c|c|}
\hline $\begin{array}{c}\text { Distância } \\
(\mathrm{cm})\end{array}$ & $\begin{array}{c}\text { Temperatura } \\
\left({ }^{\circ} \mathrm{C}\right)\end{array}$ & Tempo $(\mathrm{h})$ \\
\hline 10 & $120 \pm 20$ & 1,5 \\
\hline 20 & $80 \pm 10$ & 1,5 \\
\hline 50 & $50 \pm 5$ & 1,5 \\
\hline 80 & $30 \pm 3$ & 1,5 \\
\hline
\end{tabular}



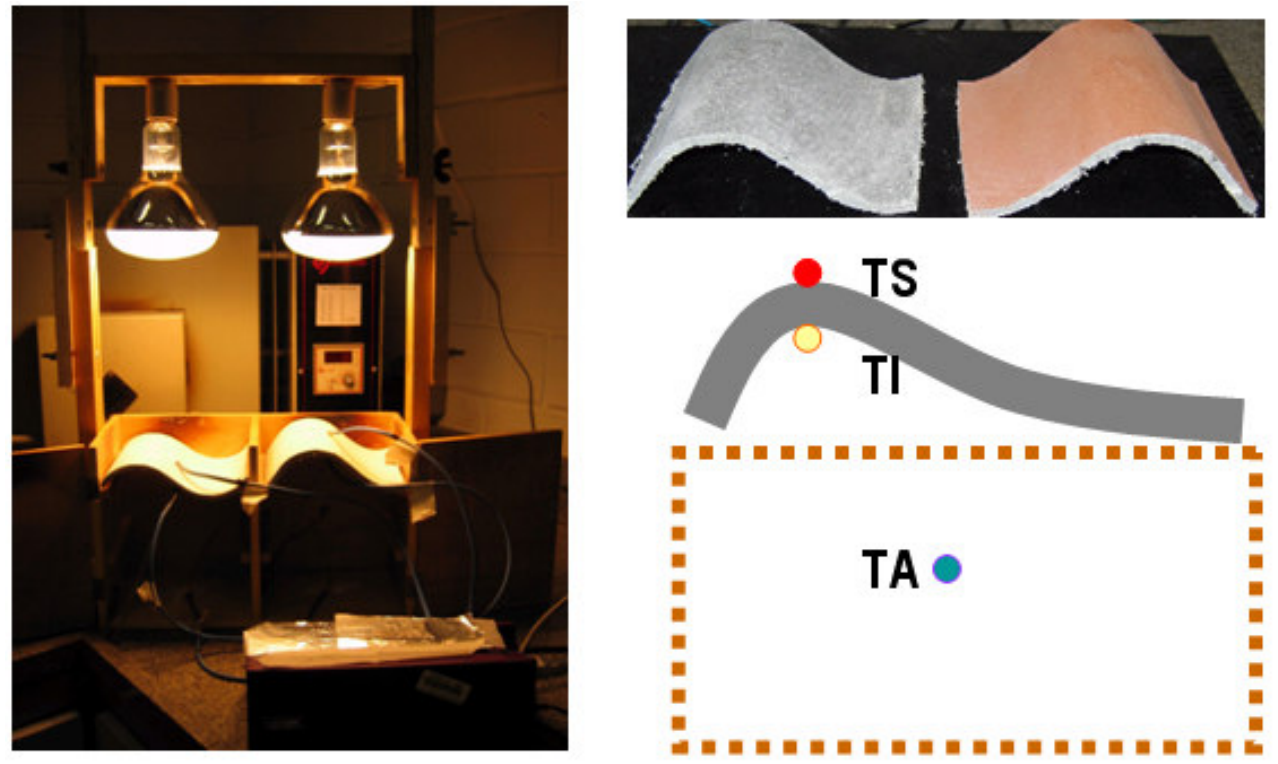

Figura 4.14: Esquema final do equipamento adaptado para exposição à radiação infravermelha.

A temperatura foi determinada por meio de termopares tipo $\mathrm{T}$, confeccionados com cabos de compensação de cobre e constantan, na região abaixo das telhas, na superfície inferior e na superior. Os termopares foram posicionados da seguinte forma:

- Superfície dos corpos-de-prova (TS): foram colados na superfície do corpo-de-prova. 0 termopar foi pintado com a mesma tinta da telha de fibrocimento, para que a temperatura medida fosse da telha e não do próprio termopar.

- Face inferior dos corpos-de-prova (TI): foram colados na face inferior do corpo-deprova. A colocação deste termopar foi necessária para mostrar as diferenças de temperaturas medidas entre a superfície da telha de fibrocimento e a temperatura da face interna da telha.

- Interior do equipamento (TA): foram colocados na região abaixo do corpo-de-prova.

Para garantir uma potência constante da lâmpada de radiação infravermelha durante todo 0 ensaio foi determinado um ciclo de exposição, onde as telhas de fibrocimento sem pintura (utilizadas como referência) foram intercaladas entre a exposição das demais tintas do estudo. 
Somente após a análise da temperatura da referência, o próximo grupo era exposto à radiação infravermelha.

Os dados obtidos por termopares foram registrados através do DataTaker modelo DT800 e enviados para o computador pelo software Detransfer. As leituras de temperatura eram armazenadas a cada 60 segundos. 0 período de exposição foi determinado com base em um ensaio com 12 horas de exposição dos corpos-de-prova à radiação infravermelha. Como não foram observadas alterações de temperatura durante o período de 1 hora de exposição determinou-se o tempo de exposição de 1 hora e meia.

\subsubsection{Ensaio em campo: efeito da radiação solar na temperatura de protótipos expostos em ambiente natural}

O período de exposição dos protótipos foi definido com base nos trabalhos de Camargo, Sato e Prado (2007), onde os seguintes critérios foram utilizados:

- Apresentar características de medição estáveis, com repetição das características observadas durante vários dias, o que permite afirmar que os dados considerados representam o comportamento térmico dos protótipos e não um fenômeno isolado que tenha ocorrido por interferência de uma variável incomum.

- Conter dois dias que representam o dia típico de projeto de verão em São Paulo, com freqüência de ocorrência de 10\% (AKUTSU, 2001). A análise comparativa do desempenho térmico dos protótipos com base nestes dias típicos assegura que os dados são representativos do verão, sem o risco de analisar-se um dia excepcionalmente quente (a freqüência de ocorrência de 10\% significa que 10\% dos dias de verão apresentam temperaturas máximas superiores ou iguais ao do dia analisado).

Os dias escolhidos durante a exposição apresentaram temperaturas inferiores as citadas na 
Tabela 4.7, onde são apresentados os valores de $\mathrm{TBS}_{\max }$ (temperatura de máxima de bulbo seco) para as freqüências de 10\% correspondentes ao período 1 (Janeiro, Fevereiro e Março) e ao período 2 (Dezembro, Janeiro, Fevereiro e Março) (AKUTSU et al., 2005).

Tabela 4.7: Valores correspondentes ao período 1 e ao período 2 para a freqüência de ocorrência de $10 \%$.

\begin{tabular}{|c|c|c|}
\hline \multirow{2}{*}{ Freqüência de ocorrência } & \multicolumn{2}{|c|}{$\mathrm{TBS}_{\max }$ Verão $\left({ }^{\circ} \mathrm{C}\right)$} \\
\cline { 2 - 3 } & Período 1 & Período 2 \\
\hline $10 \%$ & 31,4 & 31,9 \\
\hline
\end{tabular}

O tempo de exposição foi escolhido de acordo com a variável de radiação global total diária. A exposição natural de cada grupo de tinta foi encerrada com a obtenção de dois dias que apresentassem valores próximos de radiação global total.

Para o cálculo da radiação global total $\left(\mathrm{Wh} / \mathrm{m}^{2}\right)$ foi utilizada uma carta solar da cidade de São Paulo. Através desta carta foram determinados os horários do sol nascente e poente (linha em azul na Figura 4.15).

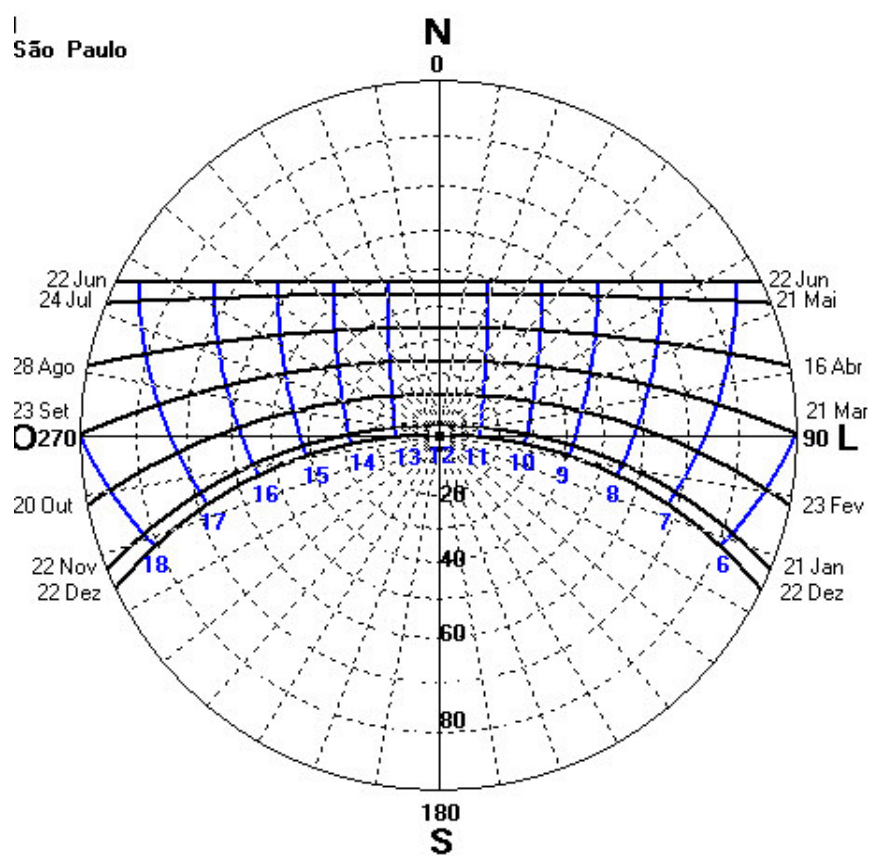

Figura 4.15: Carta solar de São Paulo.

A temperatura foi determinada por meio de termopares tipo $T$, confeccionados com cabos de 
compensação de cobre e constantan. Os termopares foram posicionados da seguinte forma:

- Superfície da cobertura (TS): foram colados na superfície da cobertura dos protótipos. Adotou-se o mesmo critério de pintar o termopar com a tinta da mesma cor da cobertura.

- Face inferior da cobertura (TI): foram colados embaixo da telha de fibrocimento da cobertura.

- Interior do protótipo (TA): foram suspensos no interior do protótipo.

\subsubsection{Condições de exposição}

- Marcação da direção Norte Verdadeiro: os suportes foram montados com a face voltada para o norte geográfico (norte verdadeiro).

- Características dos protótipos: os protótipos foram construídos em placas de madeira tipo MDF de $20 \mathrm{~mm}$ de espessura, com uma área de $0,64 \mathrm{~m}^{2}$ e uma inclinação do telhado de $30^{\circ}$, conforme apresentado na Figura 4.16. Os protótipos foram pintados com 2 demãos de verniz fosco para proteção à ação de intempéries. A inclinação do telhado foi voltada ao equador (face norte para o hemisfério sul). A área de exposição é sem sombreamento e o solo é de concreto (laje).
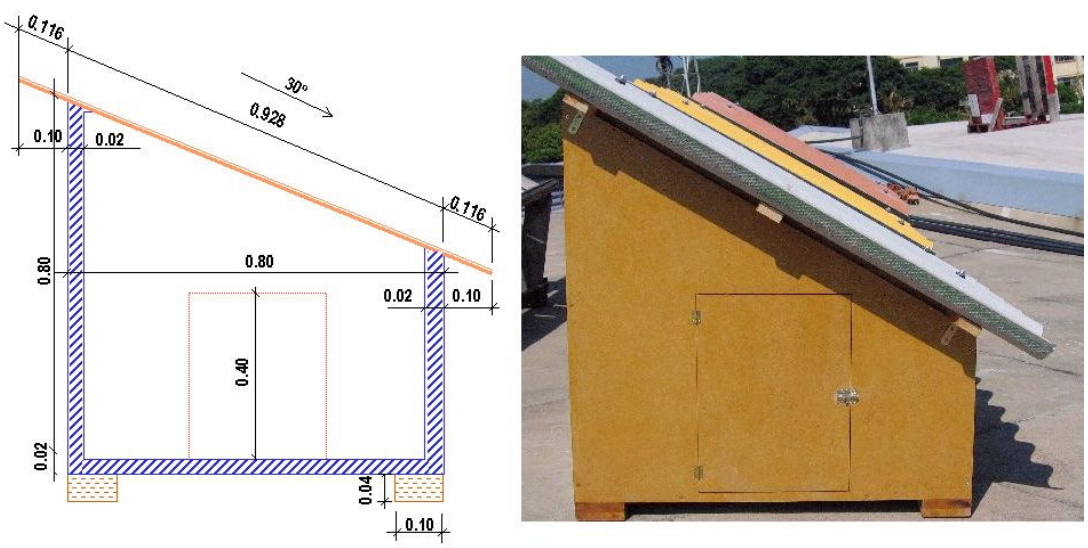

Figura 4.16: Layout e foto do protótipo para exposição natural. 
- Dados meteorológicos: foram fornecidos pelo Laboratório de Micrometeorologia do Instituto Astronômico e Geofísico da Universidade de São Paulo (IAG-USP). A estação está localizada no campus da Cidade Universitária da USP, bairro do Butantã, zona Oeste da Cidade de São Paulo $\left(23.4^{\circ} \mathrm{S}, 46.7^{\circ} \mathrm{W}, 742 \mathrm{~m}\right)$. Todas as observações foram realizadas com freqüência de $0.2 \mathrm{~Hz}$, e armazenadas como valores médios em intervalos de 5 minutos. A monitorização dos dados climáticos é importante para que se obtenha um perfil das variáveis climáticas do ambiente. Os dados climáticos apresentados para esta análise são de:

a) Precipitação $(\mathrm{mm})$ : medida através de um pluviógrafo de Hellmann (marca Lambrecht, vide Figura 4.17)

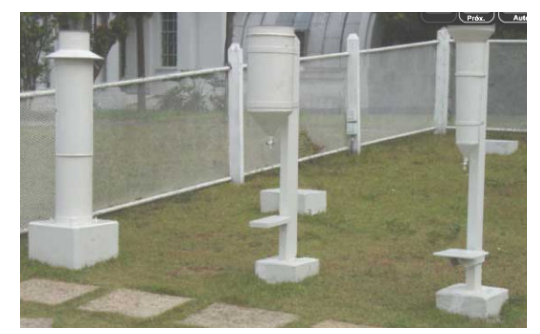

Figura 4.17: Pluviógrafo de Hellmann e pluviômetros Ville de Paris e Paulista.

b) Temperatura do ar $\left({ }^{\circ} \mathrm{C}\right)$ : efetuadas com a leitura do capilar de mercúrio que constitui o bulbo seco de um psicrômetro de aspiração tipo Assmann com motor elétrico (marca Fuess, vide Figura 4.18).

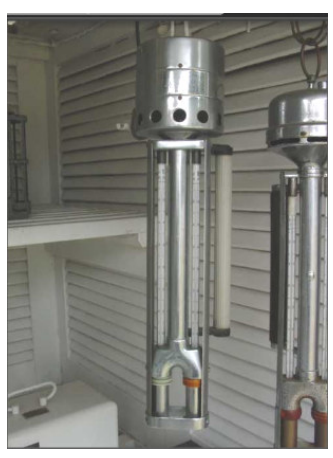

Figura 4.18: Psicrômetro de aspiração tipo Assmann com motor elétrico. 
c) Umidade do ar: medida através da leitura dos capilares de mercúrio que constituem os bulbos seco e úmido de um psicrômetro de aspiração tipo Assmann com motor elétrico (marca Fuess, Figura 4.19).

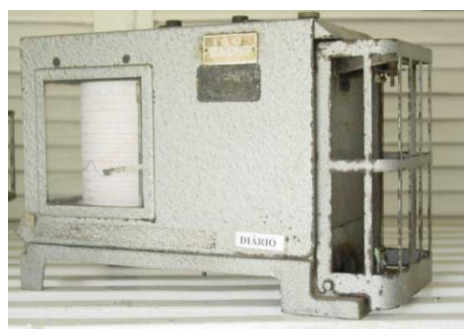

Figura 4.19: Higrógrafo dotado de harpa de fio de cabelo, com rotação diária.

d) Radiação global total: obtida a partir dos registros do actinógrafo bimetálico (marca Fuess, vide Figura 4.20).

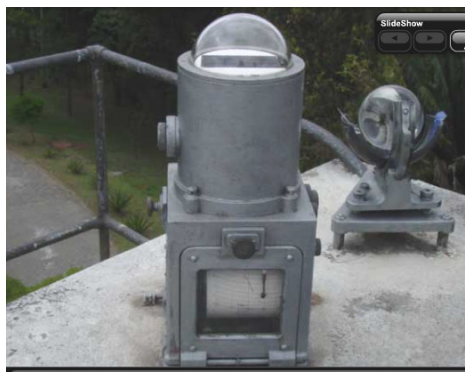

Figura 4.20: Actinógrafo bimetálico instalado no alto da torre da Estação.

\subsubsection{Exposição natural na Estação de Envelhecimento Natural de São Paulo}

Os protótipos foram expostos na Estação do Campus da Universidade de São Paulo, localizada sobre o edifício da Engenharia Civil, junto ao Laboratório de Microestrutura da Escola Politécnica da Universidade de São Paulo - Departamento de Engenharia de Construção Civil (Figura 4.21). A estação tem como coordenadas: latitude 21057'02" S e longitude 47027'50'W, altitude de 630m e declinação magnética de $19^{\circ} 31$ 'W; o meio ambiente está sendo caracterizado pela estação meteorológica instrumentada do IAG - USP. 


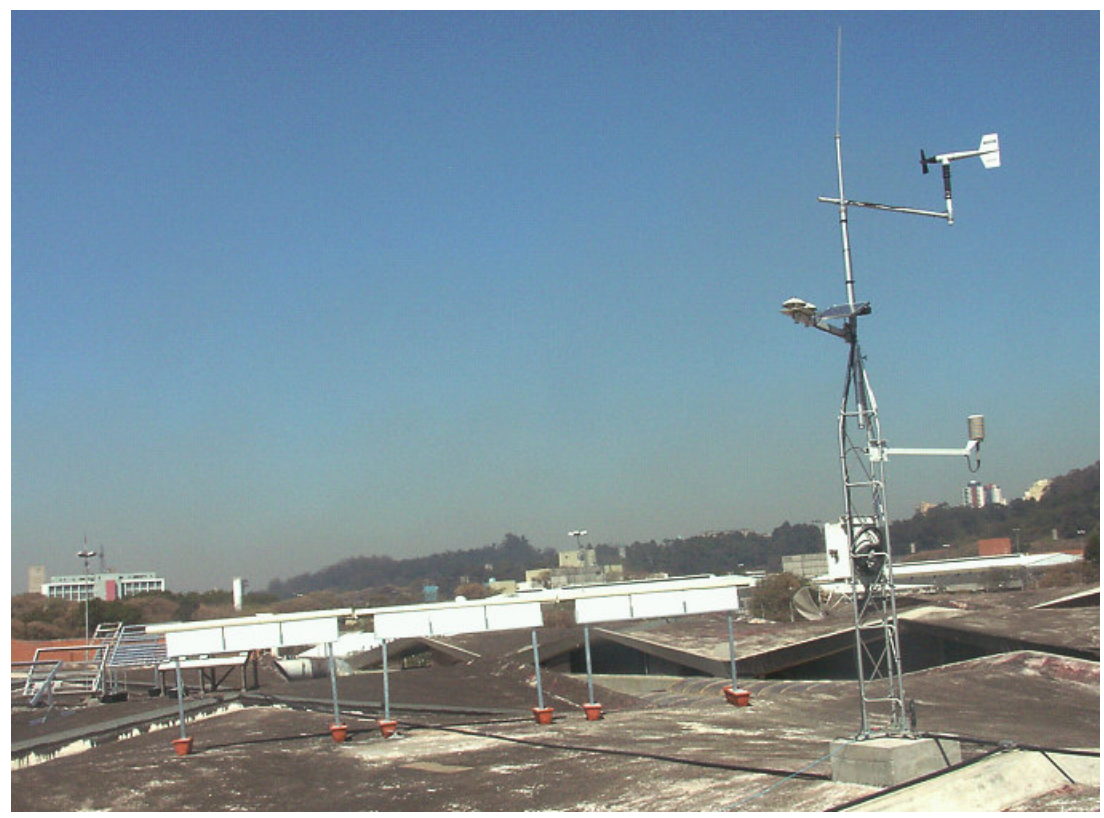

Figura 4.21: Vista da estação de exposição no Departamento de Construção Civil. 
5 Resultados e Discussões

\subsection{Determinação da cor por medida instrumental}

Na Figura 5.1 é apresentada a distribuição de cores no sistema CIE e na Tabela 5.1 estão apresentados os valores de $L^{*}, a^{*} e b^{*}$.
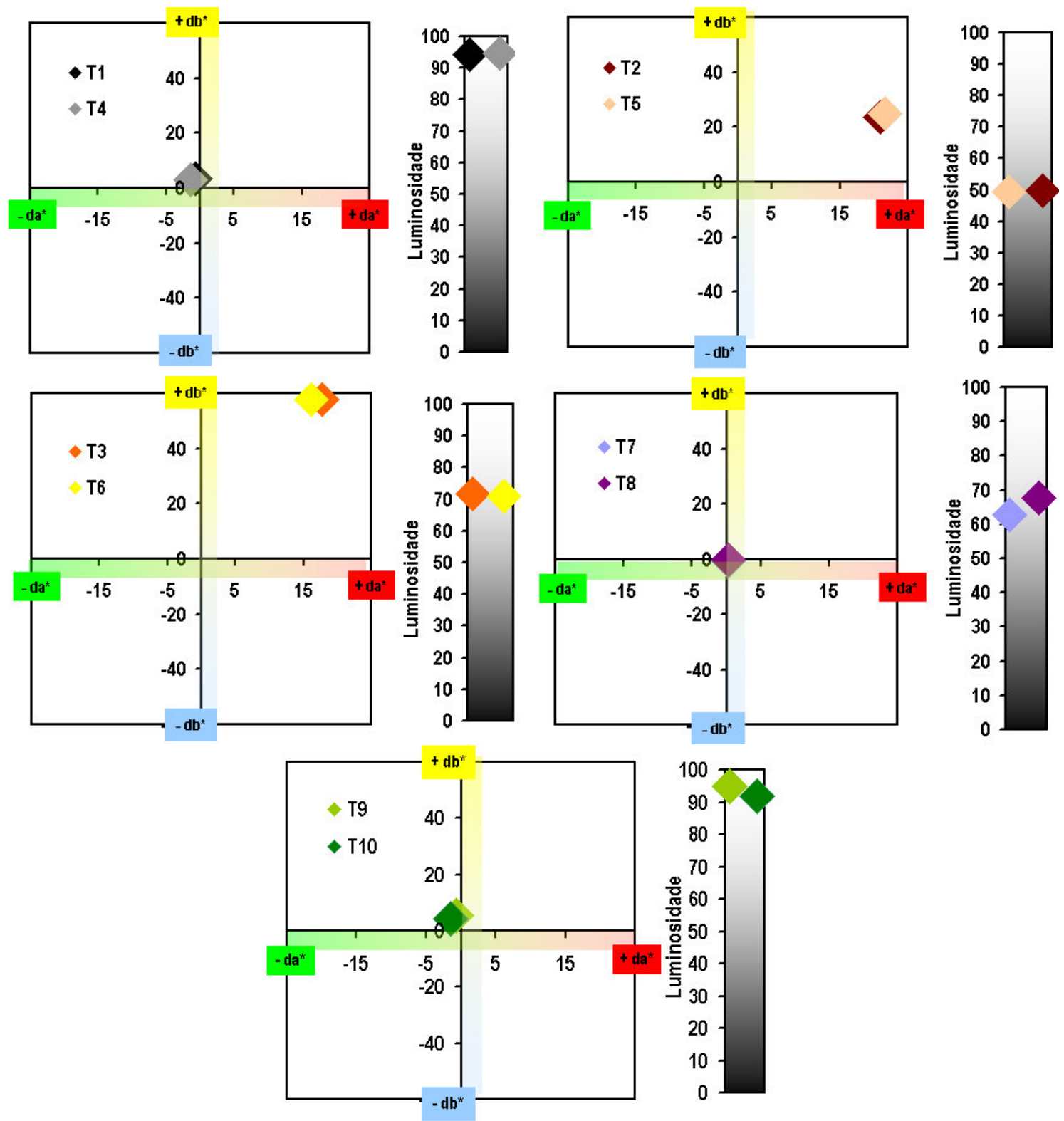

Figura 5.1: Distribuição de cores no Gráfico do CIE L*a*b*. 
Tabela 5.1: Média das leituras de cor das películas de tinta estudadas.

\begin{tabular}{|c|c|c|c|c|c|}
\hline \multirow{2}{*}{ Amostras } & \multirow{2}{*}{ Cor } & \multirow{2}{*}{ Característica } & \multicolumn{3}{|c|}{ média } \\
\cline { 4 - 6 } & & & $\mathrm{L}^{*}$ & $\mathrm{a}^{*}$ & $\mathrm{~b}^{*}$ \\
\hline T1 & Branca & Refletiva & 94,1 & $-0,7$ & 3,4 \\
\hline T2 & Marrom & Refletiva & 49,6 & 20,9 & 23,4 \\
\hline T3 & Amarela & Refletiva & 71,8 & 17,8 & 58,0 \\
\hline T4 & Branca & Convencional & 94,7 & $-1,4$ & 3,2 \\
\hline T5 & Marrom & Convencional & 49,4 & 21,7 & 25,1 \\
\hline T6 & Amarela & Convencional & 70,8 & 16,1 & 57,9 \\
\hline T7 & Alumínio & Refletiva & 62,8 & 0,3 & $-0,5$ \\
\hline T8 & Alumínio & Refletiva & 67,7 & 0,2 & $-0,3$ \\
\hline T9 & Branca & Refletiva & 95,0 & $-0,8$ & 5,4 \\
\hline T10 & Branca & Refletiva & 91,8 & $-1,5$ & 4,2 \\
\hline
\end{tabular}

As tintas de cor branca (T1, T4, T9 e T10) apresentaram valores altos de luminosidade ( $\left.\mathrm{L}^{*}\right) \mathrm{e}$ próximos de 100. Em relação às de tonalidade das cores amarela e verde a T4 e a T10 são um pouco mais esverdeadas que a T1 e a T9.

A análise da cor das tintas de cor marrom (T2 e T5) mostrou valores próximos na escala gráfica, sendo desprezível o pequeno deslocamento observado no eixo $b^{*}$, portanto as tintas T2 e T5 apresentam praticamente, as mesmas cores.

Nas tintas de cor amarela (T3 e T6) observando o eixo $L^{*}$ nota-se que a T3 é mais clara do que a T6. Os valores do b* são positivos e elevados, comprovando ser uma tinta de cor amarela.

A medida das cores das tintas de cor alumínio (T7 e T8) mostra que a T8 é mais luminosa (maior valor no $L^{*}$ ) do que a T7. As tintas de cor alumínio apresentam valores muito próximos, mostrando que ambas as tintas apresentam cores semelhantes.

No geral, todas as tintas do estudo apresentaram correspondência de cores, independente de serem refletivas ou convencionais. 


\subsection{Determinação do brilho}

$\mathrm{Na}$ Tabela 5.2 são apresentados os valores de brilho das películas de tinta, no ângulo de $60^{\circ}$. Valores de PVC fornecidos pelo fabricante foram colocados na tabela para auxiliar a discussão dos resultados.

Tabela 5.2: Resultados de medidas de brilho.

\begin{tabular}{|c|c|c|c|c|}
\hline Amostra & Cor & Característica & Média (UB) & PVC (\%) \\
\hline T1 & Branca & Refletiva & 2,2 & 68 \\
\hline T2 & Marrom & Refletiva & 1,0 & 68 \\
\hline T3 & Amarela & Refletiva & 1,5 & 68 \\
\hline T4 & Branca & Convencional & 4,4 & 30 \\
\hline T5 & Marrom & Convencional & 1,2 & 36 \\
\hline T6 & Amarela & Convencional & 1,8 & 36 \\
\hline T7 & Alumínio & Refletiva & 39,0 & 15 \\
\hline T8 & Alumínio & Refletiva & 18,7 & - \\
\hline T9 & Branca & Refletiva & 2,0 & 81 \\
\hline T10 & Branca & Refletiva & 2,1 & - \\
\hline
\end{tabular}

Os resultados obtidos neste ensaio mostram que as tintas do estudo apresentaram valores de brilho que as classificariam como foscas. Observa-se que as tintas refletivas do estudo T1, T2, T3, T9 e T10 apresentaram valores elevados de PVC e podem ser classificadas como tintas foscas. Já as tintas convencionais T4, T5 e T6 apresentaram valores de PVC em torno de 33\%, e podem ser classificadas como tintas acetinadas. $E$ as tintas refletivas de cor alumínio (T7 e T8) podem ser classificadas como semibrilho ou alto brilho.

Os resultados de brilho puderam ser correlacionados com a literatura apresentada no Capítulo 3 , sobre a influência do PVC no brilho das tintas.

\subsection{Determinação da refletância por espectrofotometria}

\subsubsection{Películas de tinta e telha de fibrocimento}

Na Figura 5.2 são apresentados os espectros de refletância de todas as películas das tintas estudadas e na Figura 5.3 é apresentado o espectro da telha de fibrocimento, isoladamente. 
Na Tabela 5.3 são apresentados os valores médios de refletância de todas as películas tintas estudadas. A refletância dos materiais representa a porcentagem de energia refletida, conseqüentemente o restante é absorvido pelo material.

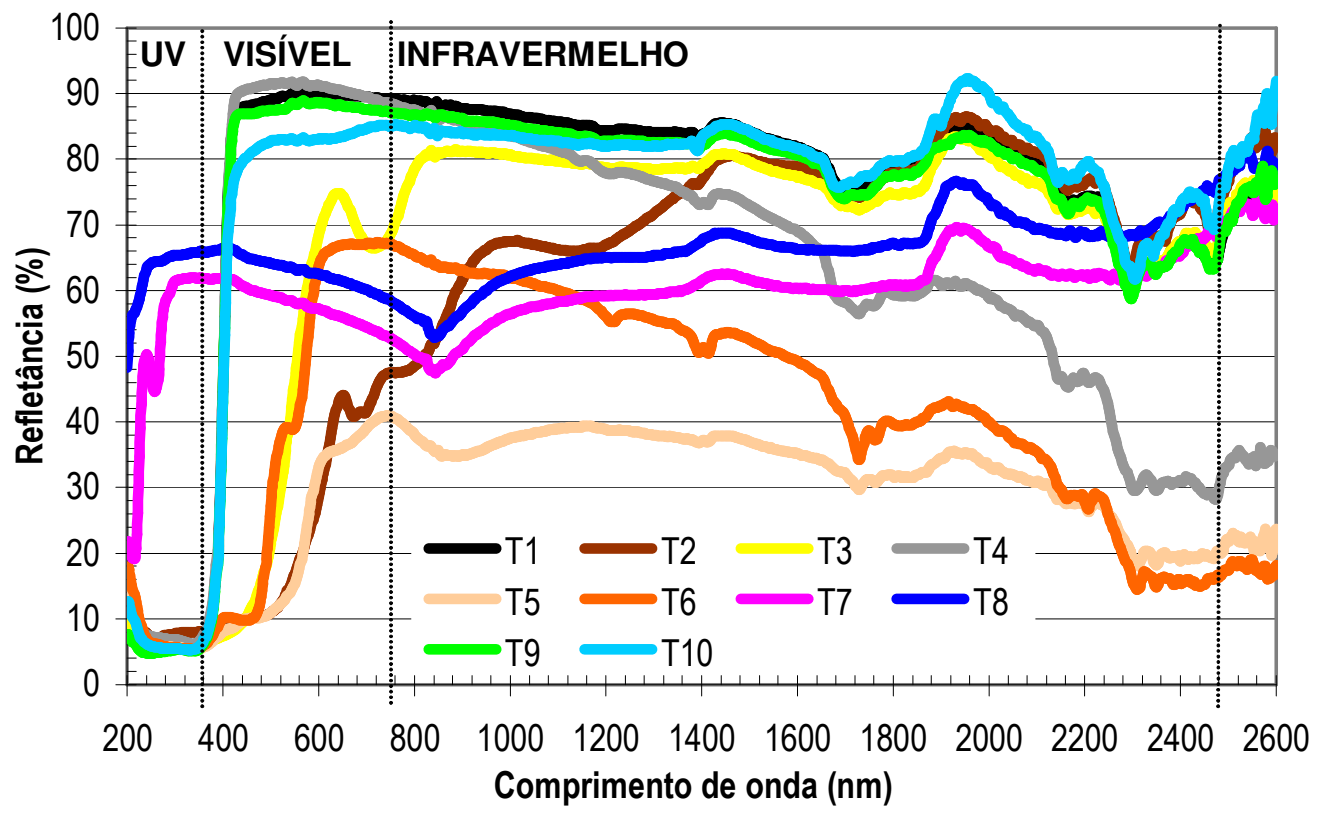

Figura 5.2: Espectro de todas as películas de tintas estudadas.

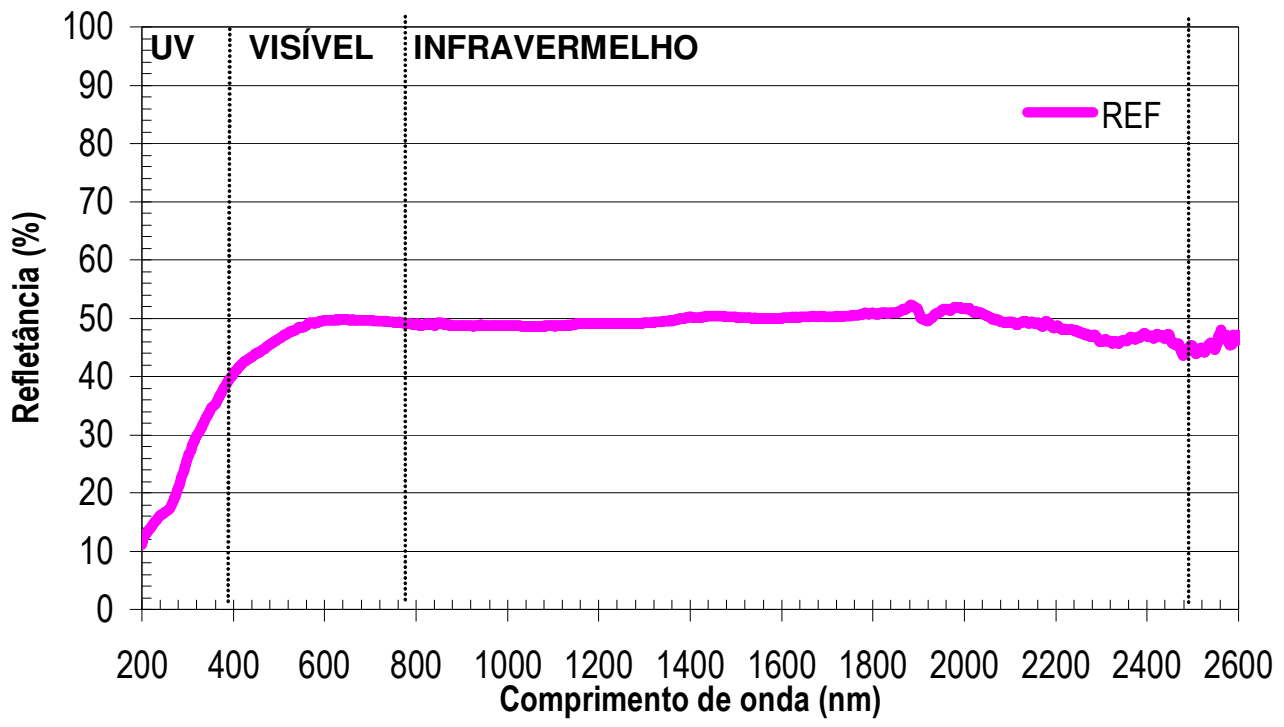

Figura 5.3: Espectro da telha de fibrocimento. 
Tabela 5.3: Resultados médios de refletância das películas de todas as tintas estudadas.

\begin{tabular}{|c|c|c|c|c|c|}
\hline \multirow{2}{*}{ Amostras } & \multirow{2}{*}{ Cor } & \multicolumn{4}{|c|}{$\mathrm{R}(\%)$} \\
\cline { 3 - 6 } & & UV & VI & IV & TOTAL \\
\hline REF & - & 23.5 & 46.3 & 48.2 & 45.9 \\
\hline T1 & Branca & 6.5 & 84.9 & 80.1 & 77.9 \\
\hline T2 & Marrom & 8.0 & 26.4 & 72.9 & 61.9 \\
\hline T3 & Amarela & 5.8 & 46.3 & 76.2 & 67.9 \\
\hline T4 & Branca & 7.3 & 86.0 & 63.8 & 65.5 \\
\hline T5 & Marrom & 5.7 & 24.4 & 32.8 & 30.2 \\
\hline T6 & Amarela & 5.8 & 44.4 & 44.4 & 42.8 \\
\hline T7 & \multirow{2}{*}{ Alumínio } & 61.7 & 57.4 & 60.6 & 60.1 \\
\cline { 3 - 6 } & 65.7 & 62.6 & 66.8 & 66.0 \\
\hline T8 & & 8.6 & 83.3 & 74.9 & 73.7 \\
\hline T9 & \multirow{2}{*}{ Branca } & 6.2 & 78.3 & 79.5 & 76.3 \\
\hline T10 & & & &
\end{tabular}

Na distribuição dos valores de refletância no espectro solar apresentados observa-se que:

- Região UV (ultravioleta): a baixa refletância nesta região do espectro solar, causa alteração de cor da superfície (descoloração) e do brilho.

- Região VI (visível): observou-se que quanto mais clara a superfície, maior é o seu valor de refletância para as tintas convencionais e refletivas.

- Região IV (infravermelho): os resultados mostraram que os materiais caracterizados como refletivos apresentaram um valor de refletância superior às tintas convencionais.

Os resultados mostram que a telha de fibrocimento apresenta uma refletância total significativa. Outros fatores como a rugosidade da superfície da telha e a exposição às variáveis climáticas interferem na sua refletância. Além da telha de fibrocimento apresentar irregularidades na sua superfície envolvendo uma escala de milímetros e de centímetros, chamadas de ondulação. № entanto, Roriz, Dornelles, e Roriz (2007) constataram que o perfil da telha não interfere sobre a quantidade total de radiação direta que incide sobre a cobertura, pois a ondulação aumenta tanto a área da superfície quanto as áreas sombreadas e os ângulos de incidência, sendo nula a conjugação desses efeitos. 


\subsubsection{Tinta de cor branca}

\subsubsection{Película de cor branca}

Na Figura 5.4 são apresentados os espectros de refletância das películas das tintas de cor branca refletiva (T1) e convencional (T4) e na Tabela 5.4 são apresentados os valores médios de refletância.

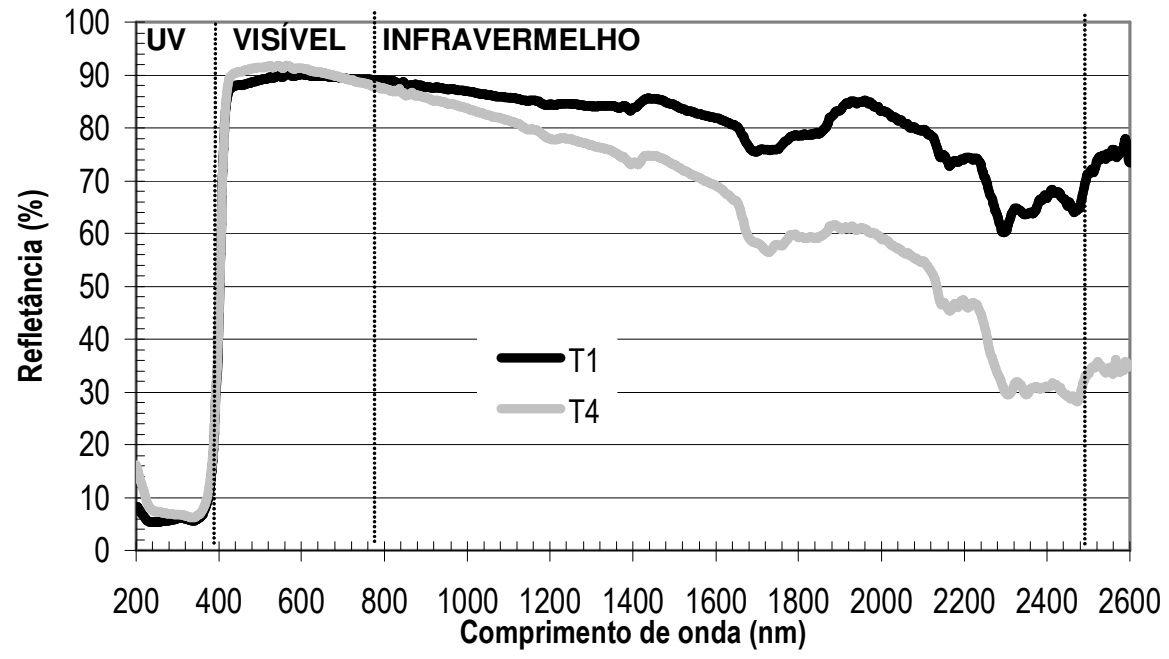

Figura 5.4: Espectro das tintas de cor branca (T1 e T4).

Tabela 5.4: Resultados médios de refletância das películas das tintas de cor branca.

\begin{tabular}{|c|c|c|c|c|}
\hline \multirow{2}{*}{ Amostras } & \multicolumn{4}{|c|}{$\mathrm{R}(\%)$} \\
\cline { 2 - 5 } & $\mathrm{UV}$ & $\mathrm{VI}$ & $\mathrm{IV}$ & $\mathrm{TOTAL}$ \\
\hline $\mathrm{T} 1$ & 6.5 & 84.9 & 80.1 & 77.9 \\
\hline $\mathrm{T} 4$ & 7.3 & 86.0 & 63.8 & 65.5 \\
\hline
\end{tabular}

Ambas as tintas brancas estudadas apresentaram uma elevada refletância na região do visivel; mas justamente na região do infravermelho, a película de tinta acrílica convencional (T4) apresentou menor refletância em relação à película refletiva (T1). A película refletiva de cor branca (T1) apresenta um alto valor de refletância na região do visivel e do infravermelho.

\subsubsection{Telha de fibrocimento com pintura branca}

Na Figura 5.5 são apresentados os espectros de refletância da telha de fibrocimento (REF) e das telhas de fibrocimento com pintura branca refletiva (REF + T1) e convencional $(R E F+T 4)$ e na 
Tabela 5.5 são apresentados os valores médios de refletância.

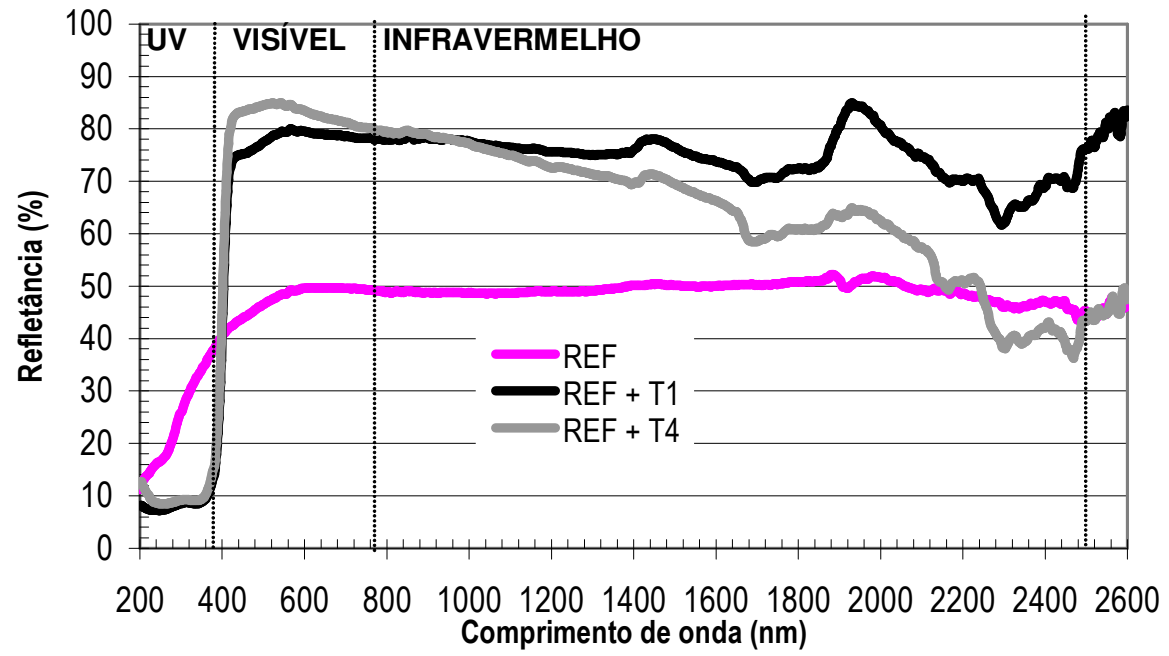

Figura 5.5: Espectro comparativo da T1 (refletiva branca) e da T4 (tinta convencional) aplicadas na REF (telha de fibrocimento).

Tabela 5.5: Resultados médios de refletância das tintas de cor branca aplicadas na telha de fibrocimento.

\begin{tabular}{|c|c|c|c|c|}
\hline \multirow{2}{*}{ Amostras } & \multicolumn{4}{|c|}{$\mathrm{R}(\%)$} \\
\cline { 2 - 5 } & UV & $\mathrm{VI}$ & $\mathrm{IV}$ & TOTAL \\
\hline REF & 23,5 & 46,3 & 48,2 & 45,9 \\
\hline REF + T1 & 8,2 & 72,8 & 73,0 & 67,9 \\
\hline REF + T4 & 9,4 & 77,3 & 62,2 & 60,7 \\
\hline
\end{tabular}

A aplicação das tintas brancas na telha de fibrocimento melhorou significativamente a refletância da telha de fibrocimento $(R E F)$. A tinta refletiva $(R E F+T 1)$ apresentou valores mais elevados de refletância, principalmente na região do infravermelho, quando comparada com a tinta convencional branca (REF + T4).

\subsubsection{Tinta de cor marrom}

\subsubsection{Película de cor marrom}

Na Figura 5.6 são apresentados os espectros de refletância das películas das tintas de cor marrom refletiva (T2) e convencional (T5) e na Tabela 5.6 são apresentados os valores médios de refletância. 


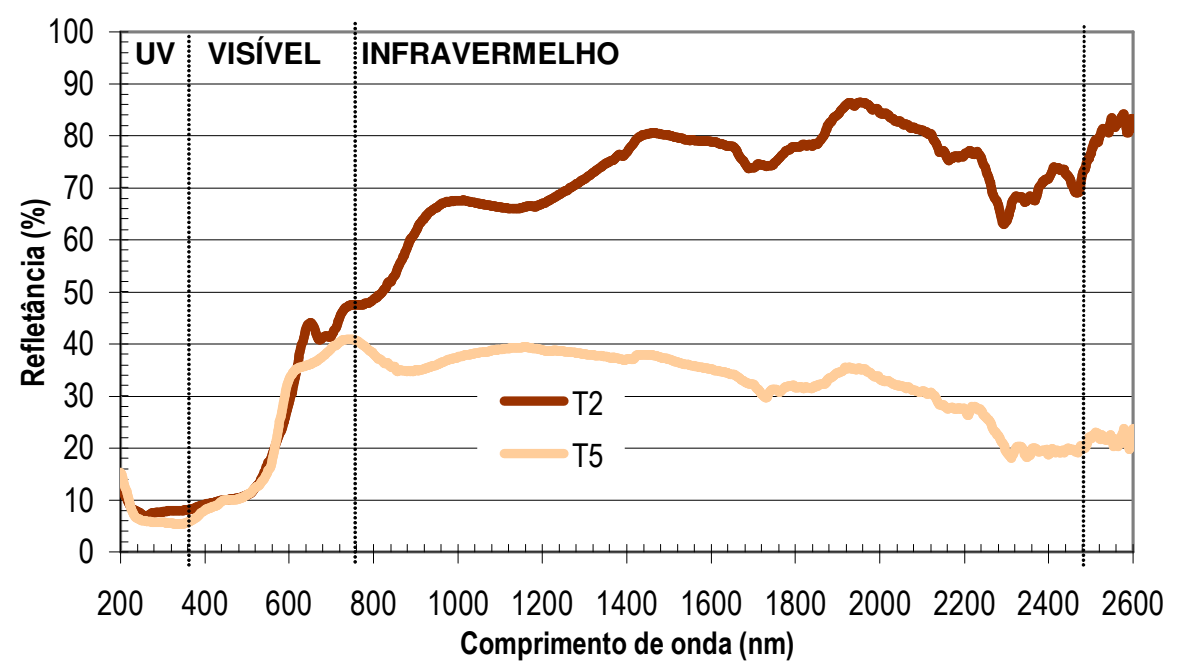

Figura 5.6: Espectro das tintas de cor marrom (T2 e T5).

Tabela 5.6: Resultados médios de refletância das películas das tintas de cor marrom.

\begin{tabular}{|c|c|c|c|c|}
\hline \multirow{2}{*}{ Amostras } & \multicolumn{4}{|c|}{$\mathrm{R}(\%)$} \\
\cline { 2 - 5 } & UV & VI & IV & TOTAL \\
\hline T2 & 8.0 & 26.4 & 72.9 & 61.9 \\
\hline T5 & 5.7 & 24.4 & 32.8 & 30.2 \\
\hline
\end{tabular}

A película refletiva de cor marrom (T2) apresenta um alto valor de refletância na região do infravermelho, o que melhora o desempenho térmico da sua superfície, quando comparada com a T5 (convencional). As curvas na região do UV e do visível são características de cores escuras mostrando um baixo valor de refletância nestas regiões.

\subsubsection{Telha de fibrocimento com pintura marrom}

Na Figura 5.7 são apresentados os espectros de refletância da telha de fibrocimento (REF) e das telhas de fibrocimento com pintura marrom refletiva $(R E F+T 2)$ e convencional $(R E F+T 5)$ e na Tabela 5.7 são apresentados os valores médios de refletância. 


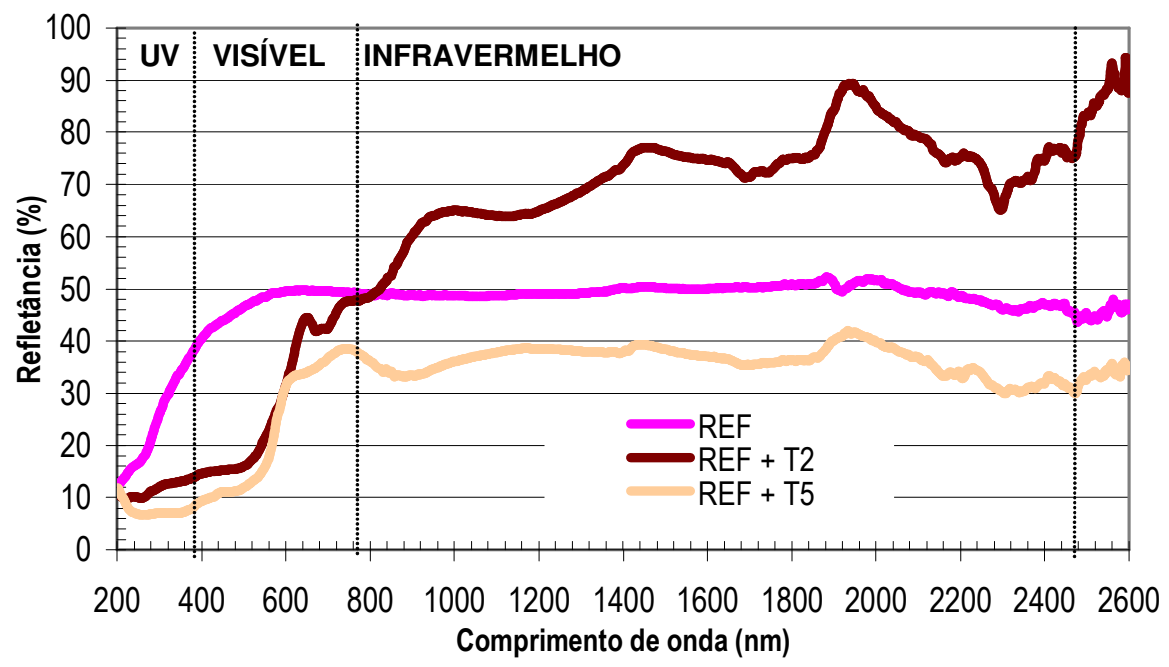

Figura 5.7: Espectro comparativo da T2 (refletiva marrom) e da T5 (convencional marrom) aplicadas na REF (telha de fibrocimento).

Tabela 5.7: Resultados médios de refletância das tintas de cor marrom aplicadas na telha de fibrocimento.

\begin{tabular}{|c|c|c|c|c|}
\hline \multirow{2}{*}{ Amostras } & \multicolumn{4}{|c|}{$\mathrm{R}(\%)$} \\
\cline { 2 - 5 } & UV & VI & IV & TOTAL \\
\hline REF & 23,5 & 46,3 & 48,2 & 45,9 \\
\hline REF + T2 & 11,3 & 28,8 & 70,4 & 58,5 \\
\hline REF + T5 & 7,4 & 23,3 & 35,5 & 31,2 \\
\hline
\end{tabular}

Os resultados mostram que a tinta refletiva marrom (REF+T2) quando aplicada na telha de fibrocimento (REF) melhorou a refletância da telha, principalmente na região do infravermelho. Em compensação, observa-se que a tinta convencional marrom (REF + T5) diminuiu a refletância da telha de fibrocimento (REF).

\subsubsection{Tinta de cor amarela}

\subsubsection{Película de cor amarela}

Na Figura 5.8 são apresentados os espectros de refletância das películas das tintas de cor amarela refletiva (T3) e convencional (T6) e na Tabela 5.8 são apresentados os valores médios de refletância. 


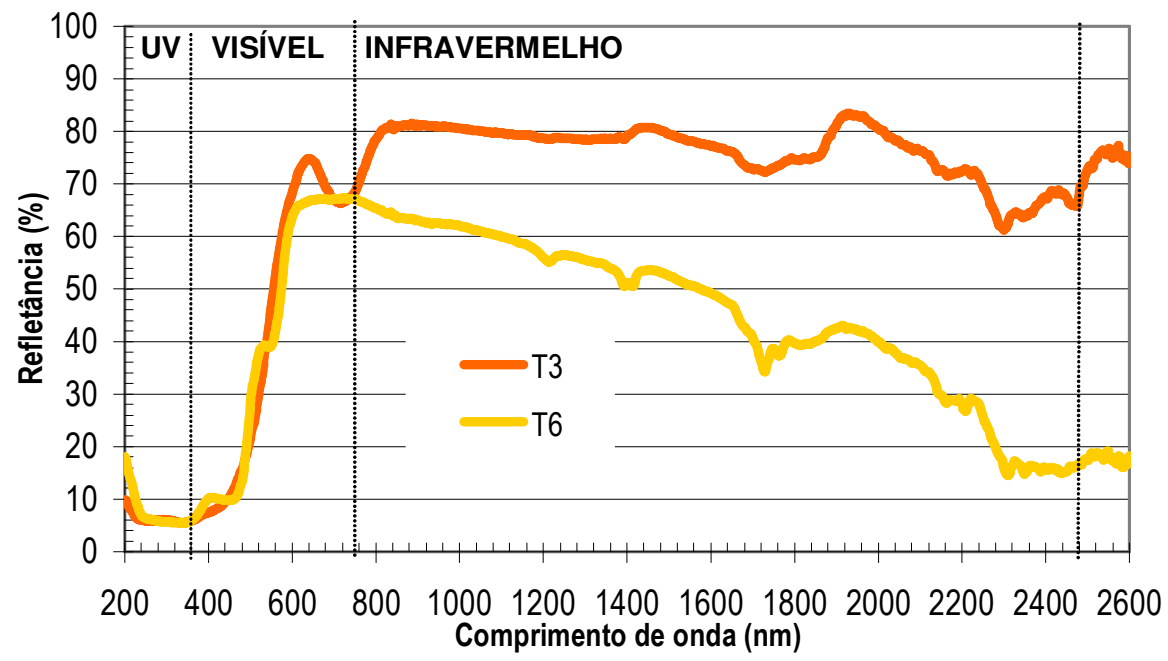

Figura 5.8: Espectro das tintas de cor amarela (T3 e T6).

Tabela 5.8: Resultados médios de refletância das películas das tintas de cor amarela.

\begin{tabular}{|c|c|c|c|c|}
\hline \multirow{2}{*}{ Amostras } & \multicolumn{4}{|c|}{$\mathrm{R}(\%)$} \\
\cline { 2 - 5 } & UV & VI & IV & TOTAL \\
\hline T3 & 5,8 & 46,3 & 76,2 & 67,9 \\
\hline T6 & 5,8 & 44,4 & 44,4 & 42,8 \\
\hline
\end{tabular}

As tintas de cor amarela apresentaram curvas semelhantes no UV e no visivel. Os espectros tornaram-se distintos na região do infravermelho. A película amarela refletiva (T3) quando comparada com a película amarela convencional (T6) apresenta um valor superior de refletância na região do infravermelho.

\subsubsection{Telha de fibrocimento com pintura amarela}

Na Figura 5.9 são apresentados os espectros de refletância da telha de fibrocimento (REF) e das telhas de fibrocimento com pintura amarela refletiva (REF + T3) e convencional (REF + T6) e na Tabela 5.9 são apresentados os valores médios de refletância 


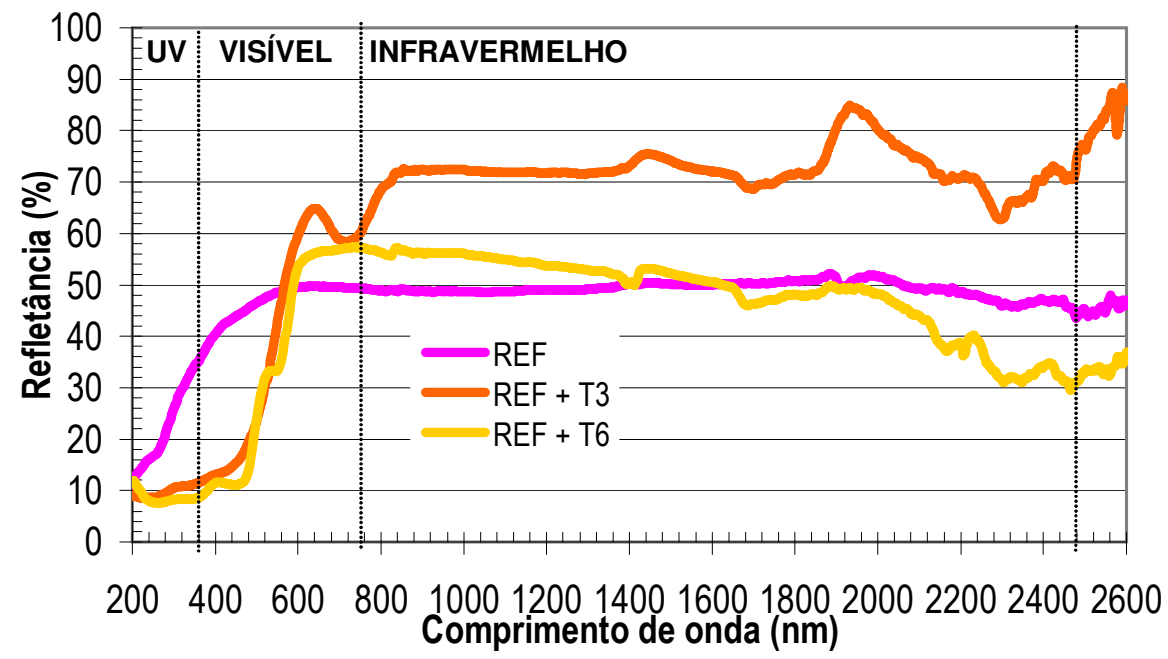

Figura 5.9: Espectro comparativo da T3 (refletiva amarela) e da T6 (convencional amarela) aplicadas na REF (telha de fibrocimento).

Tabela 5.9 Resultados médios de refletância das tintas de cor amarela aplicadas na telha de fibrocimento.

\begin{tabular}{|c|c|c|c|c|}
\hline \multirow{2}{*}{ Amostras } & \multicolumn{4}{|c|}{$\mathrm{R}(\%)$} \\
\cline { 2 - 5 } & UV & VI & IV & TOTAL \\
\hline REF & 23,5 & 46,3 & 48,2 & 45,9 \\
\hline REF + T3 & 9,9 & 42,5 & 72,1 & 62,1 \\
\hline REF + T6 & 8,4 & 37,6 & 46,9 & 42,3 \\
\hline
\end{tabular}

Observa-se que a tinta refletiva amarela $(\mathrm{REF}+\mathrm{T} 3)$ melhorou significativamente a refletância da telha de fibrocimento (REF), principalmente na região do infravermelho. Já a tinta convencional amarela (REF + T6) apesar de ser uma tinta de cor clara, não melhorou a refletância da telha de fibrocimento (REF).

\subsubsection{Tinta de cor alumínio}

\subsubsection{Película de cor alumínio}

Na Figura 5.10 são apresentados os espectros de refletância das películas das tintas de cor alumínio refletiva nacional (T7) e internacional (T8) e na Tabela 5.10 são apresentados os valores médios de refletância. 


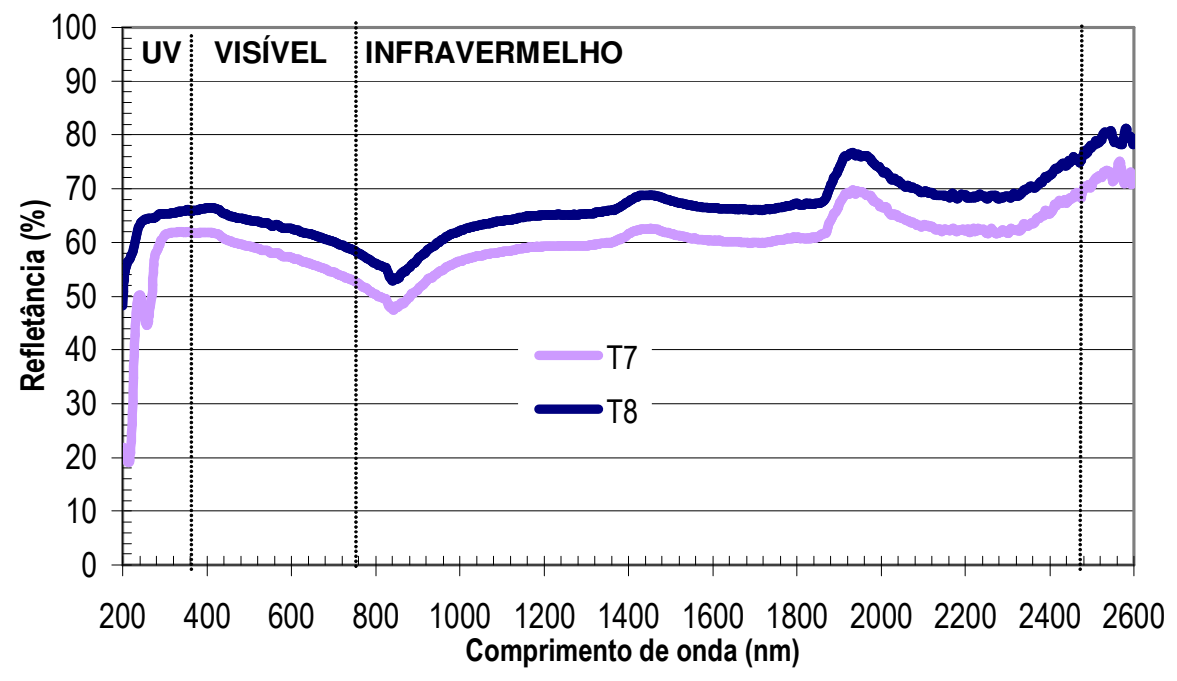

Figura 5.10: Espectro das tintas de cor alumínio (T7 e T8).

Tabela 5.10: Resultados médios de refletância das películas das tintas de cor alumínio.

\begin{tabular}{|c|c|c|c|c|}
\hline \multirow{2}{*}{ Amostras } & \multicolumn{4}{|c|}{$\mathrm{R}(\%)$} \\
\cline { 2 - 5 } & $\mathrm{UV}$ & $\mathrm{VI}$ & $\mathrm{IV}$ & TOTAL \\
\hline T7 & 61,7 & 57,4 & 60,6 & 60,1 \\
\hline T8 & 65,7 & 62,6 & 66,8 & 66,0 \\
\hline
\end{tabular}

As películas refletivas de cor alumínio (T7 e T8) apresentaram curvas de refletância muito características. O valor de refletância na região UV mostra que as tintas de cor alumínio, apresentariam uma maior proteção ao substrato. Em relação a refletância na região do visível e do infravermelho, a película refletiva de cor alumínio internacional (T8) apresenta valores um pouco superiores em ambas regiões em relação a película refletiva de cor alumínio nacional (T7).

\subsubsection{Telha de fibrocimento com pintura refletiva alumínio}

Na Figura 5.11 são apresentados os espectros de refletância da telha de fibrocimento (REF) e das telhas de fibrocimento com pintura alumínio refletiva nacional $(R E F+T 7)$ e internacional (REF + T8) e na Tabela 5.11 são apresentados os valores médios de refletância. 


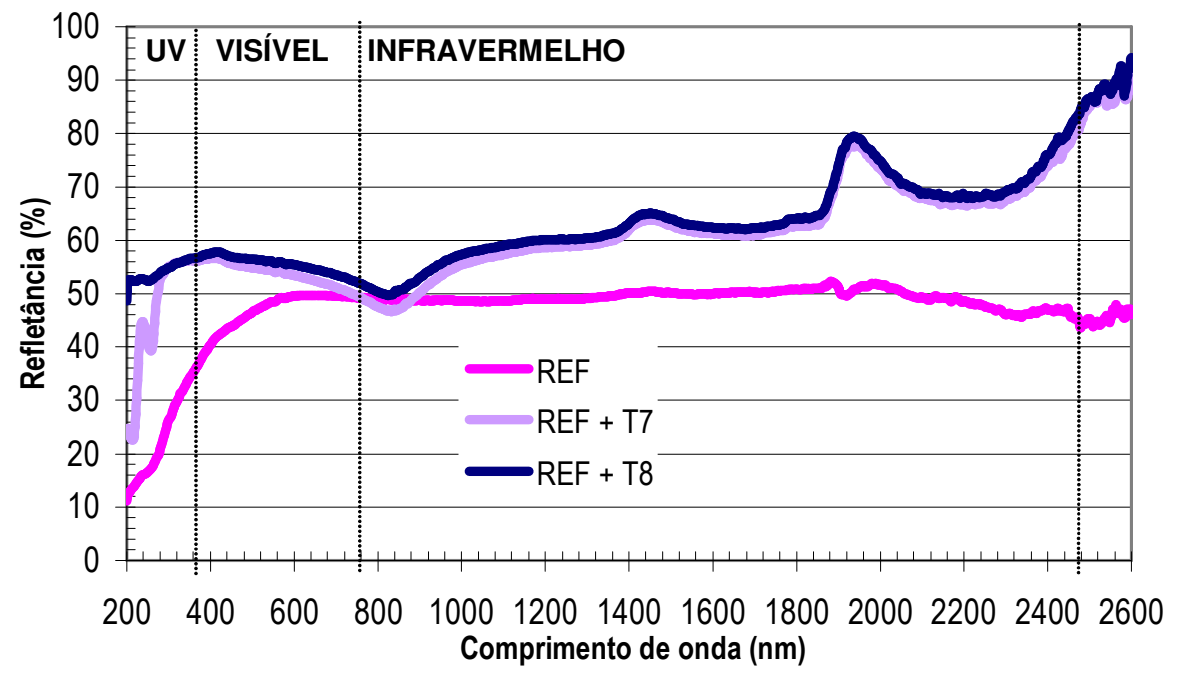

Figura 5.11: Espectro comparativo da T7 (refletiva alumínio nacional) e da T8 (refletiva alumínio internacional) aplicadas na REF (telha de fibrocimento).

Tabela 5.11: Resultados médios de refletância das tintas de cor alumínio aplicadas na telha de fibrocimento.

\begin{tabular}{|c|c|c|c|c|}
\hline \multirow{2}{*}{ Amostras } & \multicolumn{4}{|c|}{$\mathrm{R}(\%)$} \\
\cline { 2 - 5 } & UV & VI & IV & TOTAL \\
\hline REF & 23,5 & 46,3 & 48,2 & 45,9 \\
\hline REF + T7 & 42,7 & 42,7 & 65,6 & 59,8 \\
\hline REF + T8 & 53,1 & 54,1 & 63,4 & 61,0 \\
\hline
\end{tabular}

A aplicação das tintas de cor alumínio refletivas (REF + T7 e REF + T8) nas telhas de fibrocimento (REF) melhorou a refletância da telha de fibrocimento. Ambas as tintas apresentaram valores de refletância próximos na região do infravermelho, mas superiores em relação a cobertura de telha de fibrocimento sem pintura (REF).

\subsubsection{Tinta refletiva de cor branca com cargas especiais}

\subsubsection{Película de cor branca}

Na Figura 5.12 são apresentados os espectros de refletância das películas das tintas de cor branca refletivas com microesferas de vidro (T9) e microesferas cerâmicas (T10) e na Tabela 5.12 são apresentados os valores médios de refletância. 


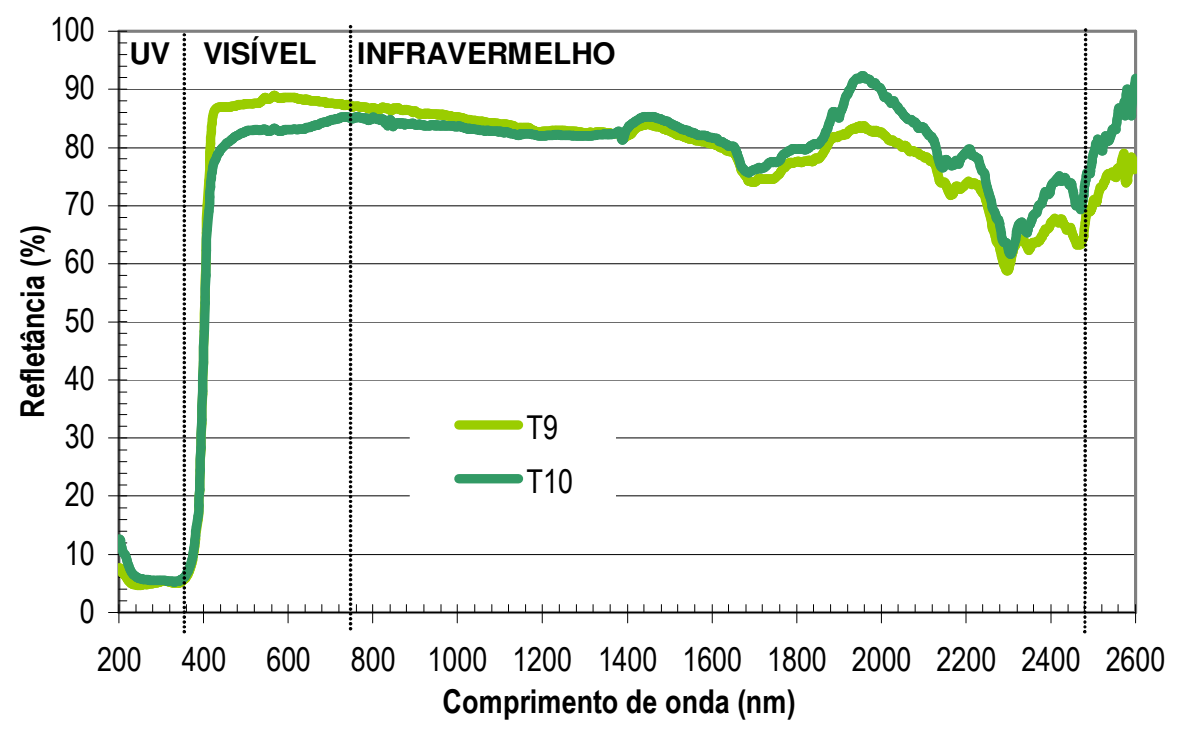

Figura 5.12: Espectro das tintas de cor branca (T9 e T10).

Tabela 5.12: Média das leituras de refletância das películas das tintas de cor branca (com adição de cargas especiais).

\begin{tabular}{|c|c|c|c|c|}
\hline \multirow{2}{*}{ Amostras } & \multicolumn{4}{|c|}{$\mathrm{R}(\%)$} \\
\cline { 2 - 5 } & UV & $\mathrm{VI}$ & $\mathrm{IV}$ & TOTAL \\
\hline T9 & 8,6 & 83,3 & 74,9 & 73,7 \\
\hline T10 & 6,2 & 78,3 & 79,5 & 76,3 \\
\hline
\end{tabular}

Ambas as tintas brancas estudadas, T9 e T10 apresentaram uma elevada refletância na região do visível e na região do infravermelho, mostrando uma eficiência térmica que não é observada na T4 (convencional). Praticamente não foi observada nenhuma diferença na refletância das tintas T9 e T10, independente do tipo de carga adicionada na sua formulação.

\subsubsection{Telha de fibrocimento com pintura branca refletiva}

Na Figura 5.13 são apresentados os espectros de refletância da telha de fibrocimento (REF) e das telhas de fibrocimento com pintura branca refletiva com microesferas de vidro $(R E F+T 9)$ e microesferas cerâmicas (REF + T10) e na Tabela 5.13 são apresentados os valores médios de refletância. 


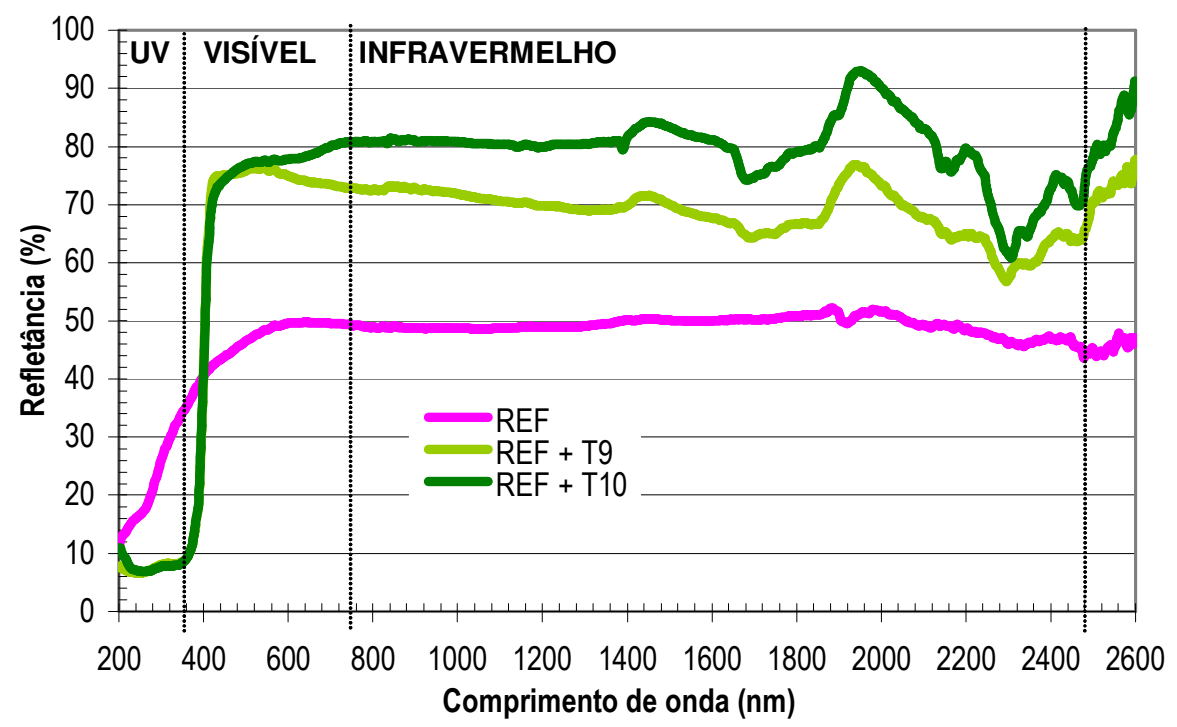

Figura 5.13: Espectro comparativo da T9 (refletiva branca com esferas de vidro ocas) e da T10 (refletiva branca com microesferas cerâmicas) aplicadas na REF (telha de fibrocimento).

Tabela 5.13: Média das leituras de refletância das tintas refletivas de cor branca aplicadas na telha de fibrocimento.

\begin{tabular}{|c|c|c|c|c|}
\hline \multirow{2}{*}{ Amostras } & \multicolumn{4}{|c|}{$\mathrm{R}(\%)$} \\
\cline { 2 - 5 } & UV & VI & IV & TOTAL \\
\hline REF & 23,5 & 46,3 & 48,2 & 45,9 \\
\hline REF + T9 & 7,7 & 69,7 & 67,1 & 62,9 \\
\hline REF + T10 & 8,0 & 72,5 & 78,0 & 71,6 \\
\hline
\end{tabular}

Ambas as tintas refletivas brancas com cargas especiais (REF + T9 e REF $+T 10)$ melhoraram a refletância da telha de fibrocimento (REF) na região do infravermelho. 0 tipo de carga e os teores adicionados podem ter influenciado nos valores de refletância obtidos. Isto só poderá ser verificado através de uma análise química mais detalhada.

\subsection{Efeito da radiação infravermelha na temperatura dos corpos-de-prova}

\subsubsection{Tinta de cor branca}

A Figura 5.14 apresenta os resultados de medida de temperatura das tintas de cor branca e a Tabela 5.14 apresenta as temperaturas máximas e a média das temperaturas medidas pelos termopares. 

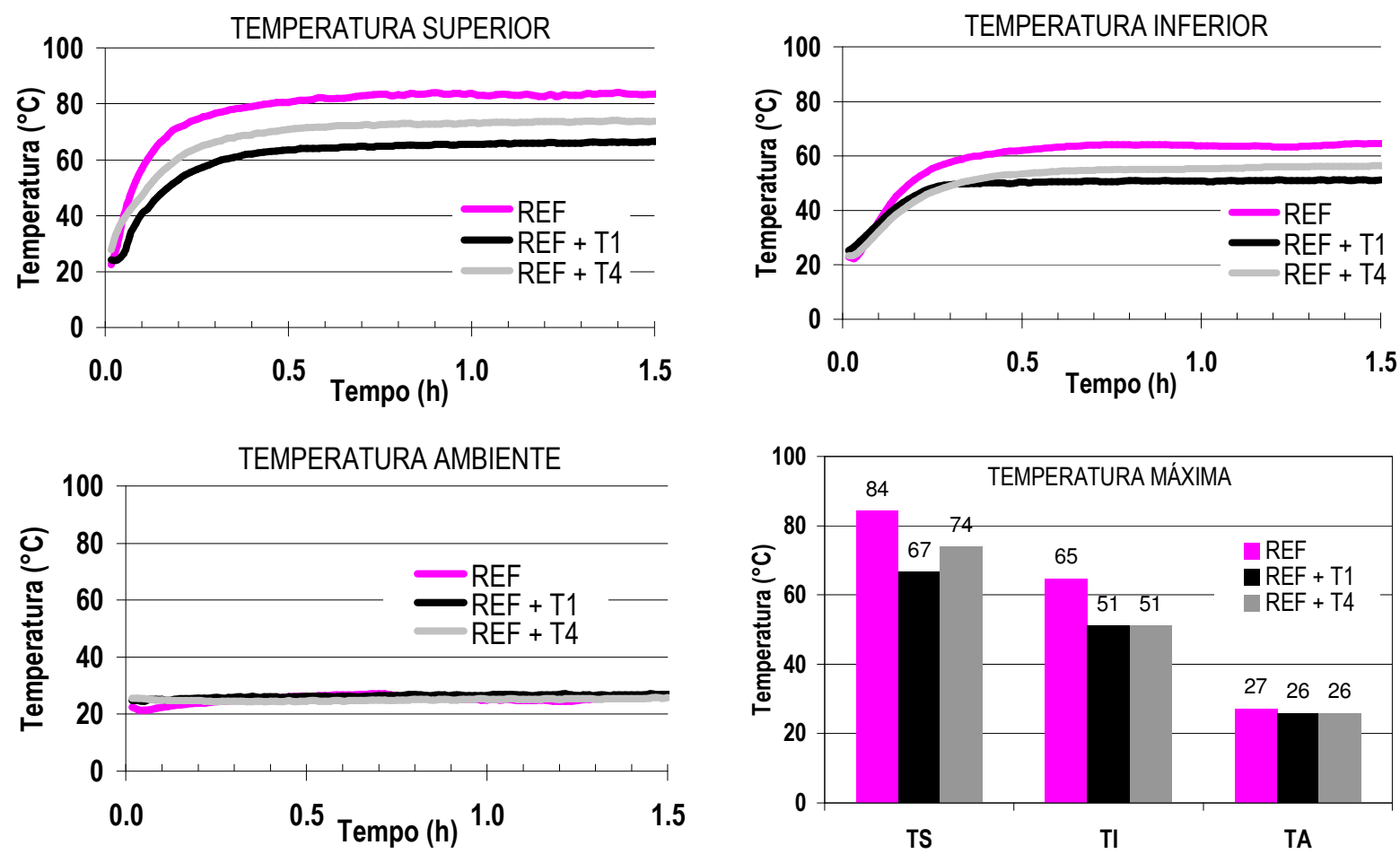

Figura 5.14: Gráfico de temperaturas da tinta branca refletiva (REF + T1) e convencional (REF + T4) aplicadas na telha de fibrocimento (REF).

Tabela 5.14: Temperaturas máximas e médias das tintas de cor branca.

\begin{tabular}{|c|c|c|c|c|c|c|c|}
\hline \multirow{2}{*}{ Amostra } & \multirow{2}{*}{ Cor - característica } & \multicolumn{3}{|c|}{ Temp. Máx. $\left({ }^{\circ} \mathrm{C}\right)$} & \multicolumn{3}{c|}{ Temp. Média $\left({ }^{\circ} \mathrm{C}\right)$} \\
\cline { 3 - 8 } & & TS & TI & TA & TS & TI & TA \\
\hline REF & telha fibrocimento & 84,2 & 64,7 & 27,3 & 78,4 & 59,4 & 25,4 \\
\hline T1 & branca refletiva & 66,7 & 51,2 & 25,9 & 61,1 & 48,5 & 25,0 \\
\hline T4 & branca convencional & 74,0 & 57,0 & 27,1 & 68,5 & 52,3 & 26,3 \\
\hline
\end{tabular}

Os resultados mostram que ambas as tintas de cor branca $(\mathrm{REF}+\mathrm{T} 1 \mathrm{E} \mathrm{REF}+\mathrm{T} 4)$ melhoraram 0 desempenho térmico da telha de fibrocimento (REF) diminuindo a sua temperatura superficial (TS) e a temperatura interna (TI). As temperaturas no interior do equipamento (TA) se mantiveram próximas indicando que o calor absorvido pela telha de fibrocimento era somente por irradiação e não por convecção devido ao aquecimento no interior do equipamento.

\subsubsection{Tinta de cor marrom}

A Figura 5.15 apresentam os resultados de medida de temperatura das tintas de cor marrom e a Tabela 5.15 apresenta as temperaturas máximas e a média das temperaturas medidas pelos termopares. 

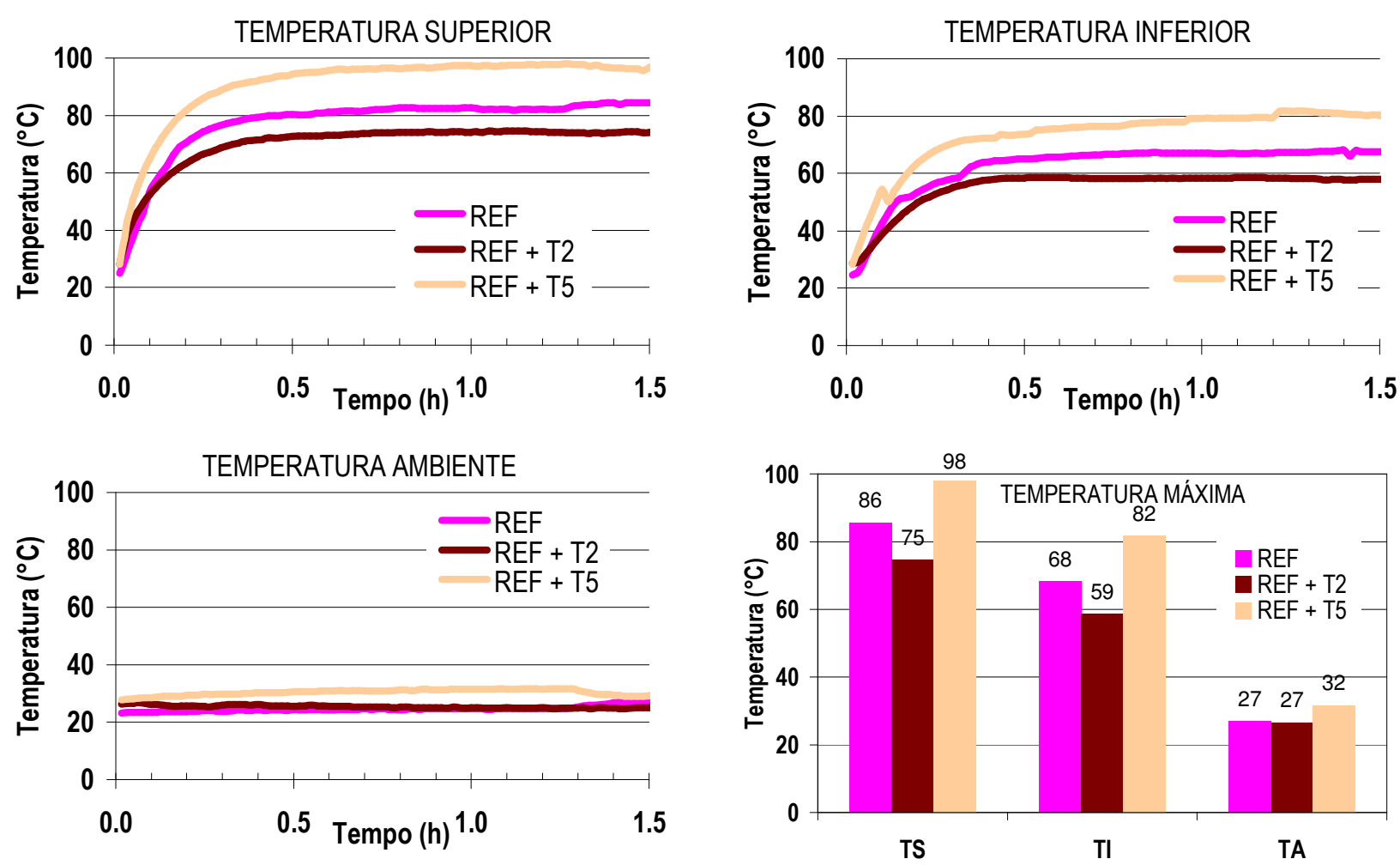

Figura 5.15: Gráfico de temperaturas da tinta marrom refletiva (REF + T2) e convencional (REF + T5) aplicadas na telha de fibrocimento (REF).

Tabela 5.15: Temperaturas máximas e médias das tintas de cor marrom.

\begin{tabular}{|c|c|c|c|c|c|c|c|}
\hline \multirow{2}{*}{ Amostra } & \multirow{2}{*}{ Cor - característica } & \multicolumn{3}{|c|}{ Temp. Máx. $\left({ }^{\circ} \mathrm{C}\right)$} & \multicolumn{3}{|c|}{ Temp. Média $\left({ }^{\circ} \mathrm{C}\right)$} \\
\cline { 3 - 8 } & & TS & TI & TA & TS & TI & TA \\
\hline REF & telha fibrocimento & 85,7 & 68,2 & 26,9 & 77,5 & 62,5 & 24,6 \\
\hline T2 & marrom refletiva & 74,6 & 58,6 & 26,6 & 70,2 & 55,4 & 25,3 \\
\hline T5 & marrom convencional & 97,9 & 81,7 & 31,7 & 90,6 & 73,0 & 30,3 \\
\hline
\end{tabular}

Os resultados mostram que a tinta de cor marrom convencional (REF + T5) apresentou temperaturas superiores quando comparados com a telha de fibrocimento (REF). Conforme a literatura, cores escuras tendem a reter mais calor aumentando a temperatura da superfície.

A tinta de cor marrom refletiva ( $R E F+T 2)$ apresenta um bom desempenho térmico diminuindo a temperatura da superfície (TS) e inferior (TI) da telha de fibrocimento (REF). Observa-se que ambos os corpos-de-prova apresentaram a mesma temperatura no ambiente interno (TA) indicando que o calor estava sendo absorvido pela superfície da telha de fibrocimento e não se concentrava no interior do equipamento. 


\subsubsection{Tinta de cor amarela}

A Figura 5.16 apresenta os resultados de medida de temperatura das tintas de cor amarela e a

Tabela 5.16 os valores das temperaturas máximas e a média das temperaturas medidas pelos termopares.
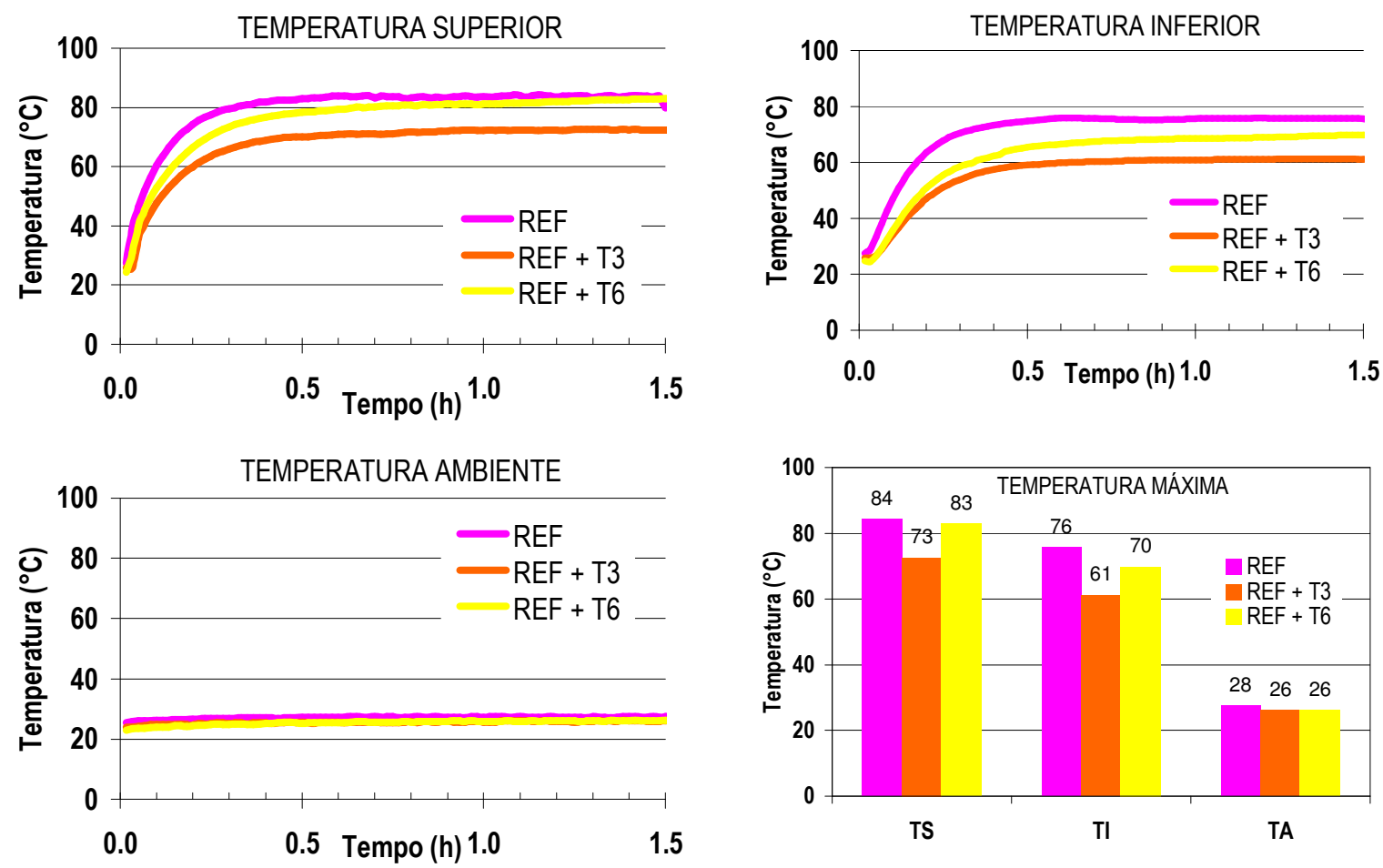

Figura 5.16: Gráfico de temperaturas da tinta amarela refletiva (REF + T3) e convencional (REF + T6) aplicadas na telha de fibrocimento (REF).

Tabela 5.16: Temperaturas máximas e médias das tintas de cor amarela.

\begin{tabular}{|c|c|c|c|c|c|c|c|}
\hline \multirow{2}{*}{ Amostra } & \multirow{2}{*}{ Cor - característica } & \multicolumn{3}{|c|}{ Temp. Máx. $\left({ }^{\circ} \mathrm{C}\right)$} & \multicolumn{3}{|c|}{ Temp. Média $\left({ }^{\circ} \mathrm{C}\right)$} \\
\cline { 3 - 8 } & & TS & TI & TA & TS & TI & TA \\
\hline REF & Telha fibrocimento & 84,3 & 75,9 & 27,5 & 79,6 & 71,0 & 27,1 \\
\hline T3 & amarela refletiva & 72,6 & 61,2 & 26,2 & 67,7 & 56,4 & 25,5 \\
\hline T6 & Amarela convencional & 82,9 & 69,8 & 26,3 & 76,1 & 62,7 & 25,4 \\
\hline
\end{tabular}

Os resultados mostram que a tinta amarela convencional $(R E F+T 6)$ mesmo sendo uma tinta de cor clara, não se mostrou eficiente na diminuição da temperatura da telha de fibrocimento (REF). Já a tinta refletiva de cor amarela $(R E F+T 3)$ melhorou significativamente o desempenho térmico da telha de fibrocimento (REF), diminuindo também a temperatura inferior (TI). 


\subsubsection{Tinta refletiva de cor alumínio}

A Figura 5.17 apresenta os resultados de medida de temperatura das tintas de cor alumínio e a

Tabela 5.17 os valores das temperaturas máximas e a média das temperaturas medidas pelos termopares.
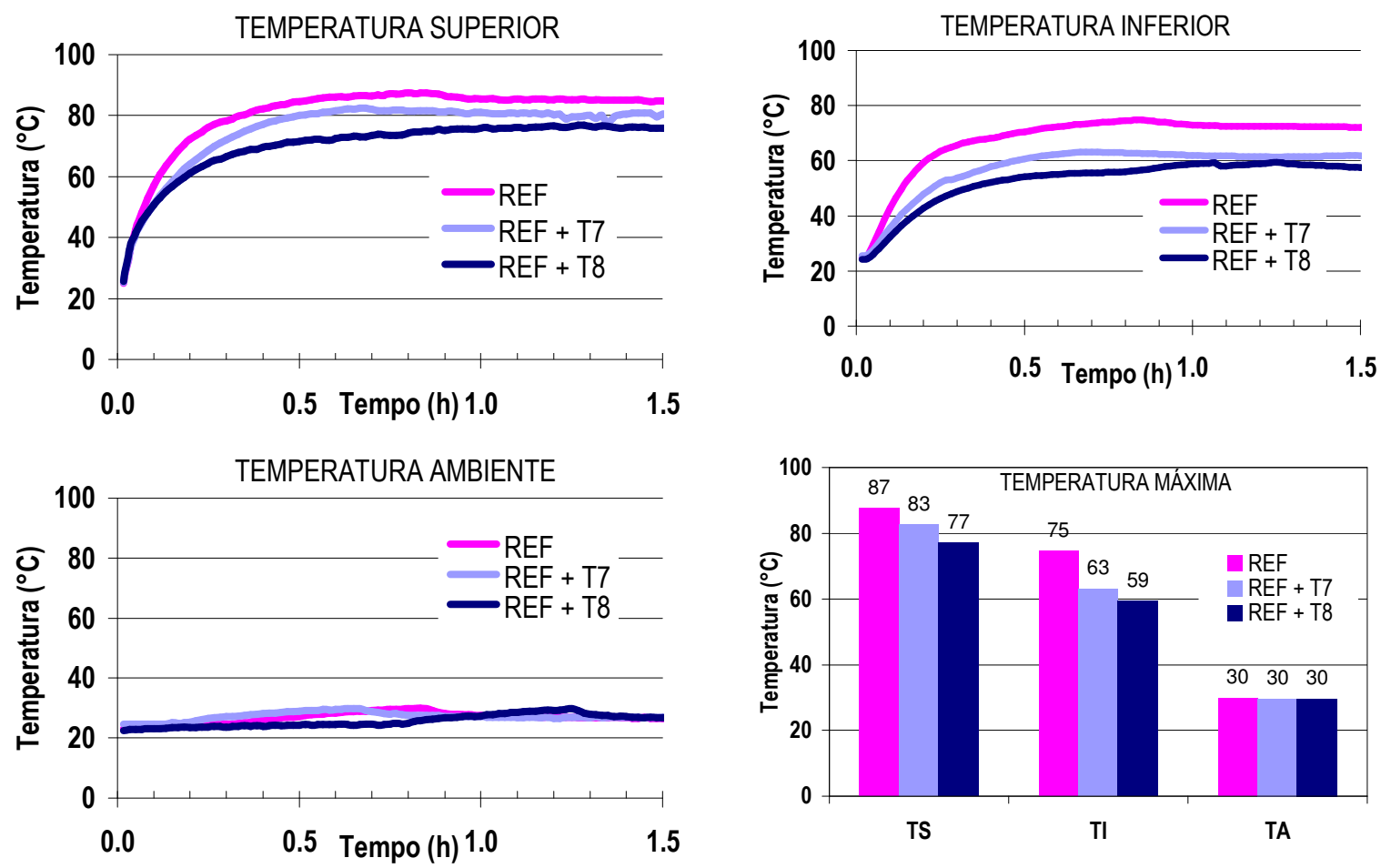

Figura 5.17: Gráfico de temperaturas da tinta alumínio refletiva nacional (REF + T7) e internacional (REF + T8) aplicadas na telha de fibrocimento (REF).

Tabela 5.17: Temperaturas máximas e médias das tintas de cor alumínio.

\begin{tabular}{|c|c|c|c|c|c|c|c|}
\hline \multirow{2}{*}{ Amostra } & \multirow{2}{*}{ Cor - característica } & \multicolumn{3}{|c|}{ Temp. Máx. $\left({ }^{\circ} \mathrm{C}\right)$} & \multicolumn{3}{c|}{ Temp. Média $\left({ }^{\circ} \mathrm{C}\right)$} \\
\cline { 3 - 7 } & & TS & TI & TA & TS & TI & TA \\
\hline REF & telha fibrocimento & 87,5 & 74,7 & 29,9 & 80,7 & 67,8 & 26,8 \\
\hline T7 & alumínio refletiva nacional & 82,5 & 63,2 & 29,7 & 75,5 & 57,5 & 27,2 \\
\hline T8 & alumínio refletiva internacional & 77,0 & 59,4 & 29,7 & 70,6 & 53,0 & 25,8 \\
\hline
\end{tabular}

Ambas as tintas de cor alumínio (REF + T7 e REF + T8) melhoraram o desempenho térmico da telha de fibrocimento (REF) devido à suas características refletivas. A tinta de cor alumínio internacional (T8) quando comparada com a tinta alumínio nacional (T7), apresentou temperaturas inferiores na superfície (TS) e no inferior (TI) da telha de fibrocimento. 


\subsubsection{Tinta refletiva de cor branca com adição de cargas especiais}

A Figura 5.18 apresenta os resultados de medida de temperatura das tintas de cor branca com adição e cargas especiais e a Tabela 5.18 apresenta os valores das temperaturas máximas e a média das temperaturas medidas pelos termopares.
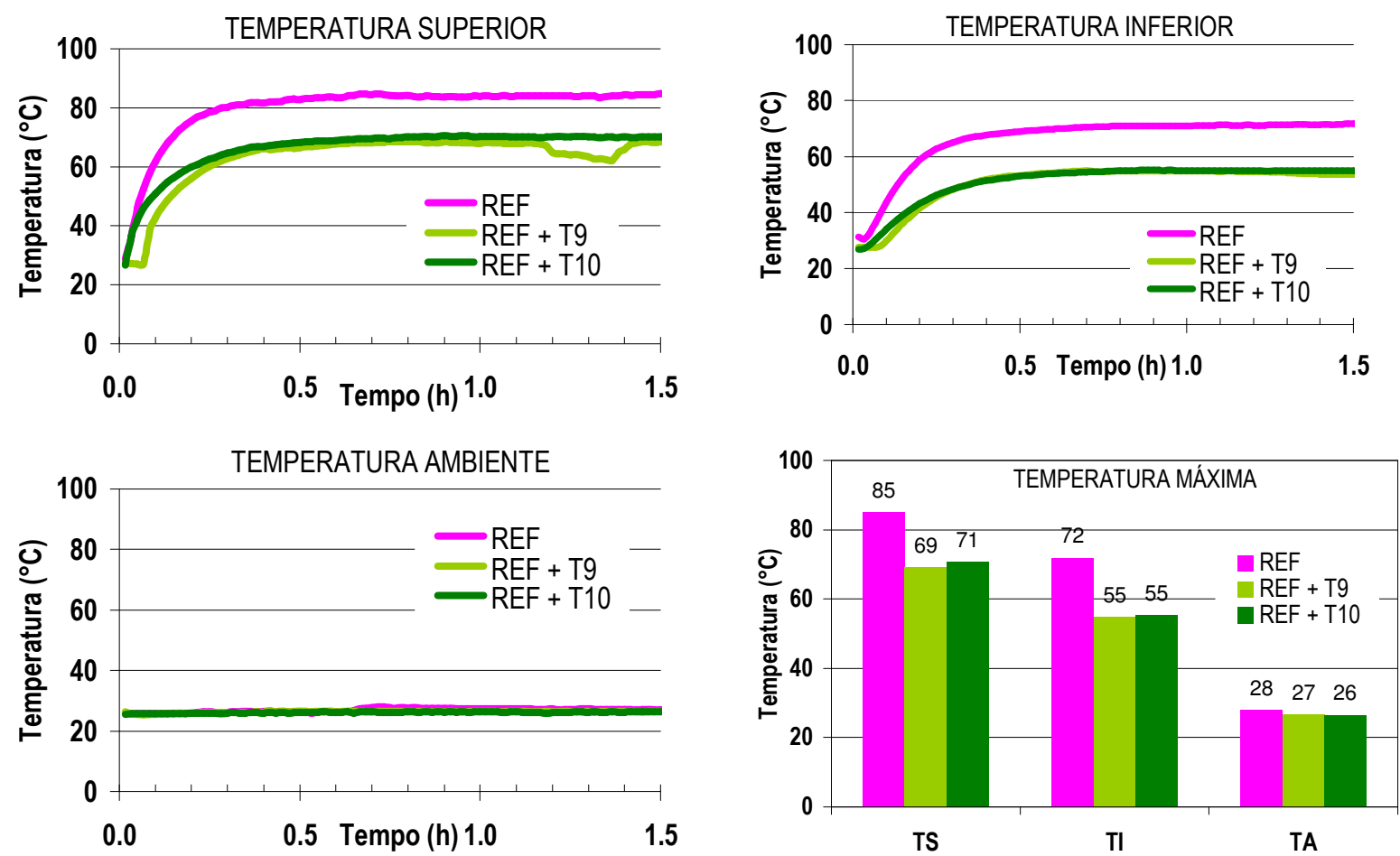

Figura 5.18: Gráfico de temperaturas da tinta branca refletiva com microesferas de vidro (REF + T9) e microesferas cerâmicas (REF + T10) aplicadas na telha de fibrocimento (REF).

Tabela 5.18: Temperaturas máximas e médias das tintas de cor branca (com adição de cargas especiais).

\begin{tabular}{|c|c|c|c|c|c|c|c|}
\hline \multirow{2}{*}{ Amostra } & \multirow{2}{*}{ Cor - característica } & \multicolumn{3}{|c|}{ Temp. Máx. $\left({ }^{\circ} \mathrm{C}\right)$} & \multicolumn{3}{|c|}{ Temp. Média $\left({ }^{\circ} \mathrm{C}\right)$} \\
\cline { 3 - 8 } & & $\mathrm{TS}$ & $\mathrm{TI}$ & $\mathrm{TA}$ & $\mathrm{TS}$ & $\mathrm{TI}$ & $\mathrm{TA}$ \\
\hline REF & telha fibrocimento & 85,0 & 71,9 & 27,9 & 80,2 & 66,6 & 26,8 \\
\hline T9 & $\begin{array}{c}\text { branca refletiva } \\
\text { (microesferas de vidro) }\end{array}$ & 69,3 & 55,0 & 26,7 & 64,6 & 51,4 & 26,3 \\
\hline T10 & $\begin{array}{c}\text { branca refletiva } \\
\text { (microesferas cerâmicas) }\end{array}$ & 70,7 & 55,1 & 26,5 & 67,0 & 51,8 & 26,1 \\
\hline
\end{tabular}

Ambas as tintas refletivas de cor branca (REF + T9 e REF + T10) apresentaram comportamentos térmicos semelhantes embora a suas formulações e cargas adicionais sejam diferentes. As duas tintas diminuíram a temperatura inferior (TI) e a temperatura superior (TS) da telha de 
fibrocimento (REF) melhorando o seu desempenho térmico. A temperatura do ambiente interno (TA) mostra que o calor estava sendo absorvido pelos corpos-de-prova e não estava se acumulando no interior do equipamento, o que aqueceria a telha por convecção.

\subsection{Ensaio em campo: efeito da radiação solar na temperatura de protótipos expostos em ambiente natural}

\subsubsection{Tinta de cor branca}

Os dias determinados para a análise dos dados de temperatura para os grupos da tinta de cor branca foram os dias 16 e 17 de março de 2007. As variáveis climáticas destes dias são apresentadas na Tabela 5.19, sendo as médias obtidas calculadas entre o período das 6:00h às 18:00h.

Tabela 5.19: Dados climáticos dos dias 16 e 17 de março de 2007.

\begin{tabular}{|c|c|c|}
\hline Dia & $16 / 03 / 07$ & $17 / 03 / 07$ \\
\hline Temp. Média $\left({ }^{\circ} \mathrm{C}\right)$ & 24 & 23 \\
\hline Temp. Máx $\left({ }^{\circ} \mathrm{C}\right)$ & 29 & 27 \\
\hline Temp. Mín. $\left({ }^{\circ} \mathrm{C}\right)$ & 19 & 20 \\
\hline UR $(\%)$ & 86 & 91 \\
\hline Precip. $(\mathrm{mm})$ & 0 & 0 \\
\hline Rad. $\left(\mathrm{Wh} / \mathrm{m}^{2}\right)$ & 3631 & 3226 \\
\hline
\end{tabular}

Na Figura 5.19 são apresentadas as curvas de temperatura dos protótipos de cobertura de fibrocimento sem pintura (REF), de pintura branca refletiva (P1) e de pintura branca convencional (P4). Na Figura 5.20 são apresentados as curvas de diferença de temperatura superficial entre 0 protótipo REF e os protótipos $\mathrm{P} 1\left(\Delta \mathrm{T}=\mathrm{T}_{\mathrm{REF}}-\mathrm{T}_{\mathrm{P} 1}\right)$ e $\mathrm{P} 4\left(\Delta \mathrm{T}=\mathrm{T}_{\mathrm{REF}}-\mathrm{T}_{\mathrm{P} 4}\right)$. Na Tabela 5.20 são apresentados os valores máximos e médios das temperaturas monitoradas durante os dias 16 e 17 de março. 


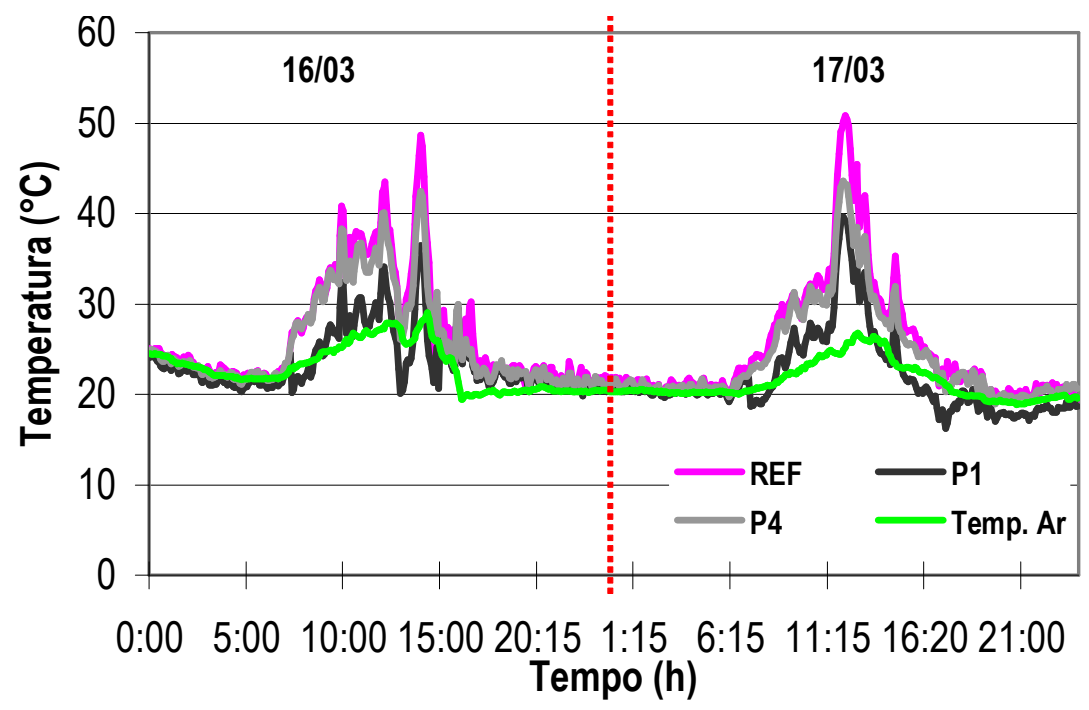

Figura 5.19: Gráfico das temperaturas da superfície das coberturas dos protótipos REF, P1 e P4 e do ar externo.

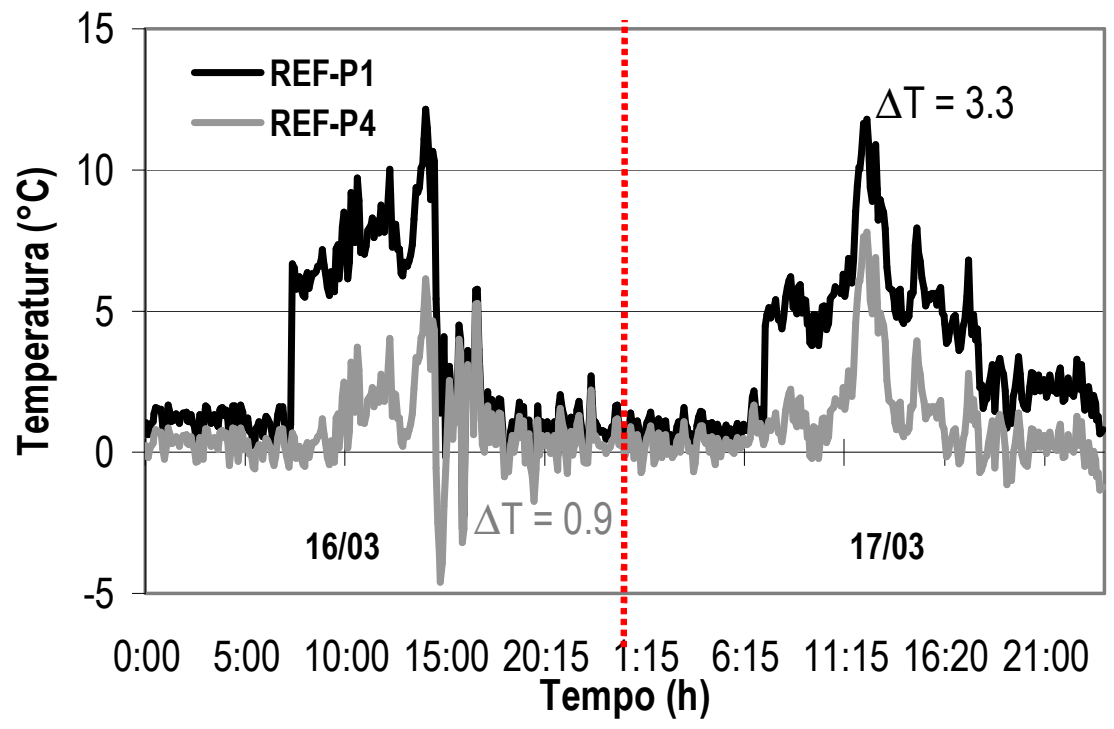

Figura 5.20: Gráfico da diferença de temperatura superficial entre o protótipo de REF e os protótipos P1 e P4.

Tabela 5.20: Temperaturas máximas e médias das coberturas com tintas de cor branca.

\begin{tabular}{|c|c|c|c|c|c|c|}
\hline Data & \multicolumn{3}{|c|}{$16 / 03$} & \multicolumn{3}{c|}{$17 / 03$} \\
\hline Protótipos & REF & P1 & P4 & REF & P1 & P4 \\
\hline Termopares & \multicolumn{7}{|c|}{ Temp. Média $\left({ }^{\circ} \mathrm{C}\right)$} \\
\hline TS & 31 & 25 & 30 & 30 & 24 & 28 \\
\hline TI & 28 & 30 & 30 & 27 & 26 & 26 \\
\hline TA & 29 & 28 & 28 & 27 & 26 & 26 \\
\hline Termopares & \multicolumn{7}{|c|}{ Temp. Máx. $\left({ }^{\circ} \mathrm{C}\right)$} \\
\hline TS & 49 & 36 & 43 & 51 & 39 & 44 \\
\hline TI & 41 & 37 & 38 & 40 & 34 & 35 \\
\hline TA & 36 & 35 & 33 & 34 & 32 & 32 \\
\hline
\end{tabular}


Todos os protótipos apresentaram temperaturas mais elevadas em relação à temperatura do ambiente externo. 0 protótipo com cobertura de pintura refletiva (P1) apresenta temperaturas superficiais mais baixas $\left(\Delta \mathrm{T}_{\text {médio }}=3.3\right)$ em relação ao protótipo com cobertura de pintura convencional (P4), que apresentou um $\Delta \mathrm{T}_{\text {médio }}=0.9$. Portanto a tinta convencional apesar da cor branca não melhorou o comportamento térmico da telha de fibrocimento (REF).

\subsubsection{Tinta de cor marrom}

Os dias determinados para a análise dos dados de temperatura para os grupos da tinta de cor marrom foram os dias 03 e 04 de abril de 2007. As variáveis climáticas destes dias são apresentadas na Tabela 5.21 , sendo as médias obtidas calculadas entre o período das 6:30h às 17:30h.

Tabela 5.21: Dados climáticos dos dias 03 e 04 de abril de 2007.

\begin{tabular}{|c|c|c|}
\hline Dia & $03 / 04 / 2007$ & $04 / 04 / 2007$ \\
\hline Temp Média $\left({ }^{\circ} \mathrm{C}\right)$ & 27 & 25 \\
\hline Temp Máx $\left({ }^{\circ} \mathrm{C}\right)$ & 31 & 27 \\
\hline Temp Mín $\left({ }^{\circ} \mathrm{C}\right)$ & 21 & 21 \\
\hline UR $(\%)$ & 73 & 86 \\
\hline Precip $(\mathrm{mm})$ & 0 & 0 \\
\hline Rad. $(\mathrm{Wh} / \mathrm{m} 2)$ & 4776 & 4982 \\
\hline
\end{tabular}

Na Figura 5.21 são apresentadas as curvas de temperatura dos protótipos de cobertura de fibrocimento sem pintura (REF), de pintura marrom refletiva (P2) e de pintura marrom convencional (P5). Na Figura 5.22 são apresentados as curvas de diferença de temperatura superficial entre o protótipo REF e os protótipos $P 2\left(\Delta T=T_{R E F}-T_{P 2}\right)$ e $P 5\left(\Delta T=T_{R E F}-T_{P 5}\right)$. Na Tabela 5.22 são apresentados os valores máximos e médios das temperaturas monitoradas durante os dias 03 e 04 de abril. 


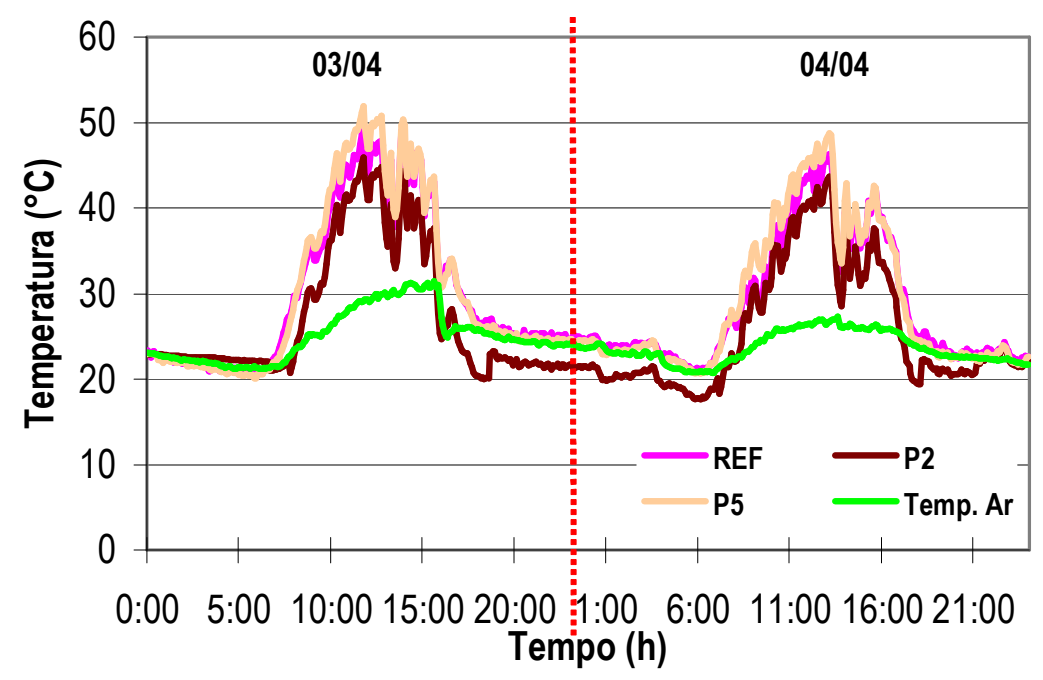

Figura 5.21: Gráfico das temperaturas da superfície das coberturas dos protótipos REF, P2 e P5 e do ar externo.

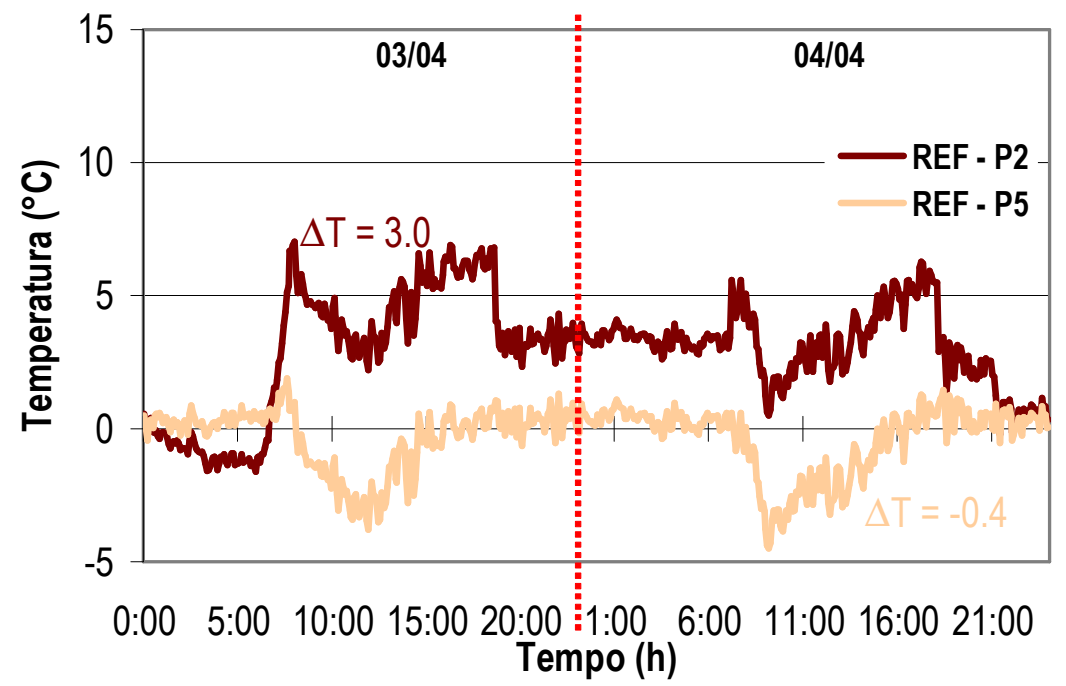

Figura 5.22: Gráfico da diferença de temperatura superficial entre o protótipo REF e os protótipos P2 e P5.

Tabela 5.22: Temperaturas máximas e médias das coberturas com tintas de cor marrom.

\begin{tabular}{|c|c|c|c|c|c|c|}
\hline Data & \multicolumn{3}{|c|}{$03 / 04$} & \multicolumn{3}{|c|}{$04 / 04$} \\
\hline Protótipos & REF & P2 & P5 & REF & P2 & P5 \\
\hline Termopares & \multicolumn{7}{|c|}{ Temp. Média $\left({ }^{\circ} \mathrm{C}\right)$} \\
\hline TS & 37 & 32 & 37 & 31 & 30 & 31 \\
\hline TI & 33 & 36 & 36 & 28 & 30 & 30 \\
\hline TA & 32 & 31 & 32 & 28 & 27 & 28 \\
\hline Termopares & \multicolumn{7}{|c|}{ Temp. Máx. $\left({ }^{\circ} \mathrm{C}\right)$} \\
\hline TS & 49 & 46 & 52 & 46 & 44 & 49 \\
\hline TI & 47 & 48 & 49 & 42 & 43 & 45 \\
\hline TA & 38 & 37 & 37 & 34 & 34 & 34 \\
\hline
\end{tabular}


A variação da temperatura superficial dos protótipos mostra que as temperaturas de todos os protótipos estão acima da temperatura do ar externo. A temperatura do protótipo de cobertura convencional (P5) permaneceu mais elevada em relação aos protótipos com cobertura de pintura refletiva marrom (P2) e de fibrocimento sem pintura (REF).

O protótipo com cobertura de pintura marrom refletiva (P2) apresentou temperaturas superficiais inferiores $\left(\Delta \mathrm{T}_{\text {médio }}=3\right)$ em relação ao protótipo com cobertura de pintura marrom convencional (P5), comprovando a eficácia da pintura refletiva de cor marrom na redução da a temperatura superficial da telha de fibrocimento (REF). Na curva da variação de temperatura do protótipo de referência (REF) e do protótipo com cobertura convencional de cor marrom (P5) observa-se um $\Delta T_{\text {médio }}=-0.4$, mostrando que este tipo de tinta aumentou a temperatura superficial da telha de fibrocimento.

\subsubsection{Tinta de cor amarela}

Os dias determinados para a análise dos dados de temperatura, para os grupos da tinta de cor amarela foram os dias 18 e 20 de maio de 2007. As variáveis climáticas destes dias são apresentadas na Tabela 5.23, sendo as médias obtidas, calculadas entre o período das 6:30h às 17:30h.

Tabela 5.23: Dados climáticos dos dias 18 e 20 de maio de 2007.

\begin{tabular}{|c|c|c|}
\hline Dia & $18 / 05 / 2007$ & $20 / 05 / 2007$ \\
\hline Temp Média $\left({ }^{\circ} \mathrm{C}\right)$ & 23 & 19 \\
\hline Temp Máx $\left({ }^{\circ} \mathrm{C}\right)$ & 28 & 22 \\
\hline Temp Mín $\left({ }^{\circ} \mathrm{C}\right)$ & 17 & 16 \\
\hline UR $(\%)$ & 80 & 89 \\
\hline Precip $(\mathrm{mm})$ & 0 & 0 \\
\hline Rad. $($ Wh/m2) & 3540 & 3098 \\
\hline
\end{tabular}

Na Figura 5.23 são apresentadas as curvas de temperatura dos protótipos de cobertura de fibrocimento sem pintura (REF), de pintura amarela refletiva (P3) e de pintura amarela convencional (P6). Na Figura 5.24 são apresentados as curvas de diferença de temperatura 
superficial entre o protótipo REF e os protótipos $\mathrm{P} 3\left(\Delta T=\mathrm{T}_{\mathrm{REF}}-\mathrm{T}_{\mathrm{P} 3}\right)$ e $\mathrm{P} 6\left(\Delta \mathrm{T}=\mathrm{T}_{\mathrm{REF}}-\mathrm{T}_{\mathrm{P} 6}\right)$. Na Tabela 5.24 são apresentados os valores máximos e médios das temperaturas monitoradas durante os dias 18 e 20 de maio.

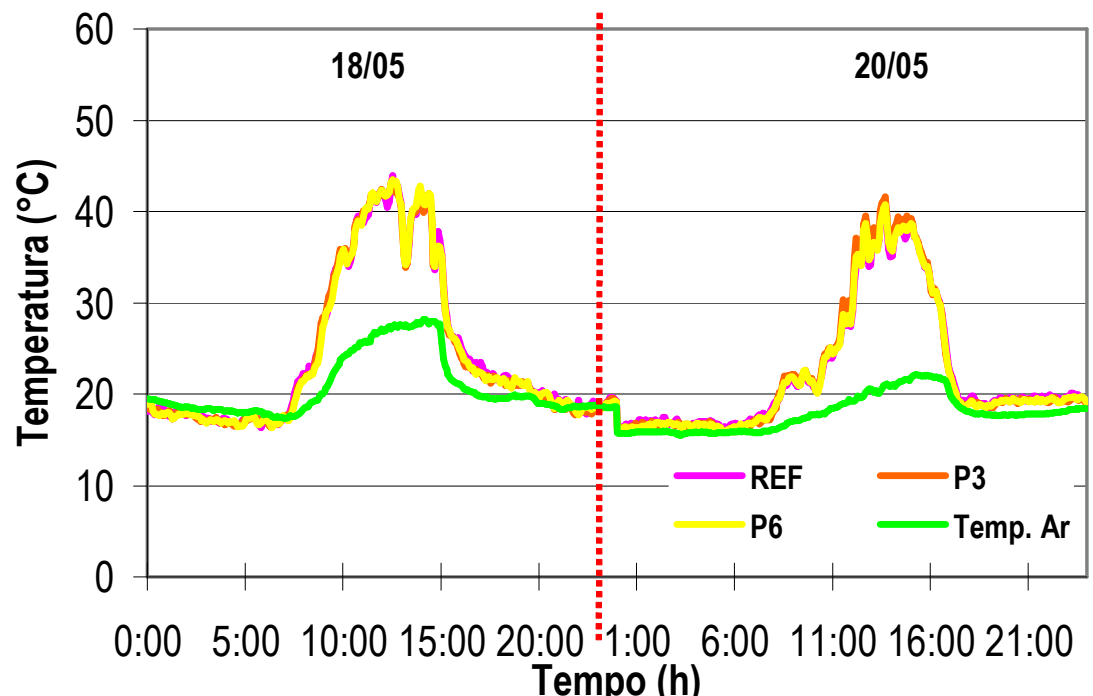

Figura 5.23: Gráfico das temperaturas da superfície das coberturas dos protótipos REF, P3 e P6 e do ar externo.

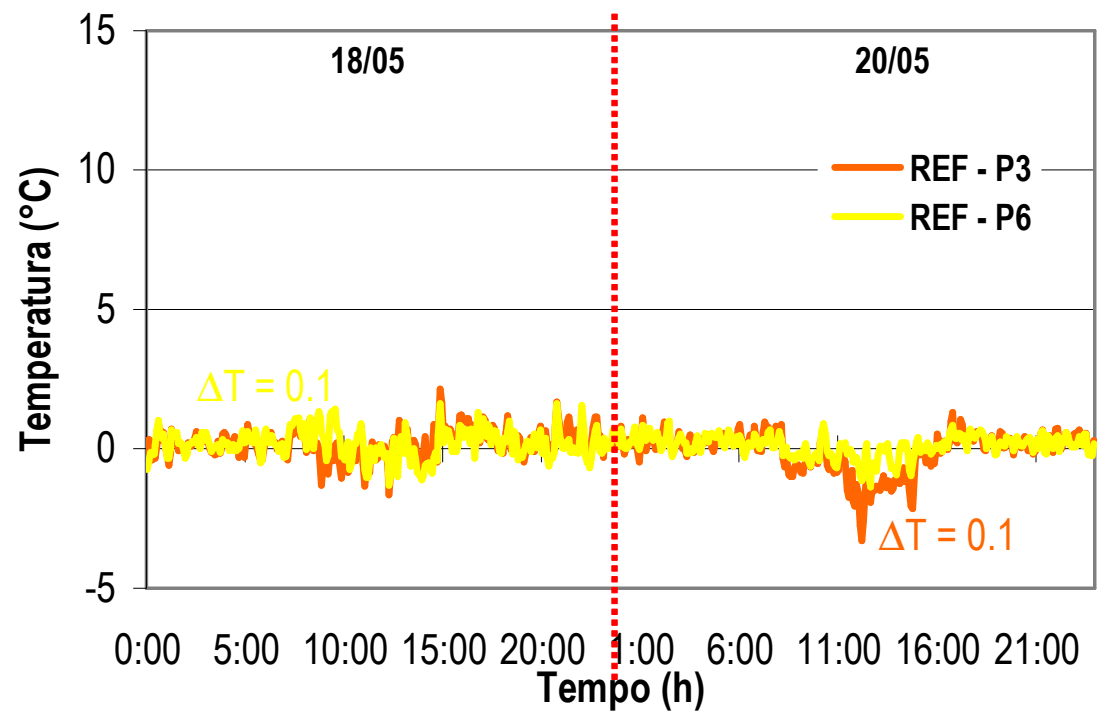

Figura 5.24: Gráfico da diferença de temperatura superficial entre o protótipo REF e os protótipos P3 e P6. 
Tabela 5.24: Temperaturas máximas e médias das coberturas com tintas de cor amarela.

\begin{tabular}{|c|c|c|c|c|c|c|}
\hline Data & \multicolumn{3}{|c|}{$18 / 05$} & \multicolumn{3}{|c|}{$20 / 05$} \\
\hline Protótipos & REF & P3 & P6 & REF & P3 & P6 \\
\hline Termopares & \multicolumn{7}{|c|}{ Temp. Média $\left({ }^{\circ} \mathrm{C}\right)$} \\
\hline TS & 24 & 24 & 24 & 22 & 22 & 22 \\
\hline TI & 23 & 24 & 24 & 21 & 21 & 22 \\
\hline TA & 23 & 23 & 23 & 21 & 20 & 20 \\
\hline Termopares & 44 & 44 & 44 & 40 & 41 & 42 \\
\hline TS & 37 & 39 & 41 & 33 & 34 & 36 \\
\hline TI & 33 & 32 & 32 & 28 & 28 & 29 \\
\hline TA & 33 &
\end{tabular}

Observa-se que tanto o protótipo com cobertura de pintura amarela refletiva (P3), quanto o protótipo de pintura convencional (P6) apresentaram temperaturas próximas ao protótipo de cobertura sem pintura (REF). As tintas amarelas, independentes de serem refletivas ou convencionais, não se mostraram eficientes na diminuição da temperatura da telha de fibrocimento em campo. Praticamente não houve alteração da temperatura superficial entre os protótipos onde se observa um $\Delta \mathrm{T}_{\text {médio }}=0.1$.

\subsubsection{Tinta refletiva de cor alumínio}

Os dias determinados para a análise dos dados de temperatura, para os grupos da tinta de cor alumínio foram os dias 11 e 12 de agosto de 2007. As variáveis climáticas destes dias são apresentadas na Tabela 5.25 , sendo as médias obtidas calculadas entre o período das 6:30h às $17: 30 \mathrm{~h}$.

Tabela 5.25: Dados climáticos dos dias 11 e 12 de agosto de 2007.

\begin{tabular}{|c|c|c|}
\hline Dia & $11 / 8 / 2007$ & $12 / 8 / 2007$ \\
\hline Temp Média $\left({ }^{\circ} \mathrm{C}\right)$ & 18 & 17 \\
\hline Temp Máx $\left({ }^{\circ} \mathrm{C}\right)$ & 23 & 21 \\
\hline Temp Mín $\left({ }^{\circ} \mathrm{C}\right)$ & 14 & 14 \\
\hline UR $(\%)$ & 81 & 88 \\
\hline Precip $(\mathrm{mm})$ & 0 & 0 \\
\hline Rad. $(\mathrm{Wh} / \mathrm{m} 2)$ & 3340 & 3063 \\
\hline
\end{tabular}

$\mathrm{Na}$ Figura 5.25 são apresentadas as curvas de temperatura superficial dos protótipos de 
cobertura de fibrocimento sem pintura (REF), de pintura alumínio refletiva nacional (P7) e de pintura alumínio refletiva internacional (P8). Na Figura 5.26 são apresentados as curvas de diferença de temperatura superficial entre o protótipo REF e os protótipos $P 7\left(\Delta T=T_{R E F}-T_{P 7}\right)$ e P8 $\left(\Delta T=T_{R E F}-T P 8\right)$. Na Tabela 5.26 são apresentados os valores máximos e médios das temperaturas monitoradas durante os dias 11 e 12 de agosto.

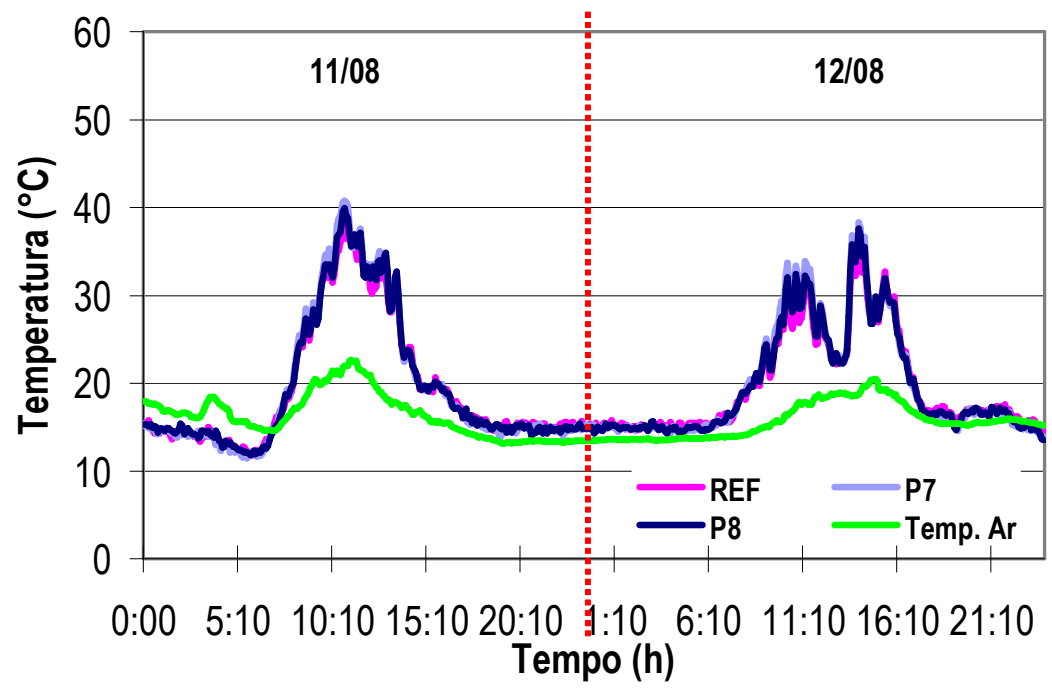

Figura 5.25: Gráfico das temperaturas da superfície das coberturas dos protótipos REF, P7 e P8 e do ar externo.

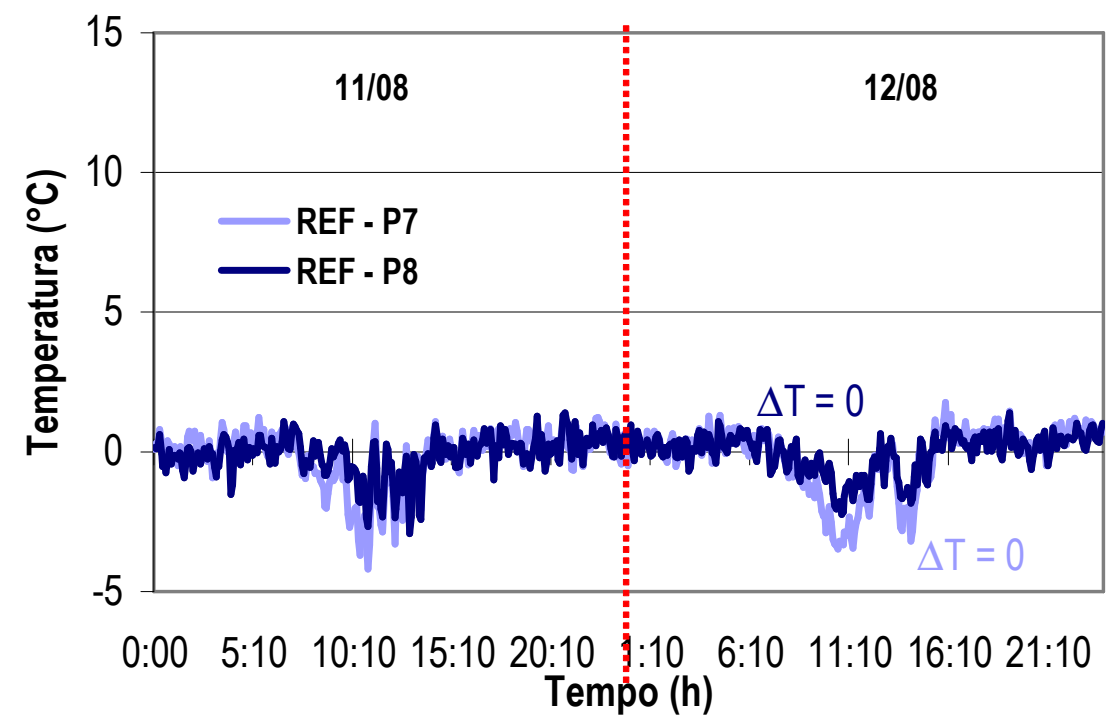

Figura 5.26: Gráfico da diferença de temperatura superficial entre o protótipo REF e os protótipos P7 e P8. 
Tabela 5.26: Temperaturas máximas e médias das coberturas com tintas refletivas de cor alumínio.

\begin{tabular}{|c|c|c|c|c|c|c|}
\hline Data & \multicolumn{3}{|c|}{$11 / 08$} & \multicolumn{3}{|c|}{$12 / 08$} \\
\hline Protótipos & REF & P7 & P8 & REF & P7 & P8 \\
\hline Termopares & \multicolumn{7}{|c|}{ Temp. Média $\left({ }^{\circ} \mathrm{C}\right)$} \\
\hline TS & 25 & 26 & 25 & 24 & 25 & 25 \\
\hline TI & 21 & 21 & 22 & 22 & 21 & 22 \\
\hline TA & 22 & 21 & 21 & 21 & 21 & 21 \\
\hline Termopares & \multicolumn{7}{|c|}{ Temp. Máx. $\left({ }^{\circ} \mathrm{C}\right)$} \\
\hline TS & 44 & 41 & 40 & 43 & 39 & 38 \\
\hline TI & 29 & 29 & 28 & 27 & 27 & 26 \\
\hline TA & 30 & 29 & 29 & 26 & 25 & 26 \\
\hline
\end{tabular}

O protótipo com cobertura de pintura refletiva internacional (P8) e o protótipo com cobertura de pintura refletiva nacional $(\mathrm{P} 7)$ apresentaram temperaturas superficiais equivalentes quando comparada ao protótipo sem pintura (REF). Ambas as pinturas refletivas de cor alumínio não apresentaram um desempenho térmico satisfatório na tentativa de diminuir a temperatura do protótipo sem pintura (REF), já que a variação da temperatura superficial foi praticamente nula $\left(\Delta \mathrm{T}_{\text {médio }}=0\right)$.

\subsubsection{Tinta refletiva de cor branca com adição de cargas especiais}

Os dias determinados para a análise dos dados de temperatura, para os grupos da tinta de cor branca refletivas com cargas especiais foram os dias 14 e 15 de setembro de 2007 . As variáveis climáticas destes dias são apresentadas na Tabela 5.27, sendo as médias obtidas calculadas entre o período das 6:00h às 18:00h.

Tabela 5.27: Dados climáticos dos dias 14 e 15 de setembro de 2007.

\begin{tabular}{|c|c|c|}
\hline Dia & $14 / 9 / 2007$ & $15 / 9 / 2007$ \\
\hline Temp Média $\left({ }^{\circ} \mathrm{C}\right)$ & 25 & 26 \\
\hline Temp Máx $\left({ }^{\circ} \mathrm{C}\right)$ & 30 & 30 \\
\hline Temp Mín $\left({ }^{\circ} \mathrm{C}\right)$ & 16 & 17 \\
\hline UR $(\%)$ & 53 & 47 \\
\hline Precip $(\mathrm{mm})$ & 0 & 0 \\
\hline Rad. $(\mathrm{Wh} / \mathrm{m} 2)$ & 5512 & 5536 \\
\hline
\end{tabular}

Na Figura 5.27 são apresentadas as curvas de temperatura superficial dos protótipos de 
cobertura de fibrocimento sem pintura (REF), de pintura branca refletiva com microesferas de vidro (P9) e de pintura branca refletiva com microesferas cerâmicas (P10). Na Figura 5.28 são apresentados as curvas de diferença de temperatura superficial entre o protótipo REF e os protótipos P9 $\left(\Delta T=T_{R E F}-T_{P 9}\right)$ e $P 10\left(\Delta T=T_{R E F}-T_{P 10}\right)$. Na Tabela 5.28 são apresentados os valores máximos e médios das temperaturas monitoradas durante os dias 14 e 15 de setembro.

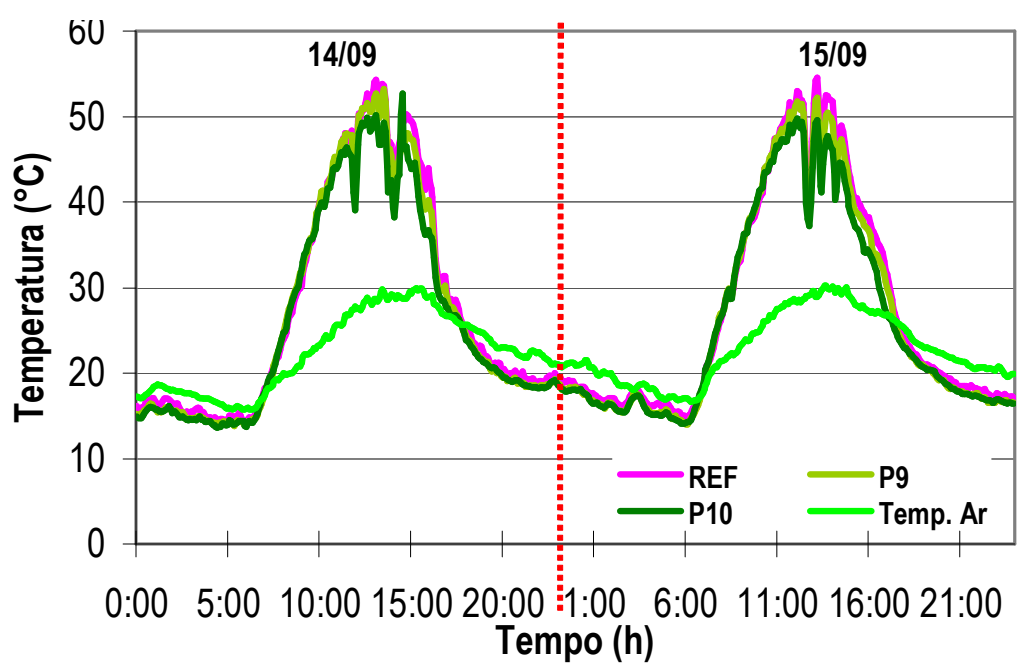

Figura 5.27: Gráfico das temperaturas da superfície das coberturas dos protótipos REF, P9 e P10 e do ar externo.

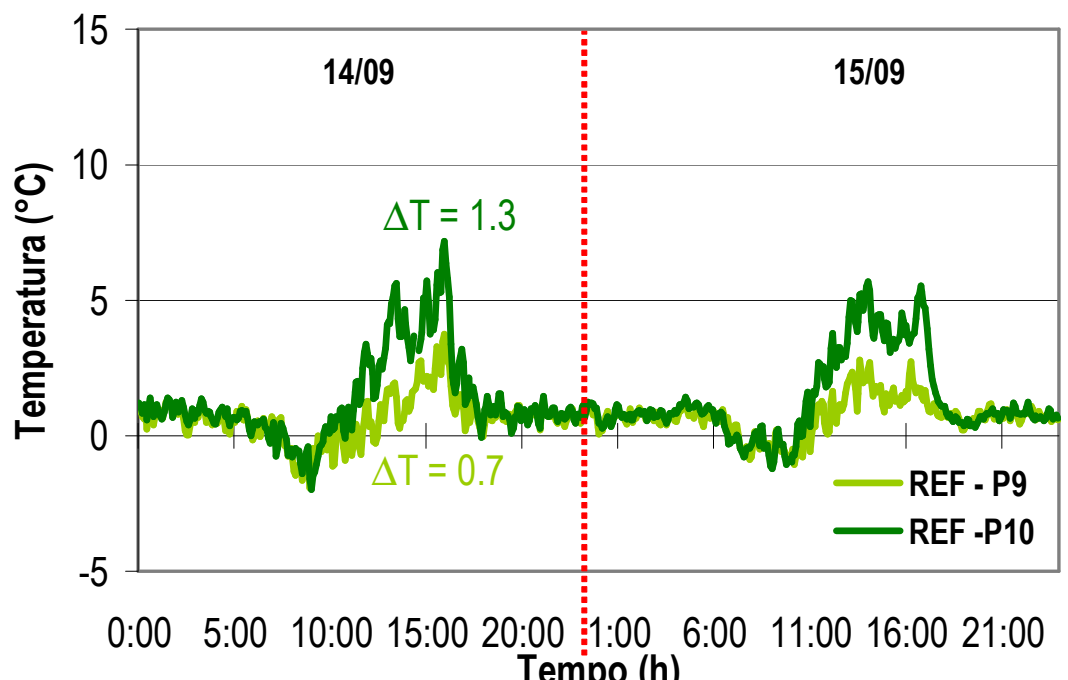

Figura 5.28: Gráfico da diferença de temperatura superficial entre o protótipo REF e os protótipos P9 e P10. 
Tabela 5.28: Temperaturas máximas e médias das coberturas com tintas refletivas de cor branca com cargas especiais.

\begin{tabular}{|c|c|c|c|c|c|c|}
\hline Data & \multicolumn{3}{|c|}{$14 / 09$} & \multicolumn{3}{c|}{$15 / 09$} \\
\hline Protótipos & REF & P9 & P10 & REF & P9 & P10 \\
\hline Termopares & \multicolumn{7}{|c|}{ Temp. Média $\left({ }^{\circ} \mathrm{C}\right)$} \\
\hline TS & 38 & 36 & 36 & 39 & 37 & 37 \\
\hline TI & 34 & 33 & 30 & 35 & 34 & 30 \\
\hline TA & 31 & 29 & 28 & 32 & 33 & 29 \\
\hline Termopares & \multicolumn{7}{|c|}{ Temp. Máx. $\left({ }^{\circ} \mathrm{C}\right)$} \\
\hline TS & 55 & 53 & 53 & 55 & 50 & 50 \\
\hline TI & 46 & 43 & 38 & 46 & 45 & 39 \\
\hline TA & 39 & 32 & 35 & 40 & 33 & 35 \\
\hline
\end{tabular}

Os protótipos com cobertura de pintura refletiva branca (P9 e P10), independente da carga adicionada à formulação, diminuíram a temperatura da cobertura do protótipo sem pintura (REF). Observa-se que a variação da temperatura superficial não foi significativa, pois o protótipo com cobertura de pintura refletiva com microesferas cerâmicas (P10) apresentou um de $\Delta \mathrm{T}_{\text {médio }}=1.3 \mathrm{e}$ o protótipo com cobertura de pintura refletiva com microesferas de vidro (P9) apresentou um $\Delta \mathrm{T}_{\text {médio }}=0.7$.

\subsection{Influência da formulação das tintas no desempenho térmico}

As tintas com pigmentos refletivos ou cargas especiais podem modificar o comportamento térmico das telhas de fibrocimento. O pigmento refletivo forma uma película com maior poder refletivo à radiação infravermelha e as cargas especiais adicionadas melhoram 0 isolamento térmico da telha auxiliando na diminuição da temperatura. As diferenças observadas entre uma tinta refletiva e uma tinta convencional através da análise dos ensaios realizados estão apresentadas na Tabela 5.29.

Tabela 5.29: Tabela comparativa entre as tintas refletivas e convencionais do estudo.

\begin{tabular}{|c|c|c|}
\hline Característica & Tinta convencional & Tinta refletiva \\
\hline Cor & Claras e escuras & Claras e escuras \\
\hline Acabamento & Fosco, acetinado e semibrilho & Fosco, acetinado e semibrilho \\
\hline Refletância a radiação infravermelha & Alta somente em cores claras & Alta em todas as cores \\
\hline
\end{tabular}




\subsection{Refletância x Cor}

A análise de cor mostrou que os dois tipos de tinta (convencional e refletiva) apresentaram cores correspondentes, mas valores de refletâncias diferentes. As tintas designadas como refletivas apresentaram altos valores de refletância, principalmente na região da radiação infravermelha.

As curvas da refletância em função do comprimento de onda na região do visivel (responsável pelas cores) mostram que as tintas, visualmente de mesma coloração, apresentam espectros praticamente coincidentes revelando que as cores das tintas estudadas são correspondentes. Este fato é comprovado pelos resultados de medida de cor instrumental que mostraram que as tintas refletivas coloridas apresentaram cores bastante semelhantes em relação às tintas acrílicas convencionais, mostrando que é possível a produção de tintas refletivas coloridas com propriedades refletivas.

Na Figura 5.29 são apresentados os valores de refletância em relação a cor das tintas do estudo. Os resultados de refletância correlacionados com as cores das tintas do estudo são apresentados na Figura 5.30.

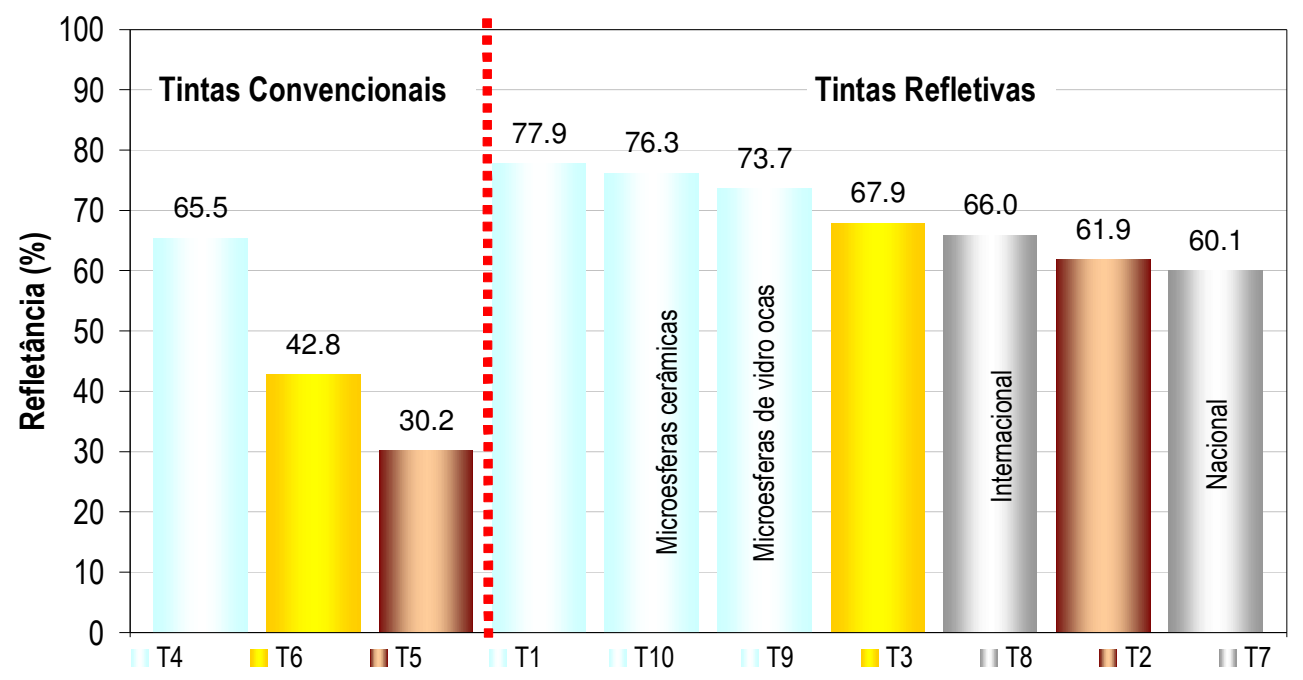

Figura 5.29: Refletância total (\%) das películas de tinta. 


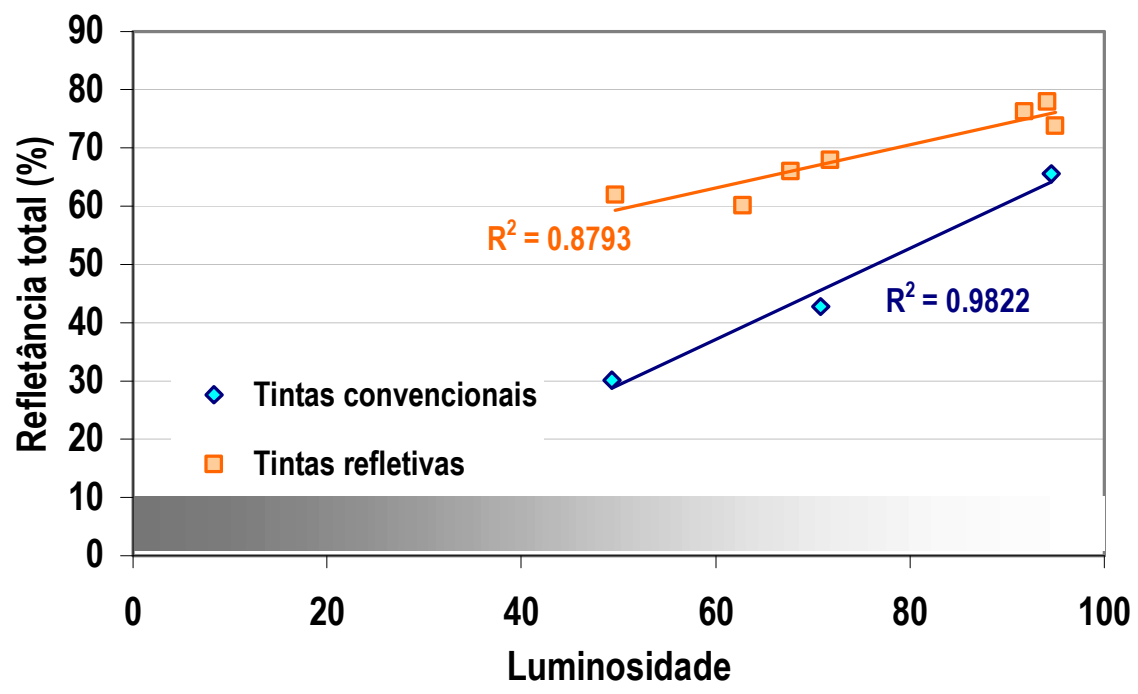

Figura 5.30: Correlação entre luminosidade e refletância total (\%) das películas de tinta.

Observa-se nas tintas convencionais que quanto mais clara é a cor da tinta, maior é o valor da sua refletância. Nas tintas refletivas não há influência da cor na refletância das películas, independente da sua cor ser clara ou escura.

\subsection{Refletância x Temperatura}

No geral, as tintas refletivas, independente da sua cor, apresentaram valores altos de refletância na região do infravermelho e temperaturas mais baixas, quando comparadas com as tintas convencionais. Por exemplo, a tinta convencional de cor marrom não se mostrou eficiente na refletância à radiação infravermelha. Os resultados do estudo do efeito da radiação infravermelha e da radiação solar na temperatura dos corpos-de-prova de fibrocimento pintado e dos protótipos com coberturas pintadas com tinta marrom convencional mostraram que muitas vezes a telha que recebeu a aplicação desta tinta atingiu temperaturas mais elevadas em relação à telha de fibrocimento sem pintura. Esta condição é característica de cores escuras quando expostas a este tipo de radiação.

As telhas de fibrocimento que receberam pintura com tintas refletivas apresentaram temperaturas na superfície da cobertura inferiores, quando comparadas com os protótipos que 
receberam pinturas com tintas convencionais em suas coberturas, ou com os protótipos com coberturas sem pintura. As temperaturas medidas em campo não foram as esperadas para as tintas refletivas, já que as mesmas apresentaram valores de refletância acima de $65 \%$.

Na Figura 5.31 é apresentado um gráfico de correlação entre a refletância total (\%) e a temperatura medida através da exposição à radiação solar (em campo) e a radiação infravermelha (simulada em laboratório).

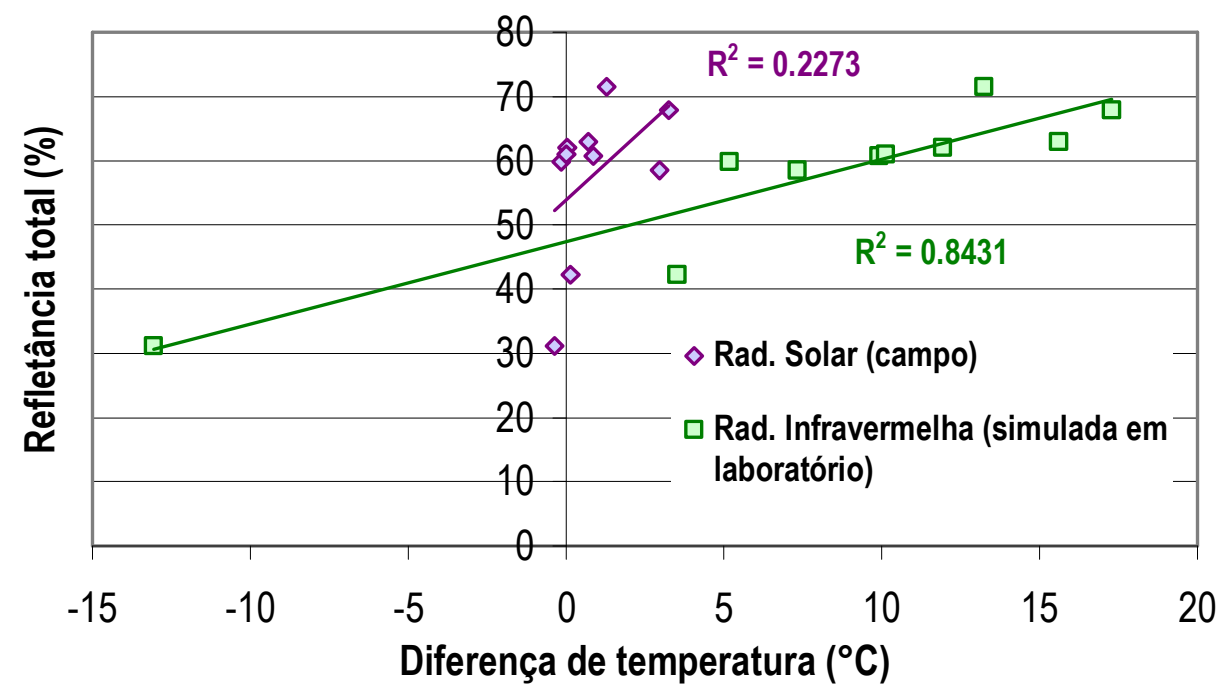

Figura 5.31: Gráfico de correlação entre a diferença de temperatura da telha de fibrocimento (REF) e dos corpos-de-prova e protótipos pintados com as tintas do estudo.

Na Tabela 5.30 são apresentados os valores de refletância total (\%) e da diferença de temperatura entre a telha de fibrocimento e as telhas pintadas com as tintas do estudo. 
Tabela 5.30: Valores de refletância total (\%) e da diferença de temperatura média entre a telha de fibrocimento e as telhas pintadas com as tintas do estudo.

\begin{tabular}{|c|c|c|c|}
\hline \multirow{2}{*}{ Protótipo } & Refletância & \multicolumn{2}{|c|}{$\Delta \mathrm{T}_{\text {médio }}\left({ }^{\circ} \mathrm{C}\right)$} \\
\cline { 3 - 4 } & $(\%)$ & Rad. Simulada & Rad. Solar \\
\hline P1 & 67.9 & 17.3 & 3.3 \\
\hline P2 & 58.5 & 7.3 & 3.0 \\
\hline P3 & 62.1 & 11.9 & 0.1 \\
\hline P4 & 60.7 & 9.9 & 0.9 \\
\hline P5 & 31.2 & -13.1 & -0.4 \\
\hline P6 & 42.3 & 3.5 & 0.1 \\
\hline P7 & 59.8 & 5.2 & 0 \\
\hline P8 & 61.0 & 10.1 & 0 \\
\hline P9 & 62.9 & 15.6 & 0.7 \\
\hline P10 & 71.6 & 13.2 & 1.3 \\
\hline
\end{tabular}

Observa-se que os valores de refletância medidos em laboratórios nos corpos-de-prova de telhas de fibrocimento pintados com as tintas do estudo não foram compatíveis com os resultados de temperaturas obtidos em campo.

Esta incompatibilidade de resultados de temperaturas superficiais em campo com a refletância medida em laboratório foram provavelmente devido ao dimensionamento inadequado dos protótipos expostos à radiação solar. A área interna do protótipo foi mal dimensionada, por isso a temperatura medida pelo termopar colocado na superfície e embaixo da telha não correspondia a real temperatura de cobertura residencial, por exemplo.

Como não havia ventilação dentro do protótipo, o ar se aquecia e ocorria 0 aumento da temperatura na sua área interna. Devido à transferência de calor por convecção ocorreu uma alteração da medição do termopar, por isso não foram apresentadas as curvas de temperatura dos termopares embaixo da cobertura (TI) e do interior (TA) do protótipo.

Os resultados de medição da temperatura pela exposição à radiação infravermelha obtida por lâmpadas foram importantes para determinação de parâmetros para a realização de uma exposição à radiação solar, tais como: 
- Isolação adequada do termopar colocado na superfície do material que recebe diretamente a radiação solar.

- Necessidade de uma janela nas paredes ou ático na cobertura dos protótipos.

- Construção de protótipos em escala real.

\subsection{Avaliação com base nos critérios da "Energy Star ${ }^{\circledR}$ Roofs Products"}

Para qualificar uma tinta como refletiva, a "Energy Star ${ }^{\circledR}$ Roofs Products" têm como critério valores iniciais de refletância. A refletância deve ser medida de acordo com a ASTM E 903-96 e seu resultado deve ser igual ou superior a $65 \%$ em relação ao espectro solar.

\subsubsection{Películas de tinta isoladas $x$ corpos-de-prova pintados}

Na Figura 5.32 é apresentado um gráfico comparativo da refletância das películas isoladas das tintas do estudo.

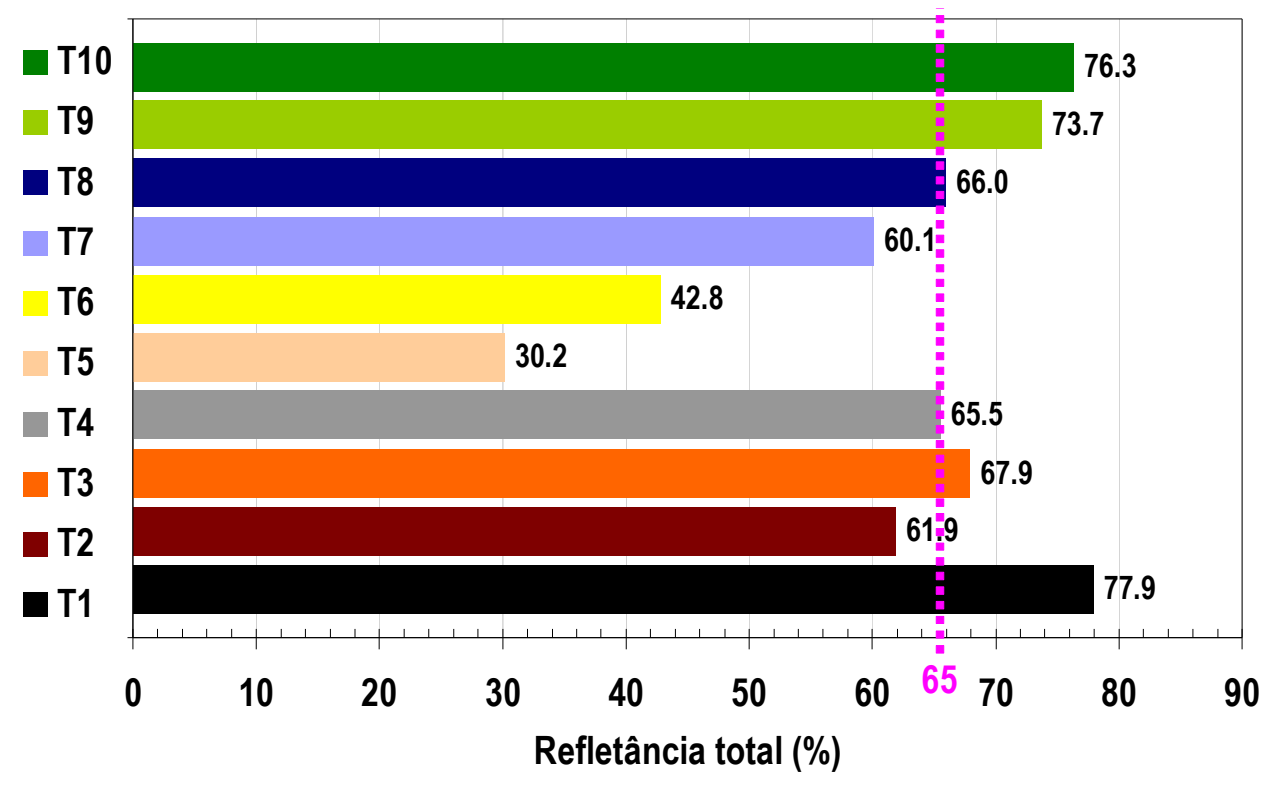

Figura 5.32: Gráfico comparativo da refletância das películas das tintas do estudo.

De acordo com os resultados de refletância das tintas refletivas do estudo, somente as tintas T2 (refletiva marrom) e T7 (alumínio nacional) obtiveram valores de refletância inferiores aos limites 
especificados pela Energy Star. As demais tintas refletivas obtiveram os valores de refletância dentro do estabelecido para materiais refletivos.

Na Figura 5.33 são apresentados os valores de refletância dos corpos-de-prova de fibrocimento pintados com as tintas do estudo.

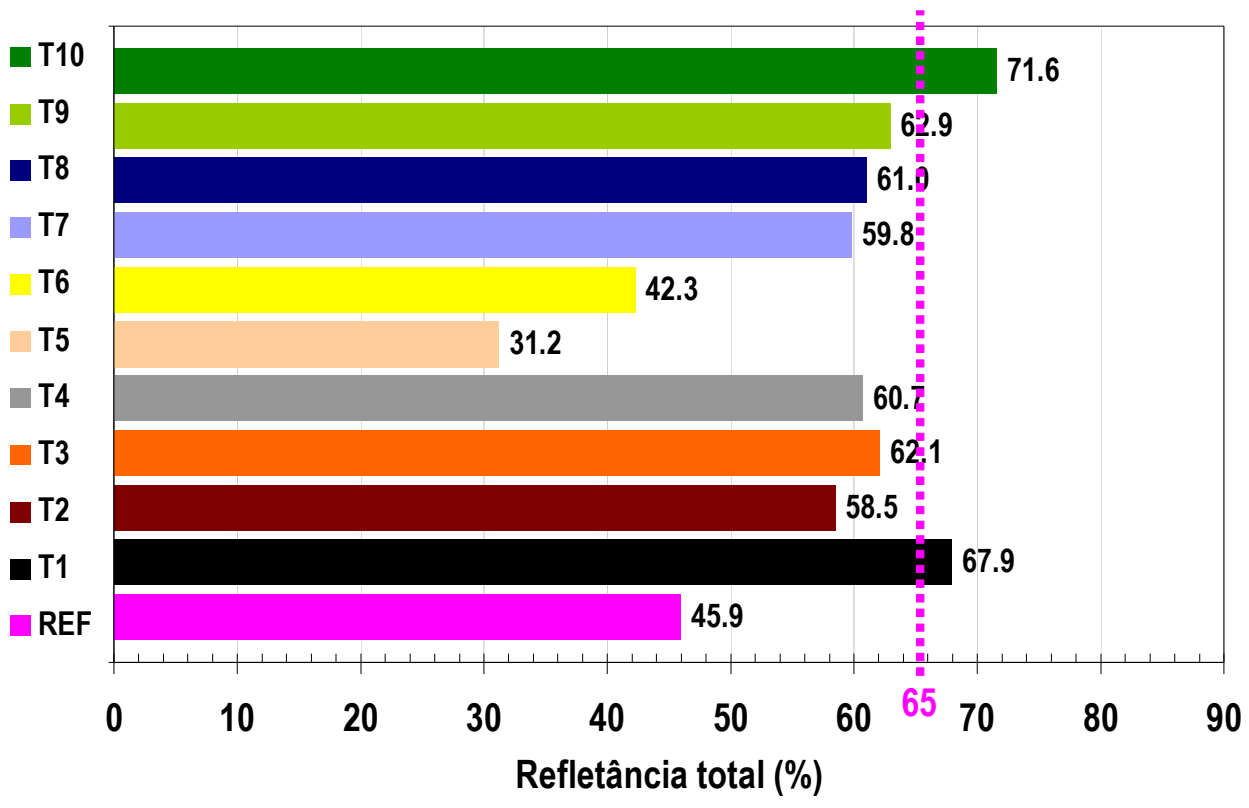

Figura 5.33: Gráfico comparativo da telha de fibrocimento pintada com as tintas do estudo.

Observa-se que somente a T10 (tinta refletiva com microesferas cerâmicas) e a T1 (tinta refletiva branca) obtiveram os valores de refletância dentro do estabelecido pela Energy Star.

Embora as demais tintas do estudo não tenham atingido o valor mínimo especificado, a aplicação das tintas nas telhas de fibrocimento, melhorou a refletância do sistema telha-tinta, com exceção das tintas convencionais de cor marrom (T5) e amarela (T6). A refletância dos corpos-de-prova de fibrocimento pintados diminuiu com relação as películas de tinta isolada, esta diferença de refletância pode ter sido causada pela irregularidade da superfície da telha de fibrocimento. 


\section{ConcLusão}

\subsection{Conclusão do trabalho}

Conforme apresentado na revisão da literatura, as modificações climáticas interferem diretamente no modo de vida das pessoas. Existem várias estratégias para melhorar o conforto térmico dos usuários no interior das habitações, sem comprometer o aspecto estético das construções.

Neste trabalho as tintas refletivas, formuladas com pigmentos refletivos cerâmicos, foram avaliadas comparativamente com tintas convencionais de cores correspondentes, através do estudo da refletância e da análise da sua influência no comportamento térmico da telha de fibrocimento.

As tintas refletivas coloridas apresentaram uma correlação de cores com as tintas convencionais. Ambas se diferem somente na refletância à radiação infravermelha, onde as tintas refletivas apresentam refletância elevada. Este fato comprova que a característica de apresentar cores claras, não é um indicativo de que a tinta apresenta uma alta refletância à radiação solar.

A avaliação da refletância de uma pintura não pode ser feita somente pela sua cor e 0 seu aspecto visual, pois uma tinta de cor escura e sem brilho, pode apresentar elevada refletância à radiação infravermelha e melhorar o comportamento térmico do material que recebeu a sua pintura.

O estudo da refletância com a utilização do espectrofotômetro com esfera integradora, paralelamente com o estudo do comportamento térmico (por radiação infravermelha simulada e exposição à radiação solar) podem contribuir para os estudos da influência das propriedades radiantes nos materiais e componentes construtivos. 
O uso da tinta convencional, com exceção da tinta branca, não se mostrou eficaz na diminuição da temperatura superficial da telha de fibrocimento e na melhoria do conforto térmico. As tintas refletivas coloridas apresentaram resultados satisfatórios, mas não significativos na diminuição da temperatura da telha de fibrocimento, devido ao dimensionamento dos protótipos do estudo.

O objetivo deste estudo de correlacionar a refletância com o comportamento térmico de tintas refletivas e convencionais foi comprovado através da medição da refletância e a sua influência na temperatura superficial dos materiais.

A influência da refletância no conforto térmico depende do calor que é transferido para o interior das edificações. Na tentativa de estudar o comportamento térmico destas tintas foram construídos protótipos em escala reduzida, que não reproduziram as temperaturas reais devido a sua dimensão e do tipo de material empregado. Como a madeira é um isolante térmico o calor ficou concentrado no interior do protótipo aumentando a temperatura medida pelo termopar no inferior da cobertura. Devido a essa condição, as temperaturas no interior dos protótipos não puderam ser apresentadas para provar que a refletância medida em laboratório realmente influencia no comportamento térmico.

A eficácia da refletância à radiação infravermelha das tintas refletivas comprovada neste estudo, pode ser incorporada pela indústria de materiais de construção civil, não só a indústria de tintas, mas também fabricantes de telhas para cobertura.

\subsection{Continuidade do trabalho}

Para uma análise completa deste tipo de tinta refletiva ainda é preciso uma continuação do estudo. Na exposição ao ambiente natural, as dimensões dos protótipos influenciaram na temperatura do seu interior, não tornando possível uma correlação com a temperatura superficial das coberturas. Há a necessidade de realizar este ensaio com um protótipo com maior dimensão 
para melhorar a reprodução das condições reais de exposição.

São necessários estudos de durabilidade destes materiais para a análise da sua refletância ao longo do tempo, da ação das intempéries nas coberturas, da pegajosidade da tinta e da deposição de partículas poluentes, que podem prejudicar o seu desempenho térmico.

A criação de metodologias, normalizações e critérios para caracterizar os "materiais frios" é importante para disseminação coletiva da utilização destes materiais, visando uma melhoria do nosso conforto térmico, a economia de energia e a preservação dos recursos naturais para as gerações futuras. 


\section{ReferÊnCIAS BIBLIOGRÁFICAS}

AKUTSU, M. Natureza do Trabalho: Avaliação do desempenho térmico de tinta aplicada em telhado. Relatório Técnico $n^{\circ} 36.823$ - Instituto de Pesquisas Tecnológicas (IPT). São Paulo, 1997.

AKUTSU, M. et al. Dados climáticos da cidade de São Paulo: variações nos últimos anos. VI Encontro Nacional e III Encontro Latino-Americano sobre Conforto no Ambiente Construído. São Pedro, 2001.

AL-HOMOUD, M. S. Performance characteristics and practical applications of common building thermal insulation materials. Building and Environment v. 40 p. 353-366, 2005.

ALMEIDA, R. N., ANDRADE, M. C. Síntese de pigmentos cerâmicos por precipitação homogênea e heterogênea. XIII Jornada de Iniciação Científica - CETEM, Fortaleza - 2005.

AMARILLA, V. L. M., SILVA FILHO, J. L., CARBONO, G. R. Substituição de resinas base solvente por resina base água. $7^{\circ}$ Congresso Internacional de Tintas, Anais. São Paulo, 2001.

ANDRADE, C. T. Definições básicas de termos relacionados a polímeros. Tradução de Compendium of Macromolecular Nomenclature (1974) aprovada pelo Comitê Brasileiro para Assuntos de Química junto à IUPAC, publicado em 1995.

ARMELIN, H. S.; CHERRY, N. Avaliação do uso e desempenho de barreiras de radiação térmica na construção civil. e-Mat - Revista de Ciência e Tecnologia de Materiais de Construção Civil. Vol. 1, n¹, p. 79-82, Maio 2004.

ASSIS, W. A.; ALMEIDA, G. Pigmentos Inorgânicos. In: FAZENDA, J. M. R. Tintas e Vernizes Ciência \& Tecnologia, Capítulo 10, $3^{\circ}$ Edição, 2005. 
ASSOCIAÇÃO BRASILEIRA DE NORMAS TÉCNICAS. NBR 15220-1: Desempenho térmico de edificações - Parte 1: Definições, símbolos e unidades. ABNT/CB-02 CONSTRUÇÃO CIVIL, 2005.

ASSOCIAÇÃO BRASILEIRA DE NORMAS TÉCNICAS. NBR 15077: Método para avaliação de desempenho de tintas para edificações não industriais - determinação da cor e da diferença de cor por medida instrumental. ABNT/CB-02 CONSTRUÇÃO CIVIL, 2004.

ASSOCIAÇÃO BRASILEIRA DE NORMAS TÉCNICAS. NBR 15299: Tintas para construção civil - Método para avaliação de desempenho e tintas para edificações não industriais determinação de brilho. ABNT/CB-02 CONSTRUÇÃO CIVIL, 2004.

American Society for Testing and Materials - ASTM INTERNATIONAL. ASTM-E903(96): Standard test method for solar absorptance, reflectance, and transmittance of materials using integrating spheres.

BASSO, A.; LUCINI, H. C.; RORIZ, M. Desempenho térmico de coberturas para edifícios habitacionais. In: Encontro Nacional de Conforto no Ambiente Construído. Brasil - Porto Alegre, RS. 1991. p. 15-20.

BEELER, R.; KURZ, G. Dióxido de titânio - 0 pigmento branco e suas funções. $3^{\circ}$ Congresso Internacional de Tintas. Vol. 1, p. 379-388, 1993.

BRETZ, S.; AKBARI, H. Long-term performance of high-albedo roof coatings. Energy and Buildings, v. 23, p. 159-167, 1997.

BRETZ, S.; AKBARI, H.; ROSENFELD, A. pratical issues for using solar-reflective materials to mitigate urban heat islands. Atmospheric Environment vol. 32, n¹, pág. $95-101$ (1997). 
CARVALHO, S., NOGUEIRA, J. L. As características das tintas e as características dos polímeros com que são formuladas. Boletim da Sociedade Portuguesa de Química, n95, 2005.

CAMARGO, M. G. P.; SATO, N. M. N.; PRADO, R. T. A. Estudo comparativo do desempenho térmico de protótipos com e sem utilização de barreiras de radiação na cobertura. IX Encontro Nacional e V Latino Americano de Conforto no Ambiente Construído - Ouro Preto, 2007.

CASTRO, A. P. A. S. Análise da refletância de cores de tintas através da técnica espectrofotométrica. Dissertação de mestrado pela Universidade Estadual de Campinas Faculdade de Engenharia Civil, 2005.

CASTRO, A. P. A. S et al. Medidas de refletância de cores de tintas através de análise espectral. Ambiente Construído, Porto Alegre, v. 3, n. 2, p. 69-73, abr.jun. 2003.

CASTRO, A. P. A. S. et al. Refletância de cores para pintura externa em função das regiões do espectro solar. Anais Encac - Cotedi. Curitiba 2003a.

CAVALCANTI, J. R. S. Estudo experimental comparativo entre resfriamento evaporativo e radiativo em ambientes cobertos com telhas de fibrocimento em região de clima quente e úmido. Dissertação de mestrado pela Universidade de São Paulo - Escola Politécnica da USP Departamento de Construção Civil, São Paulo, 2001.

CHAGAS, G. Ilhas de calor. Jornal Unesp n²03, Ano XIX, 2005.

CEBALLOS, J. C. Estimativa de radiação solar à superfície com céu claro: um modelo simplificado. Revista Brasileira de Meteorologia. V. 15, 113-122, 2000.

COLLADOS, E.; SÁNCHEZ, R. Global radiation, energy budget and heat island mitigation in 
Santiago de Chile. PLEA 2003 - The 20th Conference on Passive an Low Energy Architecture. Santiago do Chile, nov. 2003.

COSTA, E. C. Capítulo 6: transmissão de calor. In: COSTA, E. C. Física aplicada à construção: conforto térmico, $4^{\circ}$ edição, 1991.

COSTA, F. P. S. Evolução urbana e da cobertura vegetal de Piracicaba - SP (1940-2000). Dissertação de mestrado pela Escola Superior de Agricultura Luiz de Queiroz, 84 p. Piracicaba, 2004.

DUFFIE, J. A.; BECKMAN, W. A. "Solar engineering of thermal processes", John Wiley \& Sons, Inc. New York, 1991.

FASANO, C. A. T. V. Tintas: Métodos de controle de pinturas e superfícies. Ed. Hemus. $4^{\circ}$ Edição, 1995.

FARKAS, C. Apostila do curso sobre tecnologia instrumental em colorimetria e aparência. Tecnocolor, São Paulo, 2001.

FAZENDA, J. M. R. Tintas e vernizes: ciência e tecnologia. $3^{\circ}$ Edição - Editora Edgard Blücher, 2005.

FAZENDA, J. M. R.; DINIZ, F. D. Introdução, história e composição básica. In: FAZENDA, J. M. R. Tintas e Vernizes - Ciência \& Tecnologia, Capítulo 1:, $3^{\circ}$ Edição, 2005.

FERREIRA, F. L. S. Medição da refletância e análise de sua influência na temperatura superficial dos materiais utilizados em coberturas de edifícios. Dissertação de mestrado pela Universidade de São Paulo - Departamento de Construção Civil, São Paulo, 2003.

FERREIRA, F. L. S.; PRADO, R. T. A. Medição da refletância ou refletância dos materiais 
utilizados em coberturas de edifícios no Brasil. Anais Encac - Cotedi. Curitiba 2003.

GITIDHARAN, R.; LAU, S. S. Y.; GANESAN, S. Nocturnal heat island effect in urban residencial develpments of Hong Kong. Energy and Buildings 37, p. 964-971, 2005.

GUITIÁN, R. Evolução dos conceitos de polímeros e de polimerização. Revista Química e Derivados, n³21, p. 32-40, outubro, 1994.

HIEN, W. N.; YU, C. Study of urban heat island in singapure. PLEA 2003 - The $20^{\text {th }}$ Conference on Passive an Low Energy Architecture. Santiago do Chile, nov. 2003.

HUNG, T.; UCHIHAMA, D.; OCHI, S.; YASHIFUMI, Y. Assessment with satellite data of the urban heat island effects in Asia mega cities. International Journal of Applied Earth Observation and Geoinformation 8 p. 34-48 (2006).

IKEMATSU, P.; UEMOTO, K. L.; SATO, N. M. N. Medição da refletância por espectrofotometria: aplicação na avaliação comparativa de revestimentos refletivos nacionais e internacionais. Conferência Brasileira sobre Materiais e Tecnologias Não-Convencionais na Construção Ecológica e Sustentável - Brasil-NOCMAT. Salvador, 2006.

JAHNKE, K. A.,et al. Reutilização de embalagem tipo longa vida como barreira radiante em painel de vedação. XI Encontro Nacional de Tecnologia no Ambiente Construído, Florianópolis, 2006.

KAIRALLA, R. B. Princípios de formulação. In: FAZENDA, J. M. R. Tintas e Vernizes - Ciência \& Tecnologia, Capítulo 16:, $3^{\circ}$ Edição, 2005.

KOLOKOTRONI, M.; GIANNITSARIS, I.; WATKINS. R. The effect of the London urban heat island on building summer cooling demand and night ventilation strategies. Solar Energy, 2006. 
LEE, D.; PHILLIPS, D. Color, pigments, colorants and color system in coatings applications. $9^{\circ}$ Congresso Internacional de Tintas. São Paulo, 2005.

LEVINSON, R.; AKBARI, H.; KOMOPACKI, S.; BRETZ, S. Inclusion of cool roofs in nonresidential Title 24 prescriptive requirements. Energy Policy 33 p. 151-170 (2005).

LEVINSON, R.; BERDAHL, P.; ALBARI, H. Solar spectral optical properties of pigments - Part I: model for deriving scattering and absorption coefficients from transmittance and reflectance measurements. Solar Energy Materials \& Solar Cells, n89, p. 319-349, 2005.

LEVINSON, R., AKBARI, H., REILLY, J. Cooler tile-roofed buildings with near-infrared-reflective non-white coatings. Building and Environment, vol. 2, issue 7, 2007.

LIVADA, I.; SANTAMOURIS, M.; NIACHOU, K.; PAPANIKOLAOU, N.; MIKALAKAKOU, G. The thermal island effect in the extended region of Athens. Theoretical and applied climatology 71 , p. 219-230, 2002.

LUTGENS, F.K.; E.J. TARBUCK, The Atmosphere: an introduction to Meteorology. Prentice Hall, 1989.

LUXMOORE, D. A.; JAYASINGHE, M. T. R.; MAHENDRAN, M. Mitigating temperature increases in high lot density sub-tropical residential developments. Energy and Buildings, 37 p. 1212-1224 (2005).

MANSHAUSEN, P. Role and function of rheological additives in modern emulsion paints and industrial coatings. ANAIS - $7^{\circ}$ Congresso Internacional de Tintas, pág. 63 - 74. São Paulo, 2001.

MARTINAZZO, C. A. Modelos de estimativa de radiação solar para elaboração de mapas 
soliméricos. Dissertação de mestrado pela Universidade Federal do Rio Grande do Sul, Departamento de Engenharia Mecânica. Porto Alegre, 2004.

MICHELS, C. Análise da transferência de calor em coberturas com barreiras radiantes. Dissertação de mestrado pela Universidade Federal de Santa Catarina, Centro tecnológico programa de pós-graduação em engenharia civil. Florianópolis, 2007.

MICKELS, C.; LAMBERTS, R.; GUTHS, S. Avaliação da redução no fluxo de calor proporcionada pelo uso de barreiras radiantes em cobertura. XI Encontro Nacional de Tecnologia no Ambiente Construído, Florianópolis, 2006.

MIHALAKAKOU, G.; FLOCAS, H.; SANTAMOURIS, M.; HELMIS, C. The impacto f synoptic scale atmospheric circulation on the urban hat island efect over Athens, Greece. Journal of Applied Meteorology, 41 (5), p. 519-527, 2002.

NIXON, J. D. The temperature of color. Metalmag mai/jun, 2002.

OUCHI, J. T. Fundamentos de colorimetria. In: FAZENDA, J. M. R. Tintas e Vernizes - Ciência \& Tecnologia, Capítulo 12: Colorimetria, $3^{\circ}$ Edição, 2005.

PAIVA, A. Quanto mais quente pior. Revista Nexo, p. 36 a 38, setembro 2003.

PAULA, R. Z. R. A influência da vegetação no conforto térmico do ambiente construído. Dissertação de Mestrado pela Universidade de Campinas - Faculdade de Engenharia Civil, Arquitetura e Urbanismo, 2005.

RODOLFO JR.; et al. Tecnologia do PVC. São Paulo: ProEditores/Braskem, 400p., 2002.

RODRIGUES, P. Manual de iluminação eficiente. Procel, $1^{\circ}$ Edição, julho, 2002). 
RORIZ, V. R., DORNELLES, K. D., RORIZ, M. Fatores determinantes da absortância solar de superfícies opacas. IX Encontro Nacional e V Latino Americano de Conforto no Ambiente Construído - Ouro Preto, 2007

ROSENFELD, A. H.; et al. Mitigation of urban heat islands: materials, utility programs, updates. Energy and Buildings 22 (1995) p.255-265.

ROSENZWEIG, C.; SOLECKI, W.D.; PARSHALL, L.; CHOPPING, M.; POPE, G.; GOLDBERG, R. Characterizing the urban heat island in current and future climates in New Jersey. Environmental Hazards 6, p. 51-62, 2005.

SAILOR, D. J.; RESH, K.; SEGURA, D. Field measurement of albedo for limited extent test surfaces. Solar Energy 80 P. 589-599, 2006.

SANTAMOURIS, M. Energy and climate in then urban build environment. James and James Science Publishers, London, 2001.

SANTAMOURIS, M.; MIHALAKAKOU, G.; PAPANIKOLAOU, N. ASSISNAKOPOLOUS, D., N. A neural network approach for modelling the heat island phenomenon in urban areas during the summer period. Geophysics Research Letters, 26(3), p. 337-340, 1999.

SPENGEMAN, W. F. Chapter 2.8 - Pigments. In: KOLESKE, J. V. Paint and coatings testing manual, ASTM, 1995.

SILVA, A. R.; et al. Identificação e quantificação de resinas, cargas e pigmentos em tintas látex branca. Revista Eclética Química, vol. 25, São Paulo, 2000.

SILVA, J. M. Caracterização de tintas látex para construção civil: diagnóstico para o mercado de São Paulo. Dissertação de Mestrado pela Escola Politécnica da Universidade de São Paulo - 
Departamento de Construção Civil. 222 p., São Paulo, 2005.

SIMIONI, W. I.; CLEZAR, C. A. Desempenho térmico de coberturas: uma análise utilizando diferenças finitas. Anais Encac - Cotedi. Curitiba 2003.

SIMPSON, J.R; McPHERSON, E.G. The effects of roof albedo modification on cooling loads of scale model residences in Tucson, Arizona. Energy and Buildings 25 (1997) 127-137.

SIQUEIRA, T. C. P. A., AKUTSU, M., LOPES, J. I. E., SOUZA, H. E. Dados Climáticos para avaliação do desempenho térmico de edificações. Esc. Minas, Ouro Preto, 58(2): 133-138, abr. jun. 2005

SMITH, G. B., GENTLE, A. P. SWIFT, EARP, A., MRONGA, N. Coloured paints based on coated flakes of metal as the pigment, for enhanced solar reflectance and cooler interiors: description and theory. Solar Energy Materials \& Solar Cells 79 (2003) 163-177.

SOARES, A. Ilhas de calor fazem temperatura variar até 12 graus dentro de SP. 0 Estado de São Paulo. São Paulo, 09 de setembro de 2007 - Caderno Metrópole, pág. C4.

SOLECKI, W. D. et al. Mitigation of the heat island effect in urban Neew Jersey. Environmental Hazards 6 (2005) 39-49.

SOUZA, H. A.; PINTO, M. A. V.; NETO, A. H.; TRIBESS, A. Avaliação do desempenho de coberturas em habitações populares feitas em estrutura metálica. VI Encontro Nacional e III Encontro Latino-Americano sobre Conforto no Ambiente Construído - Anais. São Paulo, 2001.

STURDEVANT, N. Reflective roofs return multiple dividends. Building Operating Management, maio 2000 . 
SYNNEFA, A., SANTAMOURIS, M., LIVADA, I. A study of the thermal performance of reflective coatings for the urban environment. Solar Energy, 2005.

SYNNEFA, A., SANTAMOURIS, M., APOSTOLAKIS, K. On the development, optical properties and thermal performance of cool colored coatings for the urban environment. Solar Energy, 2006.

TATUM, R. Cool Roofs, hot topic. Building operating management, maio 1999.

THEVENARD, D., HADDAD, K. Ground reflectivity in the context of building energy simulation. Energy and Buildings, 38, p. 972-980, 2006.

UEMOTO, K. L. Influência da formulação das tintas de base acrílica como barreira contra a penetração de agentes agressivos nos concretos. Tese de Doutorado pela Escola Politécnica da Universidade de São Paulo - Departamento de Construção Civil. 178p., São Paulo, 1998.

UEMOTO, K. L. Tinta látex acrílica para construção civil: influência da formulação na microestrutura e nas propriedades de suas películas. Projeto FAPESP, Processo: 99/12986-9, Relatório Final. São Paulo, 2002.

UEMOTO, K. L. Pintura, execução e inspeção de pinturas. Coleção primeiros passos da qualidade no canteiro de obras. São Paulo, 2002a.

VALENTINI, J. Desempenho térmico: coberturas de fibrocimento. Simpósio Latino-americano de Racionalização da Construção e a Aplicação às habilitações de Interesse social - Artigo técnico. São Paulo, 1981.

VELAZQUEZ-LOZADA, A.; GONZALEZ, J. E.; WINTER, A. Urban heat island effect análisis for San Juan, Puerto Rico. Atmosferic Environment 40, p. 1731-1741, 2006. 
VENÂNCIO, M. et al. A expansão urbana e os problemas sócio-ambientais no entorno de catalão/go. VI Congresso Brasileiro de Geógrafos (VI CBG), 18 a 23 de julho de 2004. Goiânia - GO Disponível em: http://www.cibergeo.org/agbnacional/VICBG-2004/. Acesso em 17.09.2004.

VINK, P. et al. UV stability of water-borne acrylic coating. Polymer Degradation and Stability. V48, p. 155-60, 1995.

VITTORINO, F., SATO, N. M. N., AKUTSU, M. Desempenho térmico de isolantes refletivos e barreiras radiantes aplicados em coberturas. ENCAC - COTEDI, Curitiba, 2003.

ZORZETTO, R. A cidade de 77 climas. Revista Pesquisa FAPESP, ed. 96, fevereiro, 2004. 